\title{
Hydrogeologic, Geophysical, Water-Quality, Transient-Tracer, and Flow-Model Analysis of the Ground-Water Flow System near Dillon, Montana
}

Water-Resources Investigations Report 98-4250 

U.S. Department of the Interior

U.S. Geological Survey

Hydrogeologic, Geophysical, Water-Quality, TransientTracer, and Flow-Model Analysis of the Ground-Water Flow System near Dillon, Montana.

By Daryll A. Pope, David W. Clark, Stephanie Dunkle Shapiro, and Sean M. Lawlor

Water-Resources Investigations Report 98-4250

In cooperation with the MONTANA DEPARTMENT OF NATURAL RESOURCES AND CONSERVATION 
U.S. Department of the Interior :

BRUCE BABBITT, Secretary

\section{U.S. Geological Survey}

Charles G. Groat, Director

Helena, Montana

April 1999

For additional information write to:

\section{- District Chief}

U.S. Geological Survey 3162 Bozeman Avenue

Helena, MT 59601

Copies of this report may be purchased from:

\section{U.S. Geological Survey}

Branch of Information Services

Box 25286

Denver, CO 80225-0286 


\section{CONTENTS}

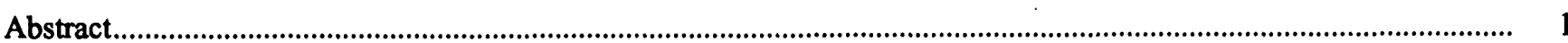

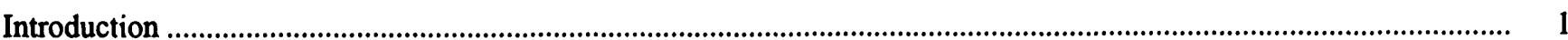

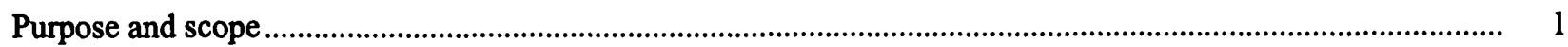

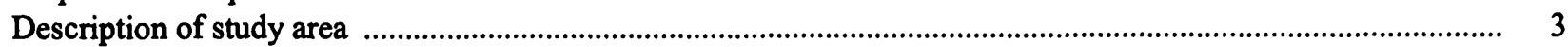

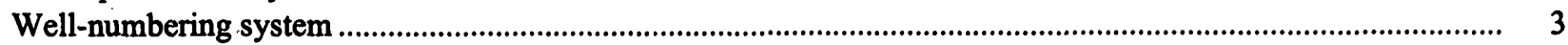

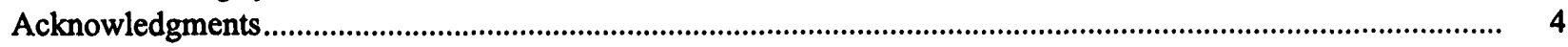

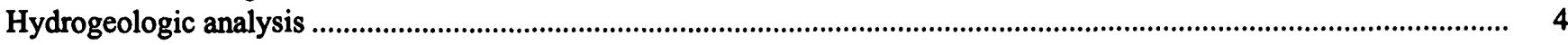

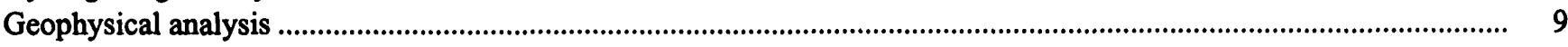

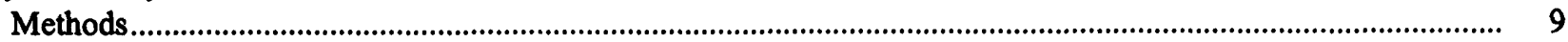

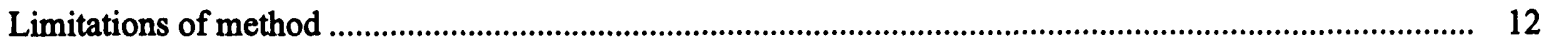

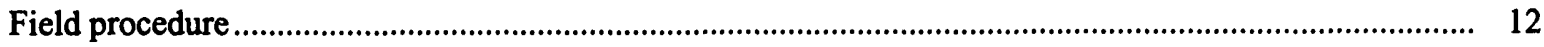

Results of the seismic-refraction surveys ............................................................................................ 18

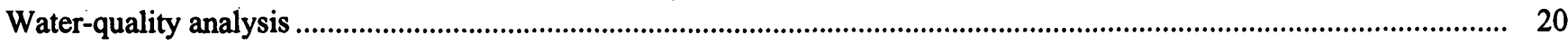

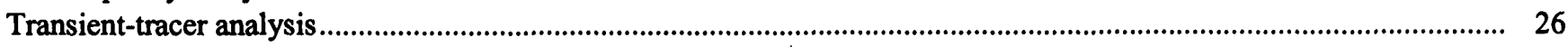

Chlorofluorocarbon (CFC) dating technique ................................................................................................ 26

Tritium and helium-isotope dating technique ..................................................................................................... 26

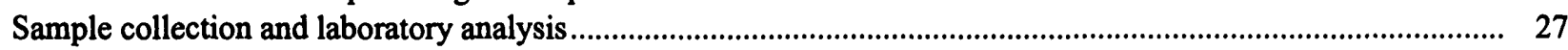

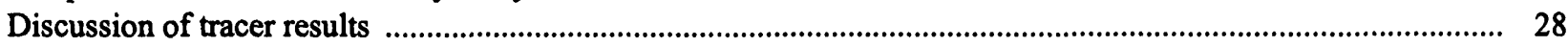

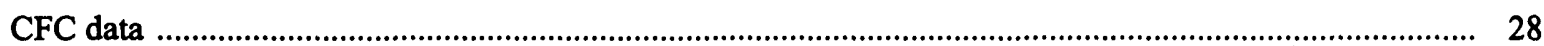

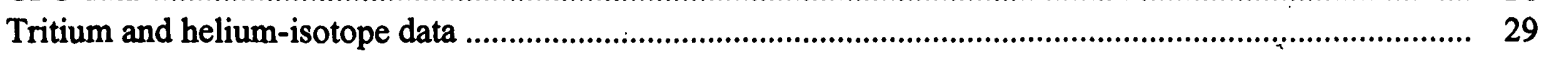

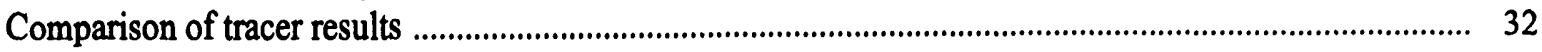

Discussion of tracers in relation to the flow system in the study area..................................................

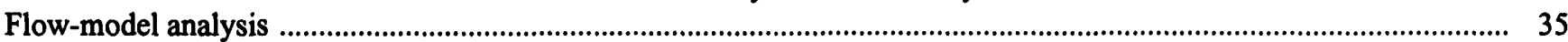

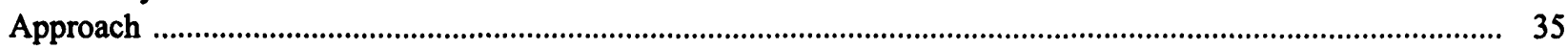

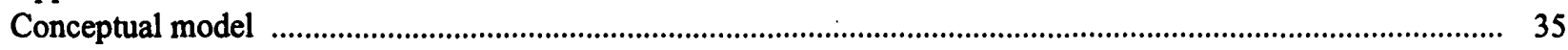

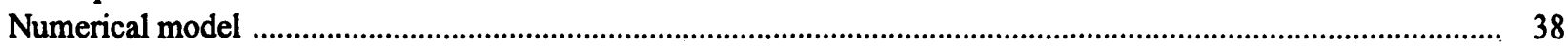

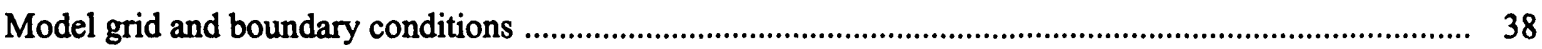

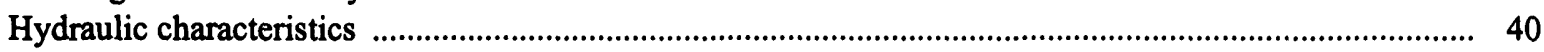

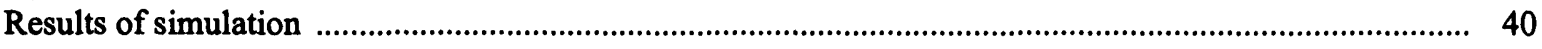

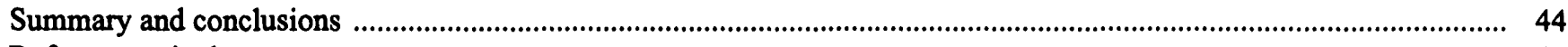

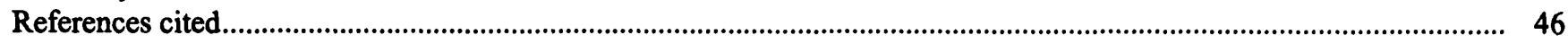

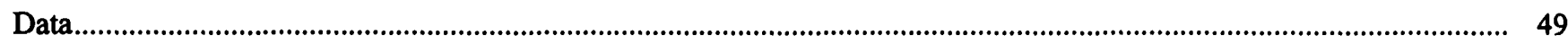

\section{ILLUSTRATIONS}

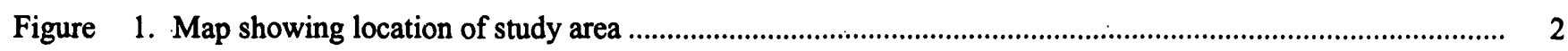

2. Diagram showing well-numbering system............................................................................................. 4

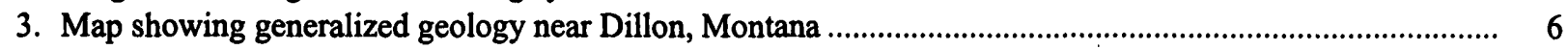

4. Map showing locations of wells, springs, and surface-water sites near Dillon, Montana .............................. 8

5. Hydrograph showing water level measurements in wells near Blacktail Deer Creek, and mean daily discharge at Blacktail Deer Creek near Dillon, Montana, for 1991-95

6. Map showing potentiometric surface of the basin-fill aquifer near Dillon, Montana, September 16, 1993

7. Map showing location of seismic-refraction profiles near Dillon, Montana

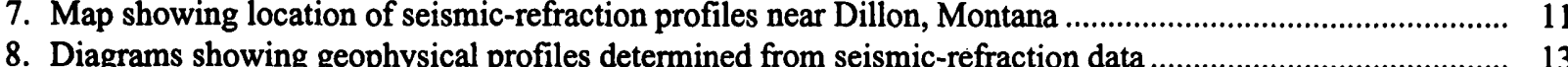

9. Map showing stiff diagrams for water samples collected from selected wells, springs, and surface-water sites near Dillon, Montana, 1991 and 1993-94 ................................................................ 22

10. Map showing lithium concentrations in water from wells, springs, and surface-water sites near Dillon, Montana.

11. Map showing strontium concentrations in water from wells, springs, and surface-water sites near Dillon, Montana . 


\section{ILLUSTRATIONS (Continued)}

Figure 12. Map showing barium concentrations in water from wells, springs, and surface-water sites near Dillon, Montana..

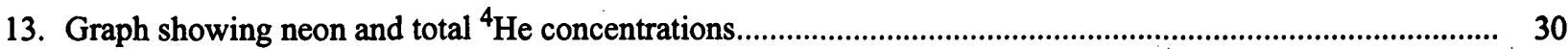

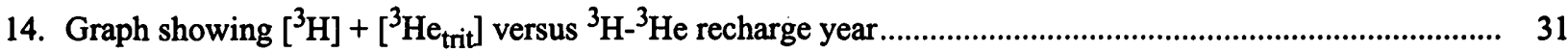

15. Graph showing mean apparent tracer ages compared to the CFC-12 mean apparent age ............................ 33

16. Map showing chlorofluorocarbon (CFC) apparent ages for samples near Dillon, Montana, 1991 and 1993-94

17. Diagram showing conceptual cross section along flow path, Blacktail Deer Creek valley, Montana ............. 36

18. Hydrograph showing water levels measured in wells located along the Blacktail Deer Creek valley near Dillon, Montana, from 1993-95.

19. Diagram showing model grid, layers, and boundary conditions

20. Diagram showing simulated potentiometric surface and travel times for the basic simulation and CFC-12 mean apparent ages and water levels measured September 16, 1993, Blacktail Deer Creek valley, Montana.

21. Diagram showing simulated potentiometric surface and travel times for the simulation, including irrigation withdrawals and irrigation recharge, and CFC- 12 mean apparent ages and water levels measured September 16, 1993, Blacktail Deer Creek valley, Montana

TABLES

Table 1. Records of selected wells located in the lower Blacktail Deer Creek area near Dillon, Montana

2. Selected springs and surface-water sites sampled in the lower Blacktail Deer Creek area near Dillon, Montana

3. Average compressional velocities of sound for various earth materials in the lower Blacktail Deer Creek, lower Beaverhead River, and lower Rattlesnake Creek valley near Dillon, Montana

4. Physical characteristics, inorganic constituents, and trace elements in ground- and surface-water samples collected by the U.S. Geological Survey in the lower Blacktail Deer Creek area near Dillon, Montana, 1991 and 1993-94...

5. Physical characteristics, inorganic constituents, and trace elements in ground- and surface-water samples collected by the University of Montana in the lower Blacktail Deer Creek area near Dillon, Montana, 1993

6. Chlorofluorocarbon (CFC) data for the lower Blacktail Deer Creek area near Dillon, Montana, 1993-94 ...... 63

7. Physical characteristics measured in wells, springs, and surface-water sites during chlorofluorocarbon (CFC) sampling in the lower Blacktail Deer Creek area near Dillon, Montana, 1991 and 1993-94

8. Results of tritium, helium isotope, and neon analyses for the lower Blacktail Deer Creek and Beaverhead River valleys near Dillon, Montana, August 1994.

9. Hydraulic characteristics determined in wells located along line of section $\mathrm{K}-\mathrm{K}$ ' in the lower Blacktail Deer Creek valley, Montana

10. Comparison of travel times of water particles determined from model simulations and ages determined using the tracer dichlorodifluoromethane (CFC-12) along a flow path in the Blacktail Deer Creek valley, Montana . 


\begin{tabular}{|c|c|c|}
\hline Multiply & By & To obtain \\
\hline \multicolumn{3}{|c|}{ Length } \\
\hline inch (in.) & 25.4 & millimeter \\
\hline foot $(\mathrm{ft})$ & 0.3048 & meter $(\mathrm{m})$ \\
\hline mile (mi) & 1.609 & kilometer \\
\hline \multicolumn{3}{|c|}{ Area } \\
\hline acre & 4,047 & square meter \\
\hline square foot $\left(\mathrm{ft}^{2}\right)$ & $\begin{array}{l}0.09290 \\
\text { Volume }\end{array}$ & square meter \\
\hline gallon (gal) & 3.785 & liter \\
\hline gallon (gal) & 0.003785 & cubic meter \\
\hline cubic foot $\left(\mathrm{ft}^{3}\right)$ & 0.028317 & cubic meter \\
\hline \multicolumn{3}{|c|}{ Elow rate } \\
\hline foot per second $(\mathrm{ft} / \mathrm{s})$ & 0.3048 & meter per second \\
\hline foot per day $(\mathrm{ft} / \mathrm{d})$ & 0.3048 & meter per day \\
\hline cubic foot per second $\left(\mathrm{ft}^{3} / \mathrm{s}\right)$ & 0.028317 & cubic meter per second \\
\hline cubic foot per day $\left(\mathrm{ft}^{3} / \mathrm{d}\right)$ & 0.028317 & cubic meter per day \\
\hline gallon per minute (gal $/ \mathrm{min})$ & 0.06309 & liter per second \\
\hline gallon per day (gal/d) & 0.003785 & cubic meter per day \\
\hline inch per year (in/yr) & 25.4 & millimeter per year \\
\hline \multicolumn{3}{|c|}{ Specific capacity } \\
\hline gallon per minute per foot $[(\mathrm{gal} / \mathrm{min}) / \mathrm{ft}]$ & 0.207 & liter per second per meter \\
\hline \multicolumn{3}{|c|}{ Hydraulic conductivity } \\
\hline foot per day (ft/d) & 0.3048 & meter per day \\
\hline \multicolumn{3}{|c|}{ Transmissivity } \\
\hline foot squared per day $\left(\mathrm{ft}^{2} / \mathrm{d}\right)$ & 0.0929 & meter squared per day \\
\hline
\end{tabular}

Degrees Celsius $\left({ }^{\circ} \mathrm{C}\right)$ may be converted to degrees Fahrenheit $\left({ }^{\circ} \mathrm{F}\right)$ by using the following equation:

$$
{ }^{\circ} \mathrm{F}=1.8\left({ }^{\circ} \mathrm{C}\right)+32
$$

Degrees Fahrenheit $\left({ }^{\circ} \mathrm{F}\right)$ may be converted to degrees Celsius $\left({ }^{\circ} \mathrm{C}\right)$ by using the following equation:

$$
{ }^{\circ} \mathrm{C}=\left({ }^{\circ} \mathrm{F}-32\right) / 1.8
$$

Sea level: In this report, "sea level" refers to the National Geodetic Vertical Datum of 1929 (NGVD of 1929)--a geodetic datum derived from a general adjustment of the first-order level nets of both the United States and Canada, formerly called Sea Level Datum of 1929.

Altitude, as used in this report, refers to distance above or below sea level.

Transmissivity: The standard unit for transmissivity is cubic foot per day per square foot times foot of aquifer thickness [( $\left.\left.\mathrm{ft}^{3} / \mathrm{d}\right) / \mathrm{ft}^{2}\right] \mathrm{ft}$. The mathematically reduced form, foot squared per day $\left(\mathrm{ft}^{2} / \mathrm{d}\right)$, is used for convenience.

Specific conductance is given in microsiemens per centimeter at 25 degrees Celsius $(\mu \mathrm{S} / \mathrm{cm})$.

Concentrations of chemical constituents in water are given either in milligrams per liter $(\mathrm{mg} / \mathrm{L})$ or micrograms per liter $(\mu \mathrm{g} / \mathrm{L})$.

Abbreviated water-quality units used in this report:

$\mu \mathrm{g} / \mathrm{L} \quad$ micrograms per liter

$\mu \mathrm{S} / \mathrm{cm} \quad$ microsiemens per centimeter at 25 degrees Celsius

$\mathrm{mg} / \mathrm{L} \quad$ milligrams per liter

pptv parts per trillion, (volume) 
TU

$\mathrm{pg} / \mathrm{kg}$

$\mathrm{pg} / \mathrm{L}$

tritium unit, $1 \mathrm{TU}=$ one atom of ${ }^{3} \mathrm{H}$ per $10^{18}$ atoms of hydrogen

picograms per kilogram

$\operatorname{ccSTP} g^{-1}$

picograms per liter

cubic centimeters per gram at standard temperature and pressure

Acronyms used in this report:

BOR

CFC

Bureau of Reclamation of the U.S. Department of the Interior

CFC-11

CFC-12

CFC-113

DNRC

MBMG

PVC

UM

chlorofluorocarbon

trichlorofluoromethane

dichlorodifluoromethane

trichlorotrifluoroethane

Montana Department of Natural Resources and Conservation

Montana Bureau of Mines and Geology

polyvinyl chloride

USGS

University of Montana

U.S. Geological Survey 


\title{
HYDROGEOLOGIC, GEOPHYSICAL, WATER-QUALITY, TRANSIENT-TRACER, AND FLOW-MODEL ANALYSIS OF THE GROUND-WATER FLOW SYSTEM NEAR DILLON, MONTANA
}

\author{
By Daryll A. Pope, David W. Clark, Stephanie Dunkle Shapiro, and Sean M. Lawlor
}

\section{Abstract}

This report describes the results of a study done in cooperation with the Montana Department of Natural Resources and Conservation of the ground-water. system in the basin-fill aquifer in the lower parts of Blacktail Deer Creek, Beaverhead River, and Rattlesnake Creek valleys near Dillon, Montana. Waterlevel, geophysical, and water-quality data, groundwater apparent age determinations using two transienttracer dating methods, and simulations made using a simple cross-sectional model were used to describe the ground-water system in the aquifer. Water levels in wells in the eastern part of the valley along the Blacktail Deer Creek had larger annual variations and reflected seasonal variations more strongly than wells located on the bench in the western part of the valley. Seismic-refraction profiling at 10 sites was used to differentiate between Quaternary and Tertiary sediments and to determine the depths to bedrock, where possible. Differences in water quality as indicated by major ions and trace elements existed between water samples of the shallow ground water near Blacktail Deer Creek in the eastern part of the valley and those from the bench in the western part of the valley. Apparent tracer ages determined for sites along Blacktail Deer Creek indicate a shallow ground-water flow system with local recharge and interactions with Blacktail Deer Creek. Wells in the western part of Blacktail Deer Creek valley are recharged by flow from the upland limestone bedrock, and water from these wells generally is much older than from wells along Blacktail Deer Creek. Water from a slough near the Beaverhead River was about 12 years old, indicating a relatively local source for the shallow ground water and the slough in the area. A cross-sectional ground-water flow model was developed to illustrate the key concepts affecting the groundwater flow system in the Blacktail Deer Creek valley.
An initial simulation matched measured hydraulic heads and flows but did not accurately represent the travel times of water in the flow system. A revised conceptual model was developed which included the effects of irrigation return flow. A simulation of this conceptual model reasonably matched the observed heads and flow rates and more accurately matched the travel times.

\section{INTRODUCTION}

Development in recent years of the ground-water resources in the basin-fill aquifer in the lower Blacktail Deer Creek, lower Beaverhead River, and lower Rattlesnake Creek valleys near Dillon, Montana, (fig. 1) has raised concerns about ground-water flow in the area. In particular, a concern has arisen that the increased use of ground water may decrease flow in the Beaverhead River and adjacent sloughs. Detailed information about the ground-water flow system in this area is needed to describe potential effects of increased ground-water use on the water resources of the area.

In 1991, the Montana Department of Natural Resources and Conservation (DNRC), in cooperation with the Bureau of Reclamation (BOR), began a study of the ground-water resources in the Beaverhead River valley near Dillon. In 1993-94, the U.S. Geological Survey (USGS), in cooperation with the DNRC, conducted a study to help provide additional information needed to describe the ground-water system in the lower Blacktail Deer Creek, lower Beaverhead River, and lower Rattlesnake Creek valleys near Dillon.

\section{Purpose and Scope}

The purpose of this report is describe the groundwater flow system in the basin-fill aquifer in the lower 


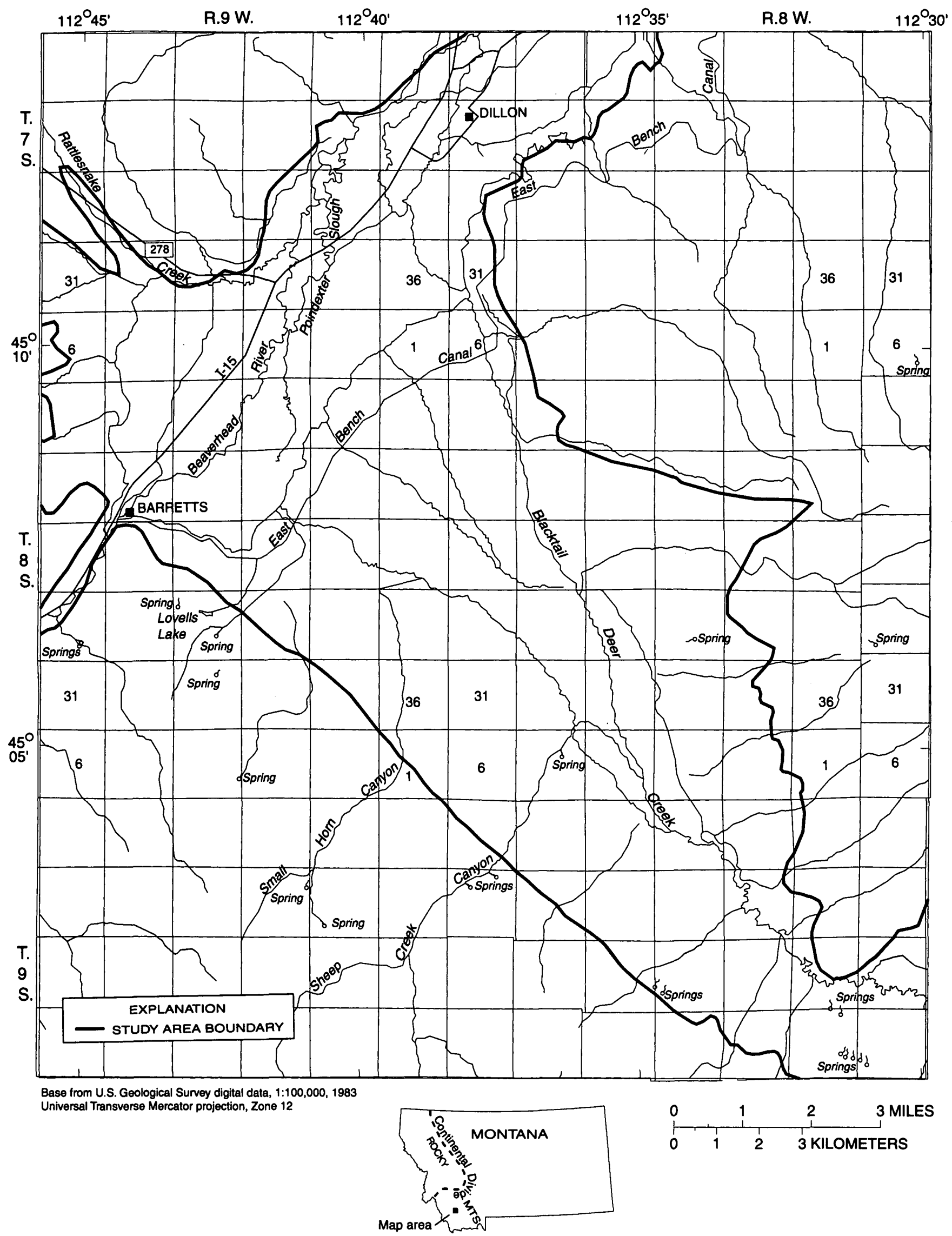

Figure 1. Location of study area. 
Blacktail Deer Creek, lower Beaverhead River, and lower Rattlesnake Creek valleys near Dillon. Specific objectives of this study, conducted during 1993-94, were to:

1. Describe the ground-water flow system in the basin-fill aquifer using water-level data,

2. Help to further define the hydrogeologic framework of the basin-fill aquifer using the geophysical technique, seismic refraction,

3. Differentiate sources of recharge to the aquifer based on water-quality data collected in the study area,

4. Determine the ages of ground water in the aquifer from samples collected from wells throughout the study area using chlorofluorocarbon (CFC) and tritium and helium isotope $\left({ }^{3} \mathrm{H}-{ }^{3} \mathrm{He}\right)$ dating techniques,

5. Develop a conceptual and numerical crosssectional ground-water flow model of the flow system along a designated flow path in the aquifer.

This report presents a general description of the study area. The generalized geology and the hydrogeology of the basin-fill aquifer is presented, along with a generalized geologic map of the area and a potentiometric-surface map based on water-level measurements collected September 16, 1993. Hydrographs of water levels in selected wells are used to describe seasonal water-level fluctuations. Ten geophysical profiles are presented from the seismic-refraction surveys. Water-quality data collected by the USGS and the University of Montana (UM) are presented in tables. Stiff diagrams indicating water type for selected water samples as well as illustrations showing trace-element concentrations for lithium, strontium, and barium in water samples are included. Transient-tracer analysis for $\mathrm{CFC}$ and ${ }^{3} \mathrm{H}-{ }^{3} \mathrm{He}$ dating techniques are discussed and the results are presented in tables and graphs. A figure showing the mean apparent ages of water as a result of CFC sampling in 1991 and 1993-94 is shown and discussed. Finally, a conceptual and numerical crosssectional ground-water flow model is presented that simulates flow along a designated flow path in the Blacktail Deer Creek valley. The results of two simulations are presented to show the basic flow system and the effects of irrigation withdrawal and recharge on the flow system. Ground-water travel times, determined by particle tracking, are compared to ground-water ages determined using the tracers.

\section{Description of Study Area}

The study area (fig. 1) includes a basin-fill aquifer consisting of unconsolidated and semi-consolidated deposits of Quaternary and Tertiary age in the Blacktail Deer Creek, lower Beaverhead River, and lower Rattlesnake Creek valleys near Dillon. About 4,000 people reside in the City of Dillon (U.S. Bureau of the Census, 1991). Residents in this area depend on municipal, community, or private wells to supply their drinking water. The municipal water supply for Dillon is obtained from wells completed in the basin-fill aquifer.

The climate of the area is typical of higher altitude intermontane basins of the Northern Rocky Mountains east of the Continental Divide, which is located about $50 \mathrm{mi}$ north and west of Dillon. The average annual precipitation at the Dillon airport (altitude 5,220 ft) was 10.21 in., and the average annual temperature was $42.9^{\circ} \mathrm{F}$ for the period 1961-90 (National Oceanic and Atmospheric Administration, 1992).

Land use in the Blacktail Deer Creek valley is mostly agricultural. The flood plains are used to grow irrigated hay and alfalfa. Both sprinkler and flood irrigation methods are used in the study area. The topographically higher terraces flanking the flood plains are used for dryland wheat farming and rangeland for livestock. Cattle grazing is the major land use in this area. Irrigation canals are used to divert surface water stored in Clark Canyon Reservoir (about 12 mi southwest of the town of Barretts) from the Beaverhead River at a diversion dam near Barretts. This surface water primarily is used to irrigate hay and alfalfa on the terrace between the Beaverhead River and the East Bench Canal east of Dillon. Large-capacity wells completed in the basin-fill aquifer provide irrigation water for much of the Blacktail Deer Creek valley.

\section{Well-Numbering System}

Wells are identified in this report according to geographic position within the rectangular grid system used for the subdivision of public lands (fig. 2). The location number consists of as many as 14 digits and letters. An example of a location number used in this report is location number 07S08W19BADD01 for well 92-17. The first two digits and letter specify the town- 


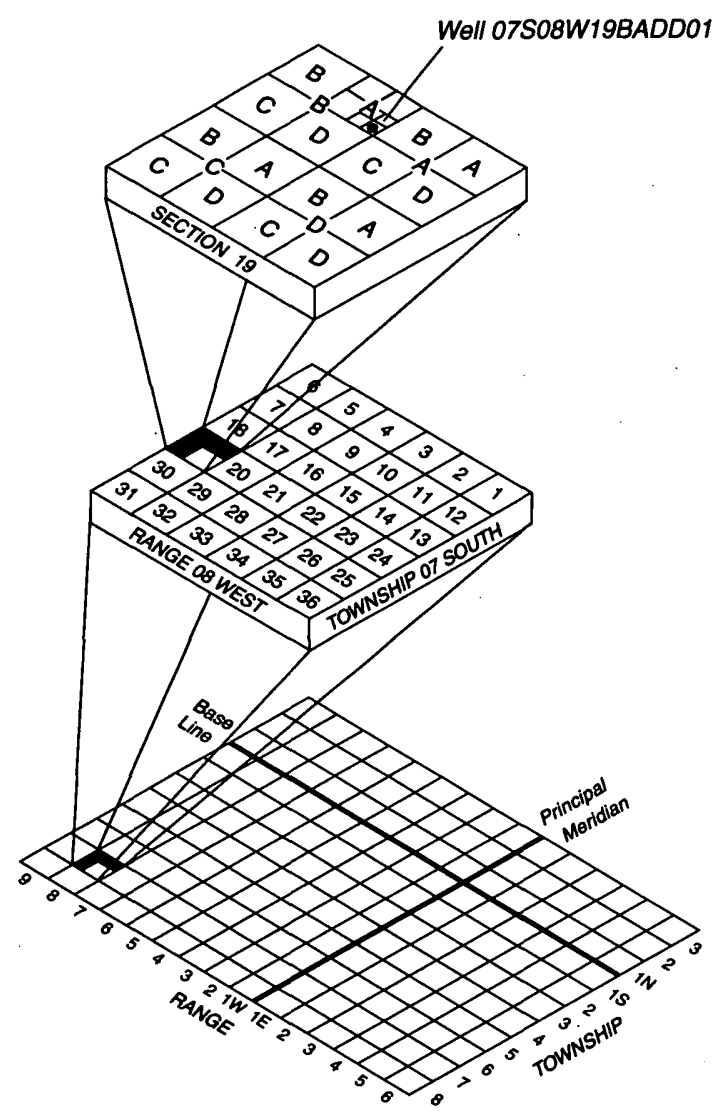

Figure 2. Well-numbering system.

ship and its position south (S) of the Montana Base Line. The next two digits and letter specify the range and its position west (W) of the Montana Principal Meridian. The next two digits represent the section number. The first letter following the section number denotes the quarter section (160-acre tract); the second letter denotes the quarter-quarter section (40-acre tract); the third letter, the quarter-quarter-quarter section (10-acre tract); and the fourth letter, the quarterquarter-quarter-quarter section (2.5 acre tract) in which the well is located. The subdivisions of the section are designated A, B, C, and D in a counterclockwise direction, beginning with the northeast quadrant. The last two digits form a sequence number indicating the order of inventory. For example, location number 07S08W19BADD01 is the first well inventoried in the southeast quarter of the southeast quarter of northeast quarter of the northwest quarter of sec. 19, T. 7 S., R. 8 W. All wells in the study area have ranges west of the
Montana Principal Meridian and townships south of the Montana Base Line.

\section{Acknowledgments}

The authors wish to thank property and well owners in the study area for their cooperation, the East Bench Irrigation District for use of their equipment and facilities, and the City of Dillon and staff of the Bureau of Reclamation for their cooperation.

\section{HYDROGEOLOGIC ANALYSIS}

The basin-fill aquifer in the lower Blacktail Deer Creek, lower Beaverhead River, and lower Rattlesnake Creek valleys consists of unconsolidated alluvial deposits of Quaternary age and semi-consolidated and consolidated valley-fill deposits of Tertiary age. According to available well logs and aquifer-test data, 
the aquifer is at least $485 \mathrm{ft}$ thick near the center of the study area, and is about $160 \mathrm{ft}$ thick near the mouth of Sheep Creek Canyon, located in the south-central part of the study area. The surficial geology of the area (Ruppel and others, 1993) is shown in figure 3. In general, the aquifer consists of coarse sand and gravel with discontinuous layers of silt and clay. Alluvial-fan deposits (Qf) overlie parts of the alluvium (Qa) in the study area (fig. 3). The aquifer in the Blacktail Deer Creek valley is bounded laterally by bedrock consisting of various types of deposits of Tertiary age (Tbz, Tvu), carbonates of Paleozoic age (Pzls), and a gneiss of Archean age (Ag). Deposits bordering the aquifer along most of the northeastern part of the study area consist of the lower part of the Bozeman Group and related valley-fill deposits of Tertiary age (Tbz). Bedrock bordering the aquifer along the northwestern and western sides of the valley consists mostly of andesitic volcanic rocks of Tertiary age (Tvu). Bedrock bordering the aquifer along most of the southwestern side of the valley consists primarily of Paleozoic carbonates (Pzls). Bedrock bordering the aquifer along most of the southeastern side of the valley is primarily a silicate gneiss of Archean age (Ag). The base of the aquifer typically is bounded by the lower part of the Bozeman Group and related valley-fill deposits (Tbz) or by volcanic rocks (Tvu), Paleozoic carbonates (Pzls), and Archean gneiss (Ag). The lower part of the Tertiary deposits (Tbz), described in well logs, consist of a low permeability brownish silt or siltstone. For a more detailed description of the geology of the area, the reader is referred to Botz (1967), Fields and Petkewich (1967), Hanneman and Wideman (1991), and Klepper (1950).

The basin-fill aquifer is unconfined throughout the valley, except where it is locally confined or semiconfined by fine-grained deposits. The aquifer is recharged by infiltration of precipitation and snowmelt, irrigation recharge, and ground-water inflow from adjacent or underlying bedrock. Water discharges from the aquifer by evapotranspiration; withdrawals from wells for domestic, irrigation, and stock use; and seepage to the Beaverhead River and adjacent sloughs. Some water flows out of the study area within the aquifer.

The Beaverhead River is the main surface-water feature in the valley and flows generally northeast, from Barretts toward Dillon (fig. 1). The river is fed by tributaries (Blacktail Deer Creek and Rattlesnake
Creek) and flow from sloughs near the river. Data collected from synoptic streamflow measurements conducted by the DNRC indicate that the Beaverhead River loses water between Barretts and the upper end of the sloughs and gains water between the sloughs and Dillon (William Uthman, Montana Department of Natural Resources and Conservation, written commun., 1995). The other major surface-water feature in the valley is the East Bench Canal, an irrigation canal located in the lower part of the Blacktail Deer Creek valley.

Locations of wells, springs, and surface-water sites sampled during the study are shown in figure 4. Information concerning the construction records of the wells and the water-levels measured September 16, 1993, are listed in table 1. Information on the springs and surface-water sites is listed in table 2. Thirty-eight monitoring wells, including 10 nested wells consisting of a shallow and deep well in each nest, were installed from 1991-93 by the DNRC as part of their cooperative study with the BOR in the Beaverhead River valley. These wells are designated in table 1 by a site number consisting of a 91- or 92- prefix. Most of these wells were constructed with open intervals (perforated or screened) of $10 \mathrm{ft}$ or less. Other wells inventoried during the study and listed in table 1 begin with the prefix W. Most of these wells were installed prior to 1991 and, if known, have open intervals of various depths. Primary use of water from these wells includes irrigation, public supply, domestic, stock, and industrial use. Most of the wells listed in this category are domestic or irrigation wells.

Water levels have been measured on a nearmonthly basis since 1991 by the DNRC at as many as 79 wells, including their observation wells and selected domestic and irrigation wells, in the study area (William Uthman, written commun., 1995). Thirty-one of these wells were constructed between August 1992 and June 1993, so water-level data at these wells are only available since these dates. Hydrographs constructed from water levels measured in three wells (91-2, 91-4, and 92-4) located near Blacktail Deer Creek and from stream discharge measurements collected at streamflow-gaging station 06017500 (site SW5) located on Blacktail Deer Creek near Dillon are shown in figure 5. The hydrographs show the interaction of Blacktail Deer Creek and the basin-fill aquifer near the stream (William Uthman, written commun., 1997). Variations in water levels in the wells are greatest near the stream (well 91-2) and decrease away from the stream (well 




Base from U.S. Geological Survey digital data, 1:100,000, 1983 Universal Transverse Mercator projection, Zone 12

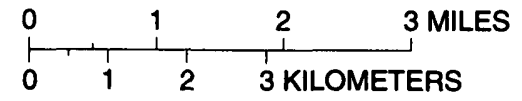

Figure 3. Generalized geology near Dillon, Montana (modified from Ruppel and others, 1993). 
ALLUVIUM (QUATERNARY)--Silt, sand, and gravel in channels and beneath flood plains of major rivers and streams and in related alluvial fans. May be partly of Pleistocene age

LANDSLIDE DEPOSITS (QUATERNARY)--Angular fragments of bedrock mixed with soil or heterogenous boulders and finer grained material derived from glacial deposits on steep valley walls; characterized by irregular hummocky topography; boggy in places. Many landslides are marked by torn sod, tilted trees, and steep unvegetated slopes that indicate continuing movement

ALLUVIAL-FAN DEPOSITS (QUATERNARY)--Poorly sorted silty sand and gravel deposited in broad alluvial fans along valley margins. Includes gravel veneer on pediments

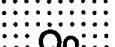

GLACIAL OUTWASH (QUATERNARY)--Poorly sorted bouldery gravel and sand deposited by glacial meltwater

BOZEMAN GROUP AND RELATED VALLEY-FILL DEPOSITS, UNDIVIDED

(PLIOCENE TO EOCENE)--Moderately indurated to well-indurated tuffaceous sandstone and siltstone containing subordinate interbeds of limestone and marl and lenses of pebble and cobble conglomerate composed of locally derived rock fragments. Commonly veneered with residual gravel or a thin layer of eolian sand. Includes Tertiary landslide deposits derived from flanking mountains

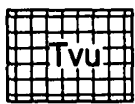

VOLCANIC ROCKS (TERTIARY)--Basaltic andesite, andesite, dacite, and rhyodacite. Fine-grained, locally porphyritic volcanic and associated intrusive rocks. Phenocrysts include sodic plagioclase, sanidine, quartz, and biotite. Individual flows as much as $50 \mathrm{~m}$ in thickness

BEAVERHEAD GROUP (TERTIARY? AND UPPER CRETACEOUS)--Moderately indurated massive boulder, cobble, and pebble conglomerate having a quartz-sand matrix and cemented with calcite, and some interbedded sandstone and freshwater limestone; in most places these rocks consist of rounded to subangular fragments of Proterozoic quartzite and Paleozoic carbonate rocks

CLASTIC AND CARBONATE ROCKS, UNDIFFERENTIATED (MESOZOIC)--Includes the Kootenai Formation (Lower Cretaceous) and Thaynes Limestone, Woodside Formation, and Dinwoody Formation (Lower Triassic)--Primarily marine shale with interbedded nonmarine sandstone, siltstone, mudstone, and marine limestone

CARBONATE AND CLASTIC ROCKS, UNDIFFERENTIATED (PALEOZOIC)--Includes the Phosphoria Formation and related rocks (Permian), Quadrant Formation (Pennsylvanian and Upper Mississippian), Snowcrest Range Group (Lower Pennsylvanian and Upper Mississippian), Madison Group (Upper and Lower Mississippian), Three Forks Shale and Jefferson Formation (Mississippian? and Upper and Middle Devonian), and Cambrian rocks (Upper and Middle Cambrian)--Primarily massive and thick-to thin-bedded limestone with dolomite, interbedded phosphatic sandstone, quartzite, siltstone, mudstone, and shale

$\because \because \cdots$ $\therefore$ Ag

GNEISSIC ROCKS (ARCHEAN)--Well-foliated biotite-hornblende-garnet gneiss, migmatite, augen gneiss, and aluminous schist

\section{CONTACT}

NORMAL FAULT--Dashed where approximately located

THRUST FUALT--Saw teeth on upper plate 


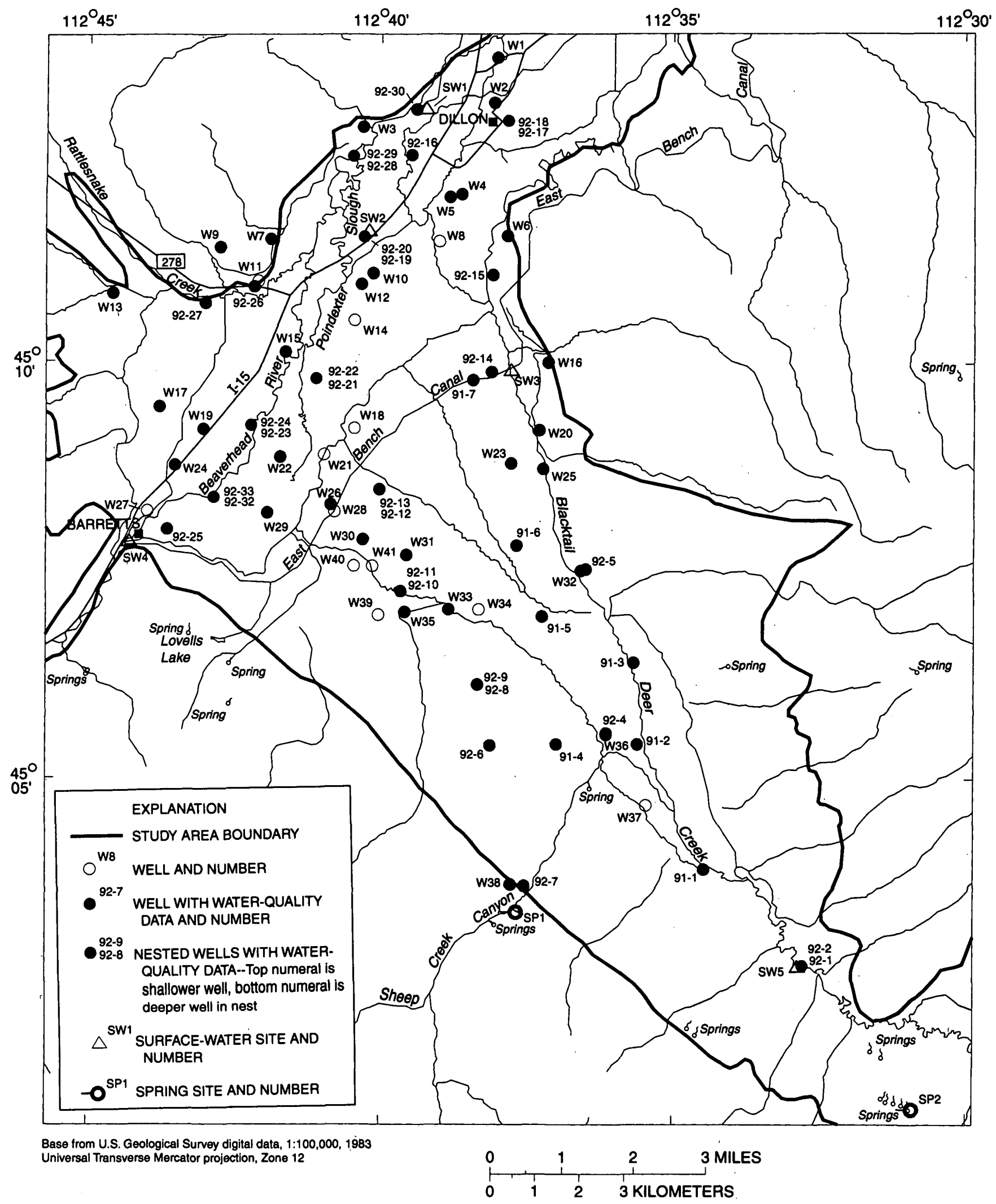

Figure 4. Locations of wells, springs, and surface-water sites near Dillon, Montana. 


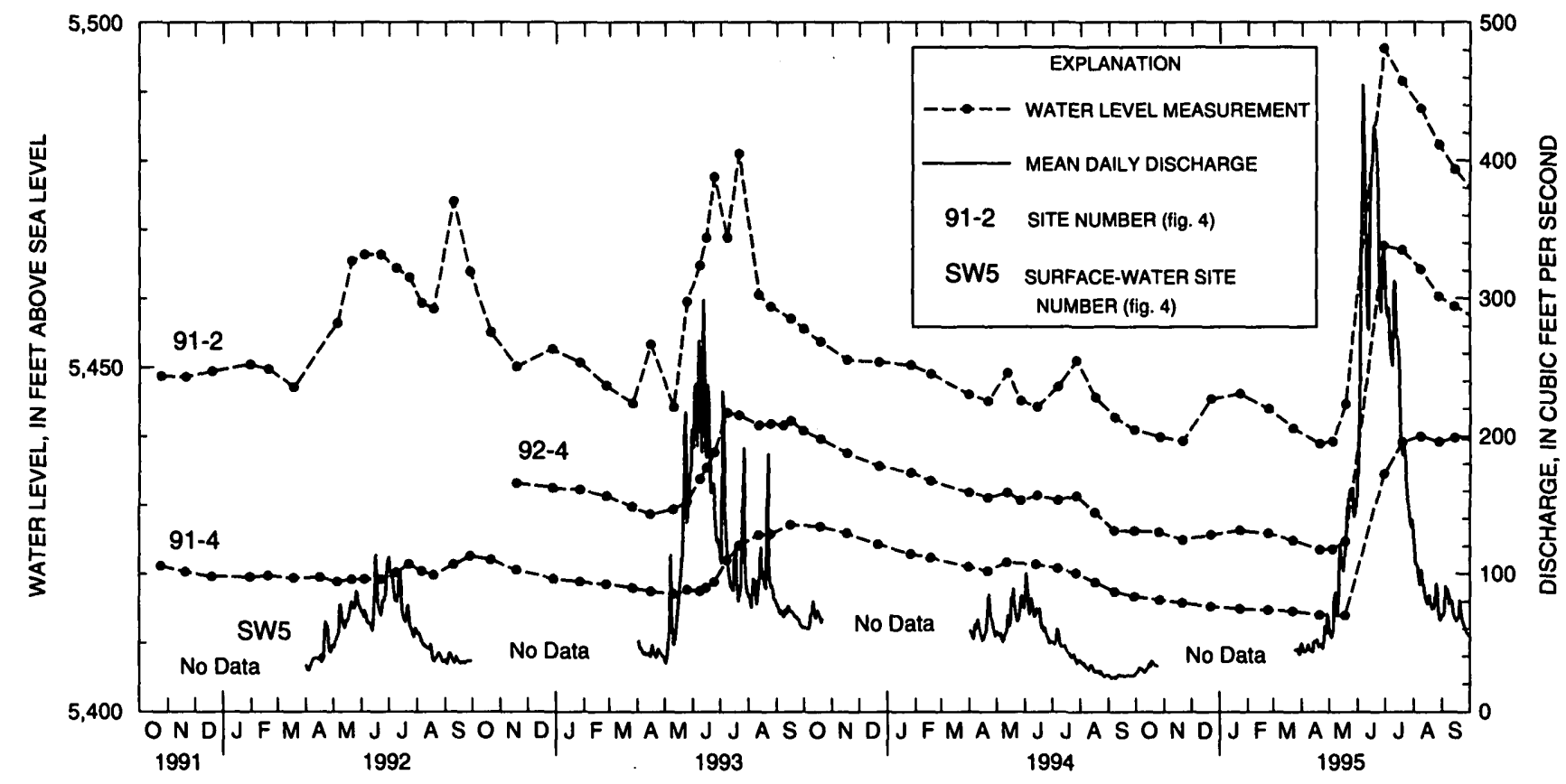

Figure 5. Water level measurements in wells near Blacktail Deer Creek, and mean daily discharge at Blacktail Deer Creek near Dillon, Montana (site SW5), for 1991-95.

91-4). Substantial recharge to the ground-water system is apparent during the wet summers of 1993 and 1995.

A potentiometric-surface map of the basin-fill aquifer for September 16, 1993, is shown in figure 6. The water levels used to construct the map are representative of conditions that existed during the waterquality and CFC sampling period from August 20 through September 15, 1993. Ground-water flow in the Blacktail Deer Creek valley generally is from southeast to northwest, toward the Beaverhead River. The aquifer is recharged by seepage from Blacktail Deer Creek, from the limestone bedrock located along the southwestern edge of the valley near Sheep Creek Canyon, and from infiltration of precipitation, snowmelt, and irrigation water. Gradients are steepest in the upper and middle parts of the study area and are more gentle in the lower part of the valley and near the Beaverhead River.

Line of section K-K' (fig. 6) is used to show the generalized flow path from a recharge area near the mouth of Sheep Creek Canyon to a discharge area at a slough near the Beaverhead River. The flow system along this flow path is described in greater detail later in the report using ground-water tracer ages and a cross-sectional flow model.

\section{GEOPHYSICAL ANALYSIS}

Available well-log data were assembled by the DNRC and used to develop a preliminary hydrogeologic framework of the study area. Areas with sparse data were identified for further investigation using geophysical seismic-refraction surveys. The seismicrefraction surveys were conducted in 1994 to help define the geometry of the basin-fill aquifer in the lower Beaverhead River, Blacktail Deer Creek, and lower Rattlesnake Creek valleys. The surveys also were used to develop profiles from 10 designated lines of section (fig. 7) to further define the hydrogeology and flow system in the study area. The profiles developed were used to help define the depth to the Quaternary-Tertiary contact, other lithologic contacts, and depths to the water table and bedrock, when possible.

\section{Methods}

The seismic-refraction technique measures the time it takes a compressional sound wave, generated by a sound source at or near land surface, to travel down through layers of earth materials, along acoustical interfaces that generally correspond to the ground- 


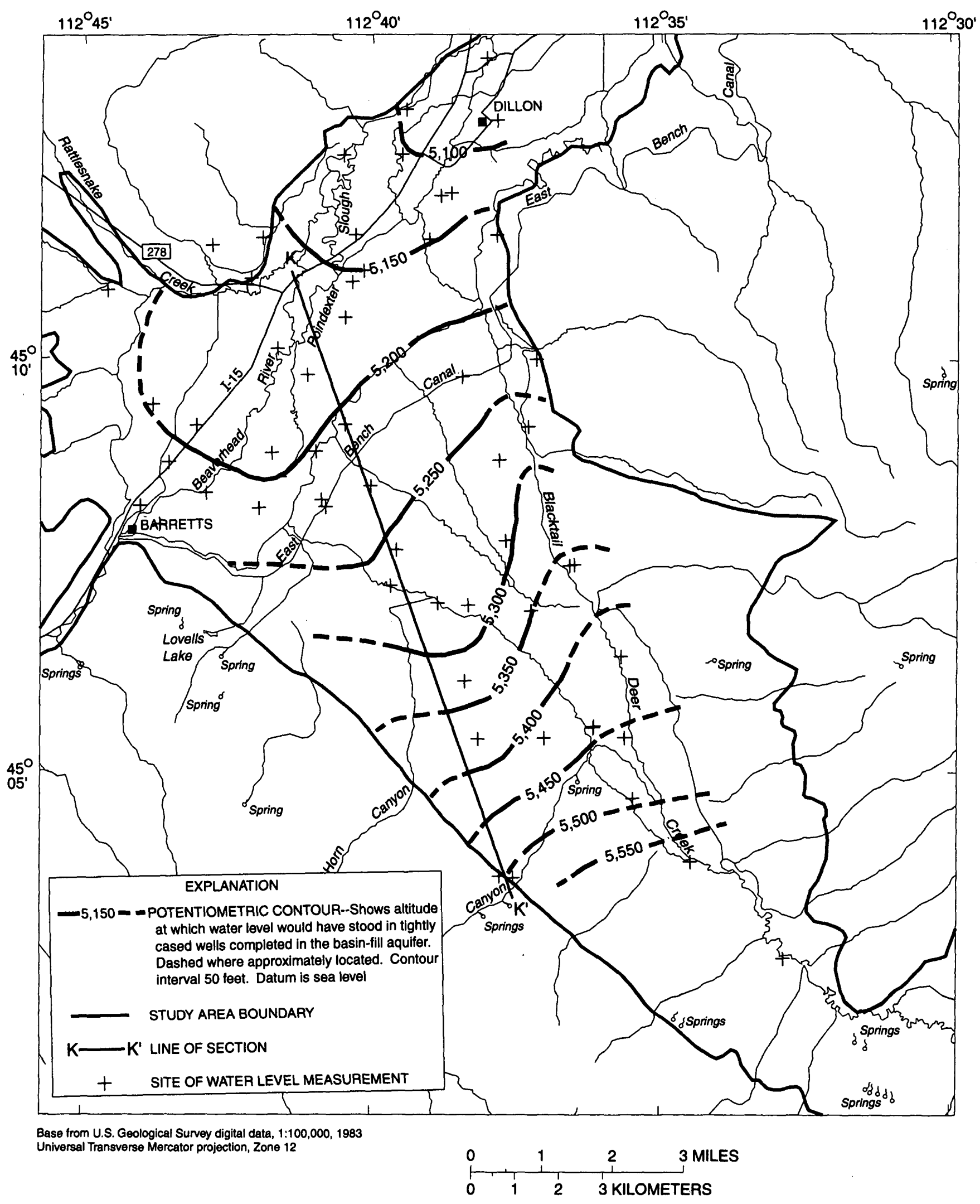

Figure 6. Potentiometric surface of the basin-fill aquifer near Dillon, Montana, September 16, 1993. 


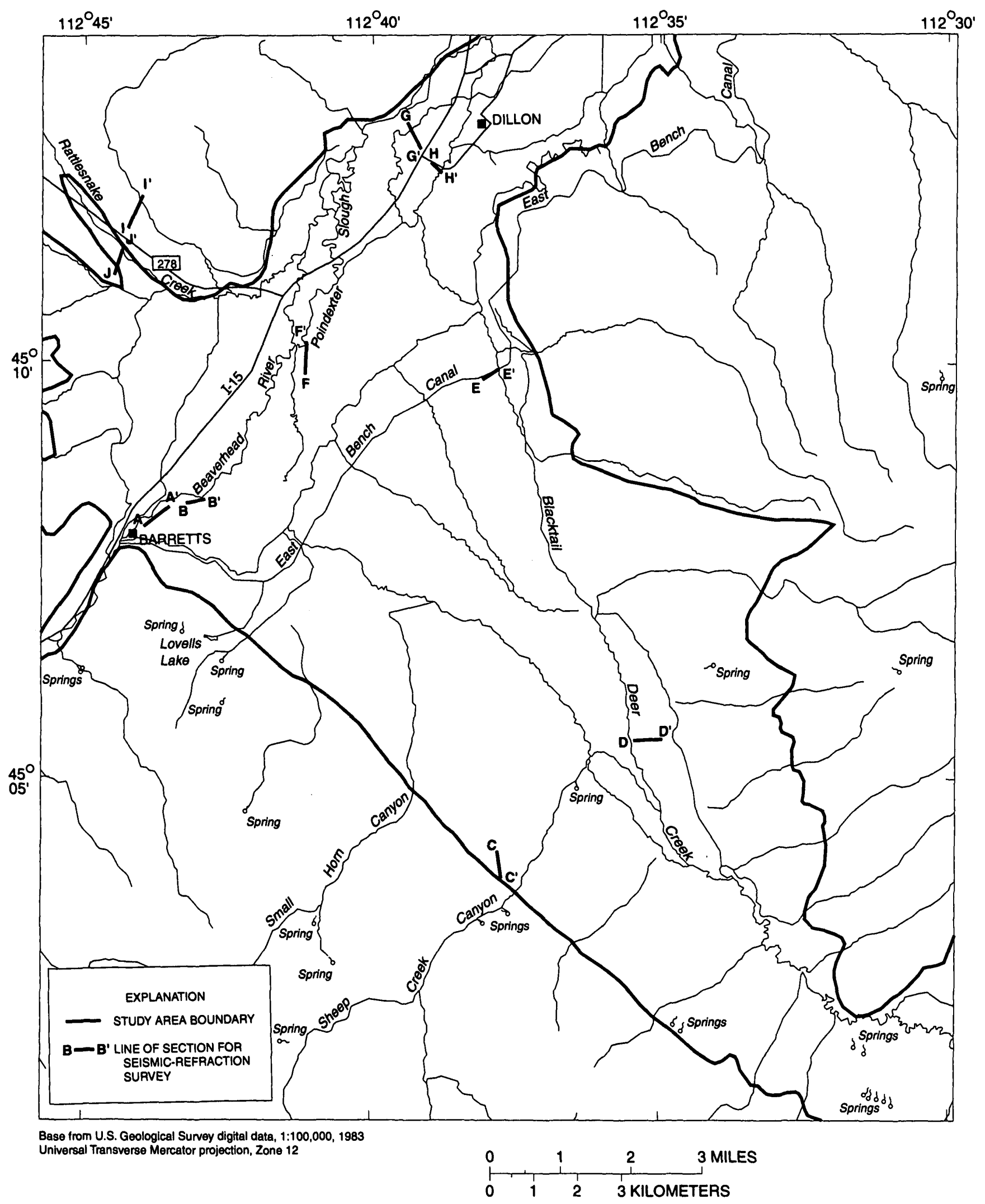

Figure 7. Location of seismic-refraction profiles near Dillon, Montana. 
water surface or lithologic contacts, and back up to ground-motion detectors (geophones) placed on the land surface. By measuring the travel-time of the sound wave and applying Huygen's principle and Snell's law (Telford, 1976, p. 218-261, 363-370) that govern the propagation of sound through different materials, the subsurface hydrogeology can be inferred. The field data consist of measured distances between seismic sound sources and geophones, and seismic travel times. From this time-distance information, variations in velocity of sound waves and depths of travel to individual layers can be calculated and modeled (Haeni, 1988). Average compressional seismic velocities for various earth materials are listed in table 3.

The seismic-refraction technique has several applications, one of which includes determining the depth of a shallow water table. In unconsolidated and semi-consolidated deposits, the compressional wave velocity increases abruptly at the water table. Seismically determined water-table altitudes typically are within a few feet of that determined by water-level measurements in a well in areas where depth to the water table is less than $100 \mathrm{ft}$ (Haeni, 1988, table 3). This technique typically is useful for locating depths to the water table, for finding velocity differences in various geologic materials, and for locating contacts between geologic units at relatively shallow depths.

\section{Limitations of Method}

Interpretation of seismic-refraction data are limited in cases where the layer has insufficient thickness to return first-arrival energy or where there is insufficient seismic-velocity contrast between layers of interest. In addition, the method is not applicable if the velocity of compressional sound waves does not increase with depth in each successive layer. Another limit of the seismic-refraction technique can be the inability to locate lithologic contacts at great depths due to limitations placed on layout of the geophone array, placement of explosives, and the requirement of large explosive charges to propagate sound waves to great depths. The reader is referred to Haeni (1988) for more information concerning the seismic-refraction methods used in this study.

\section{Field Procedure}

Seismic-refraction geophone spreads used in this investigation consisted of geophones placed on land surface as a linear array. Seven of the surveys conducted (A-A', C-C', D-D', F-F', G-G', I-I', and J-J') had an array length of $2,300 \mathrm{ft}$, and 3 surveys (B-B', E-E', and H-H') had an array length of $1,100 \mathrm{ft}$. (fig. 8). Spacing between geophones was $100 \mathrm{ft}$ in all 10 surveys. The geometry of the geophone spacing for each refraction spread was designed so that the survey's depth of exploration focused on the shallow part of the subsurface environment.

The seismic data were recorded on a seismograph. Seismic waves were generated by explosive charges. The explosive charges were placed below ground surface and in some cases below the water table. The explosive charges provide the energy needed to profile long distances and greater depths.

Table 3. Average compressional velocities of sound for various earth materials in the lower Blacktail Deer Creek, lower Beaverhead River, and lower Rattlesnake Creek valley near Dillon, Montana

[Abbreviations: Qa, Quaternary alluvium; Qf, Quaternary alluvial-fan deposits; Qo, Quaternary glacial outwash; Tbz, Tertiary Bozeman Group; Tvu, Tertiary volcanic rocks; Pzls, Paleozoic carbonate and clastic rocks; Ag, Archean gneissic rocks]

\begin{tabular}{|c|c|}
\hline Material & $\begin{array}{c}\text { Average compressional } \\
\text { velocity } \\
\text { (feet per second) }\end{array}$ \\
\hline Alluvial deposits (Qa, Qf, Qo,) & 1,500 \\
\hline Alluvium (Qa) & 4,950 \\
\hline Bozeman Group (Tbz) & 7,400 \\
\hline Volcanic rocks (Tvu) & 12,000 \\
\hline Paleozoic carbonates (Pzls) & $10,000-12,000$ \\
\hline Archean gneiss ( $\mathrm{Ag})$ & 14,000 \\
\hline
\end{tabular}


SOUTHWEST

NORTHEAST

A

GEOPHONE STATION

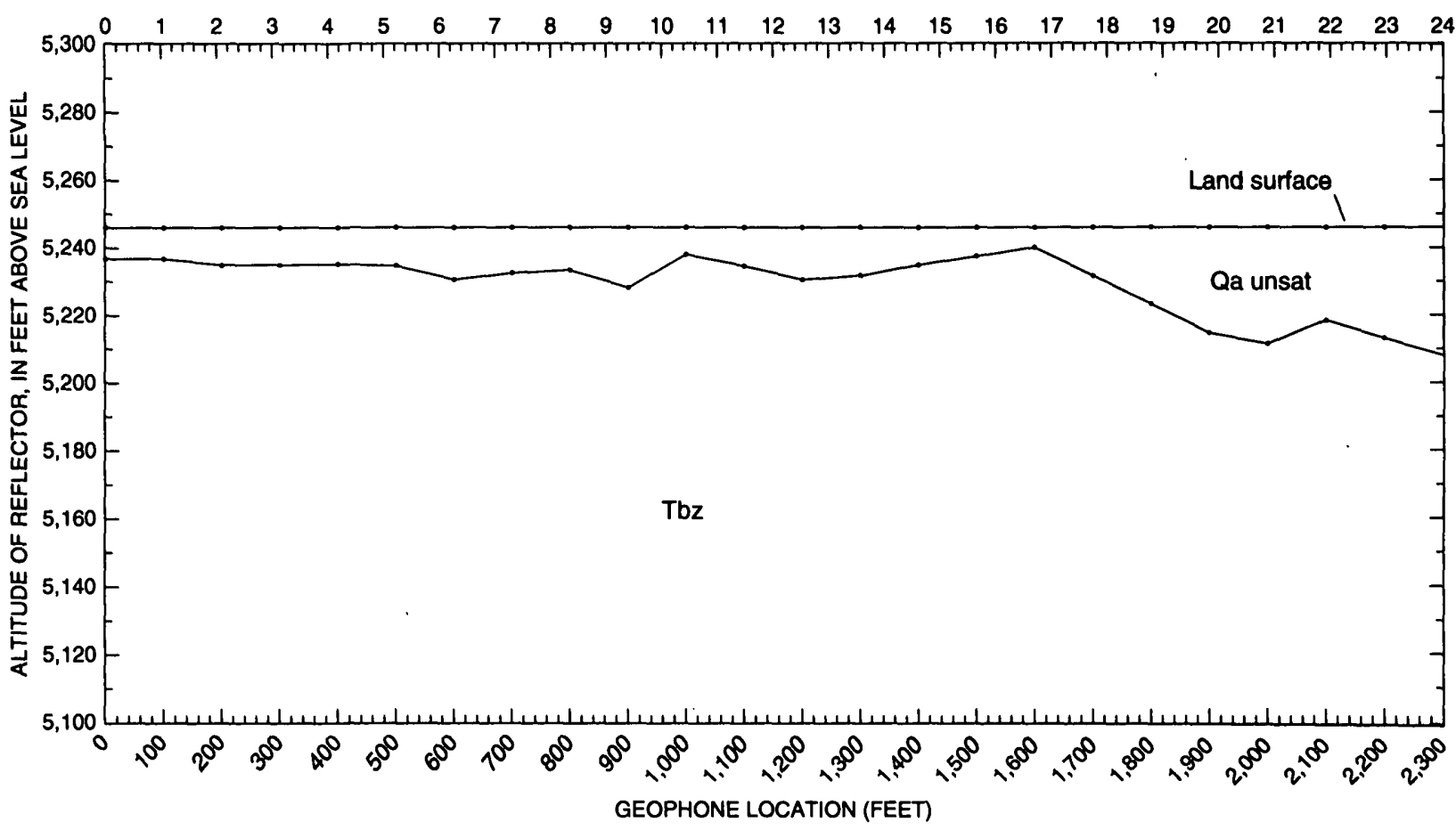

EXPLANATION

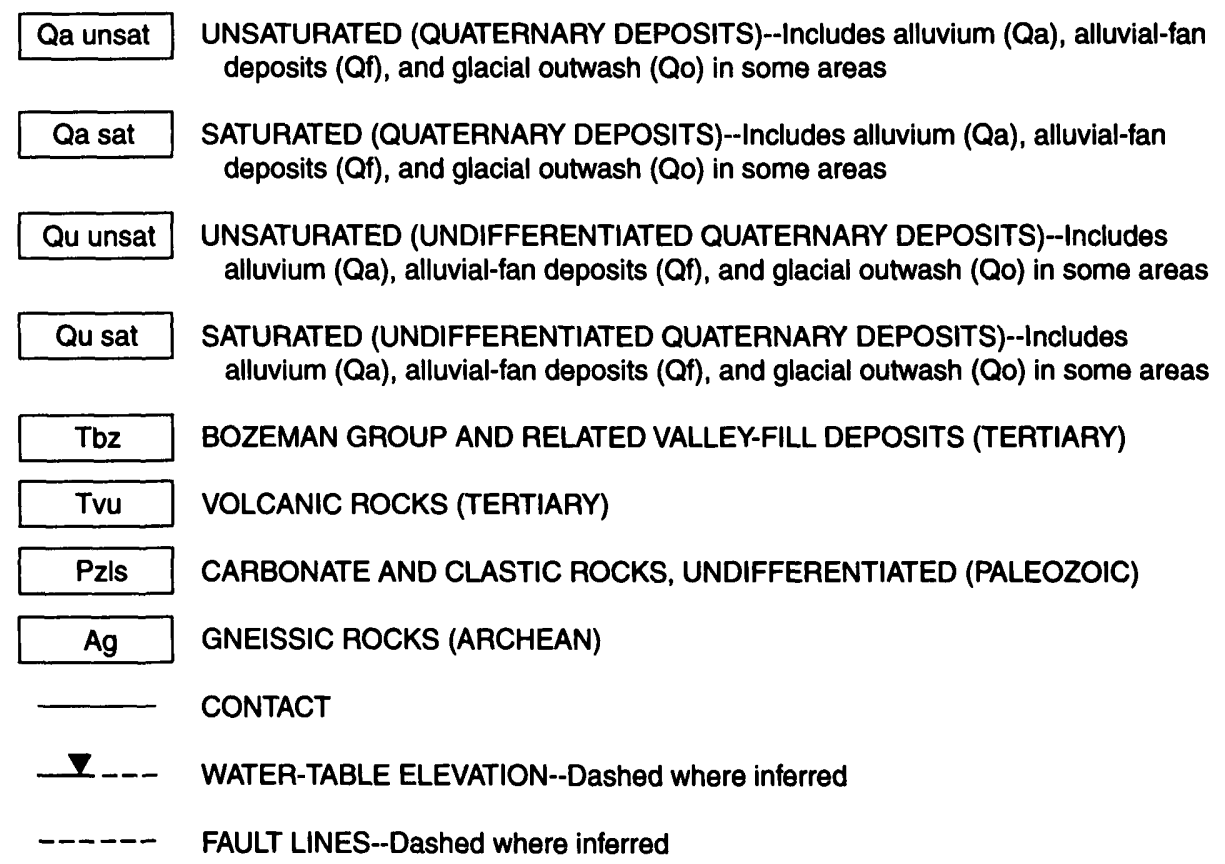

Figure 8. Geophysical profiles determined from seismic-refraction data. Lines of section are shown in figure 7. 

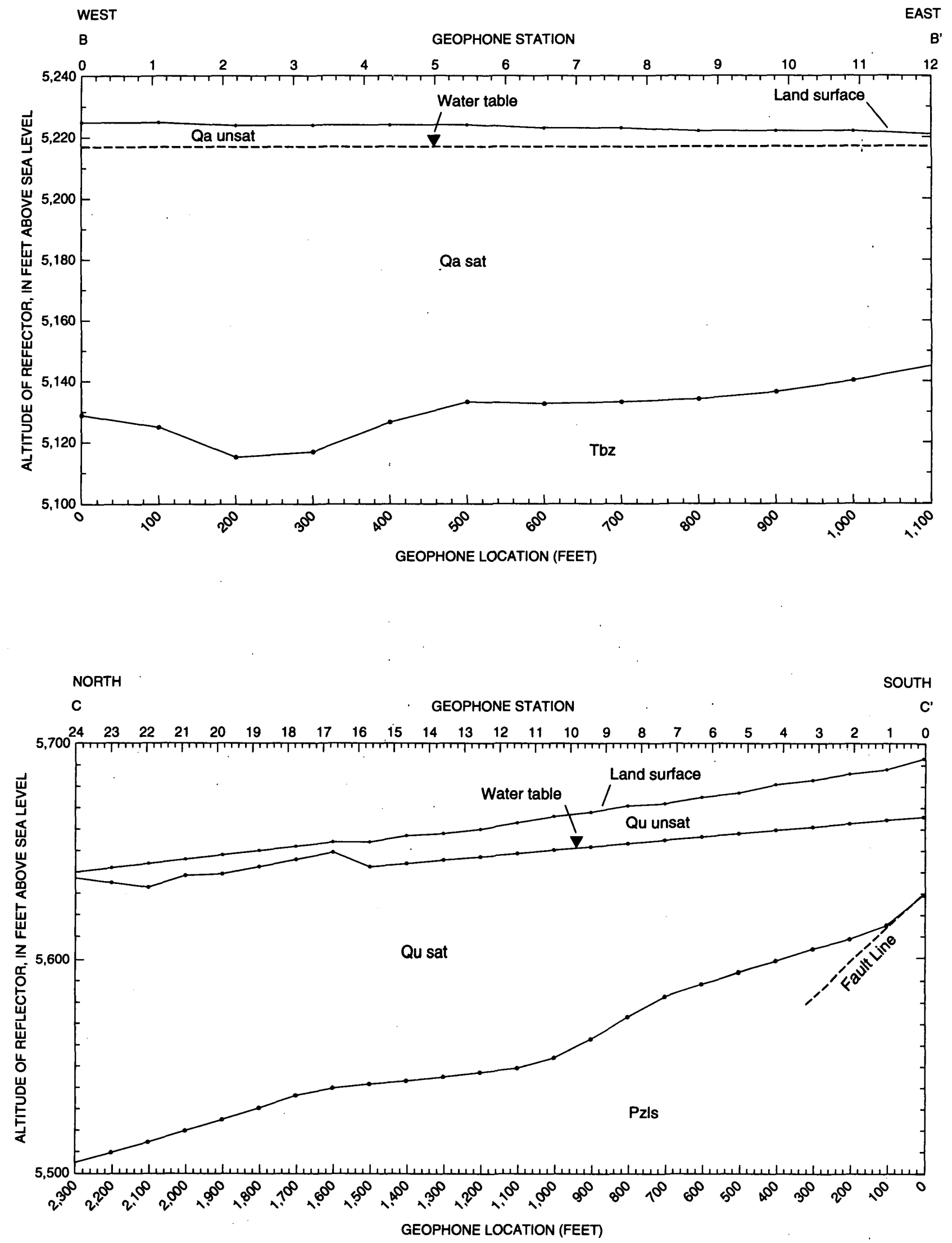

Figure 8. Geophysical profiles determined from seismic-refraction data. Lines of section are shown in figure 7 (Continued). 


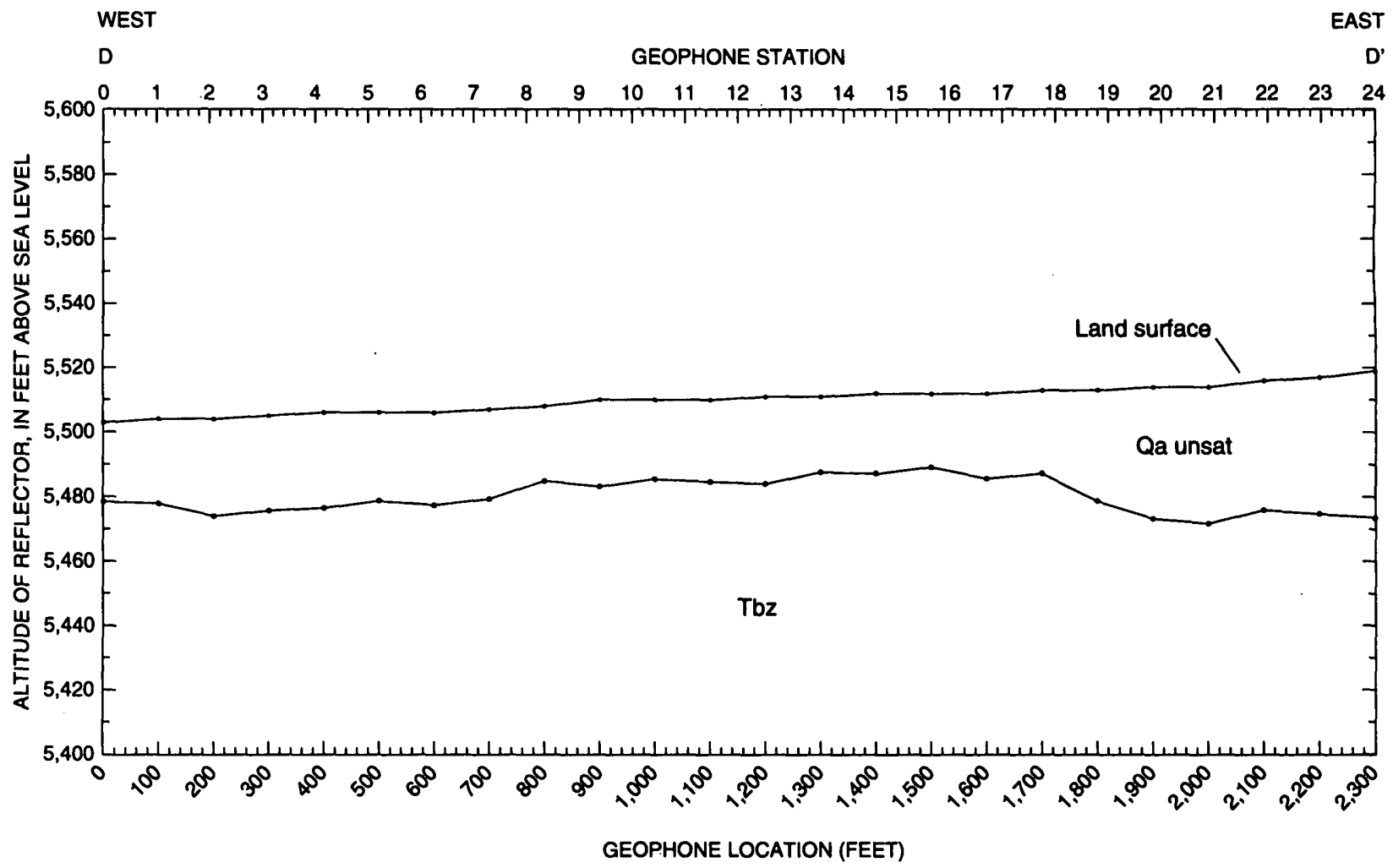

SOUTHWEST

NORTHEAST

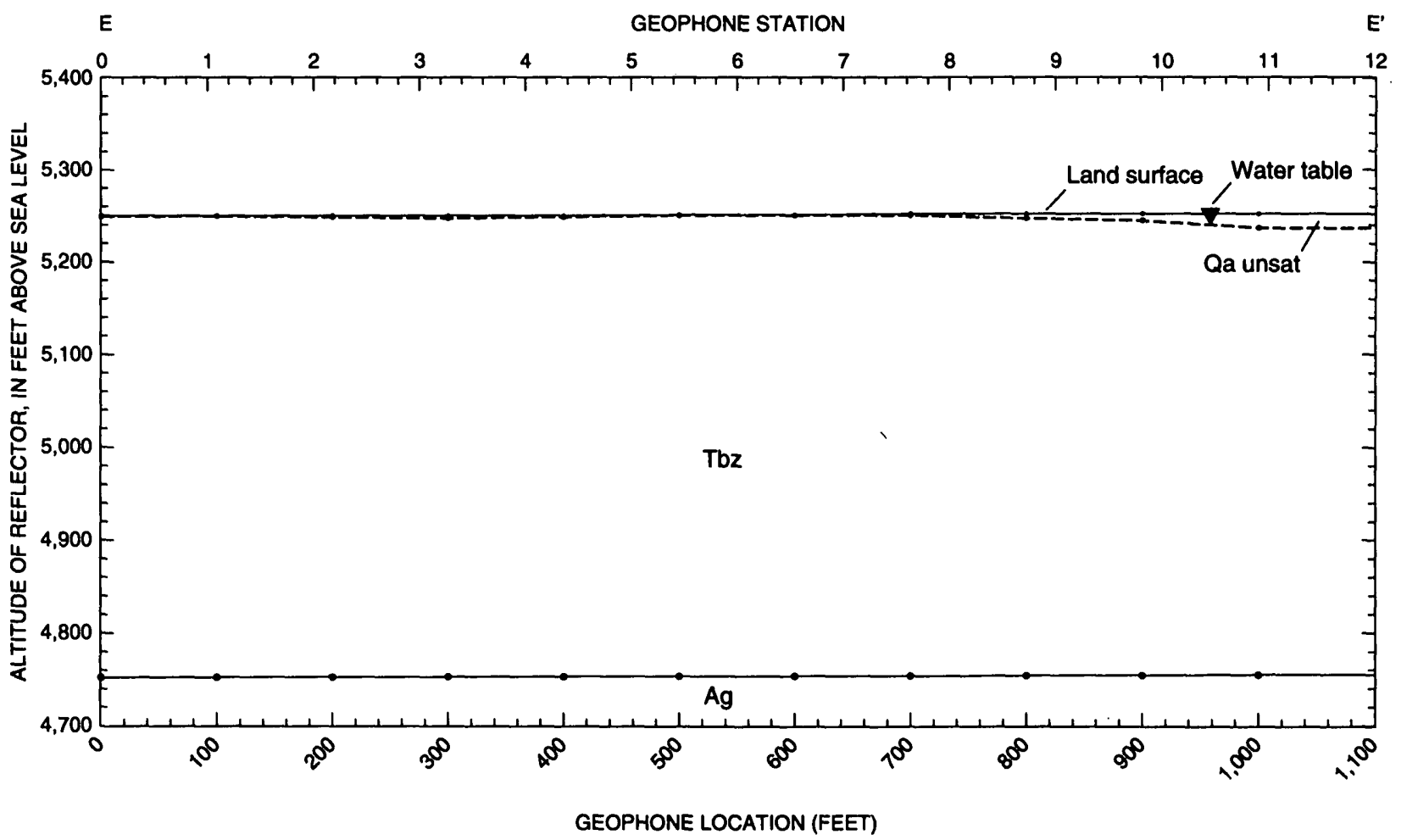

Figure 8. Geophysical profiles determined from seismic-refraction data. Lines of section are shown in figure 7 (Continued). 
SOUTH

NORTH GEOPHONE STATION

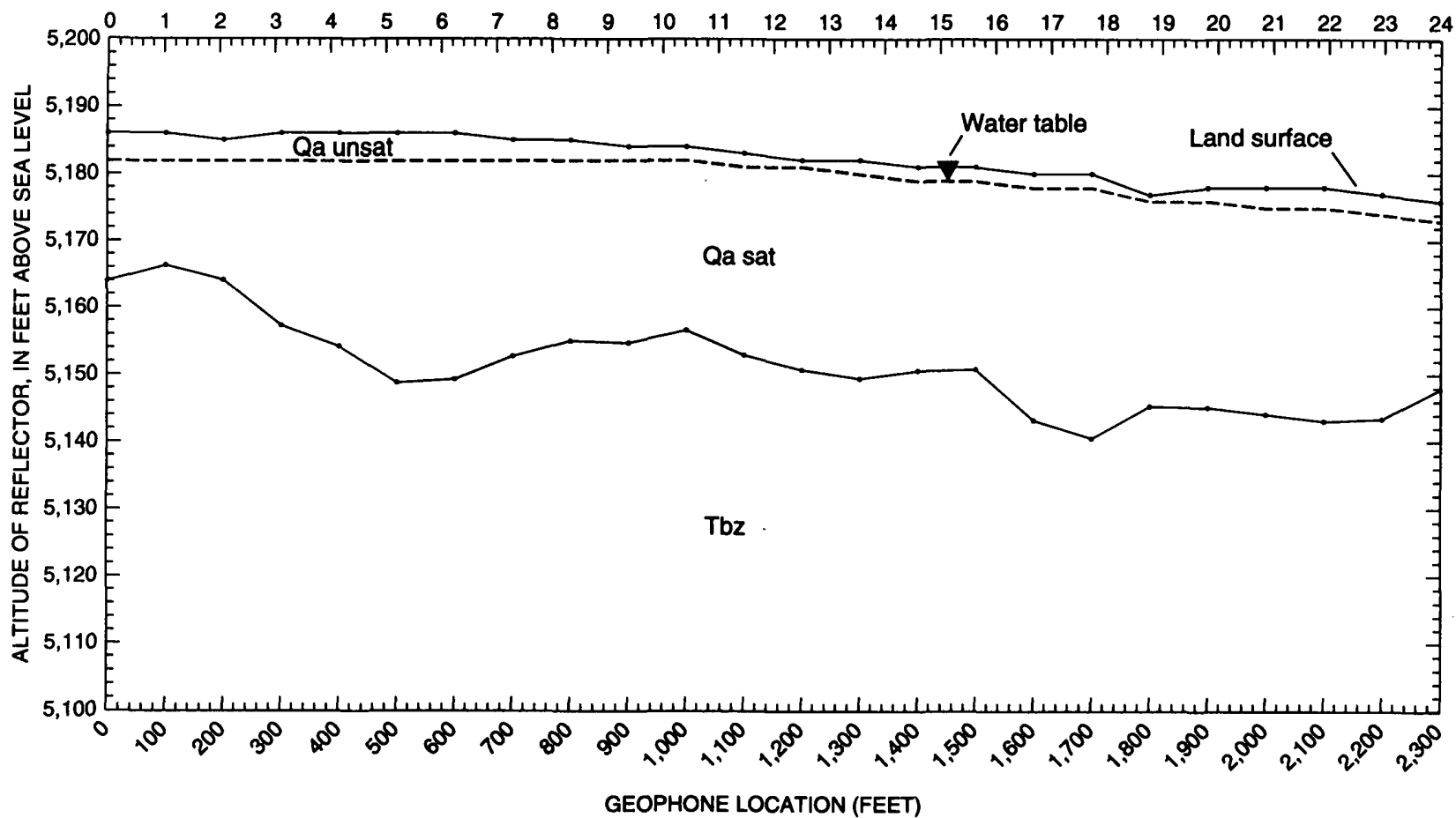

NORTHWEST

SOUTHEAST

G

GEOPHONE STATION

G'

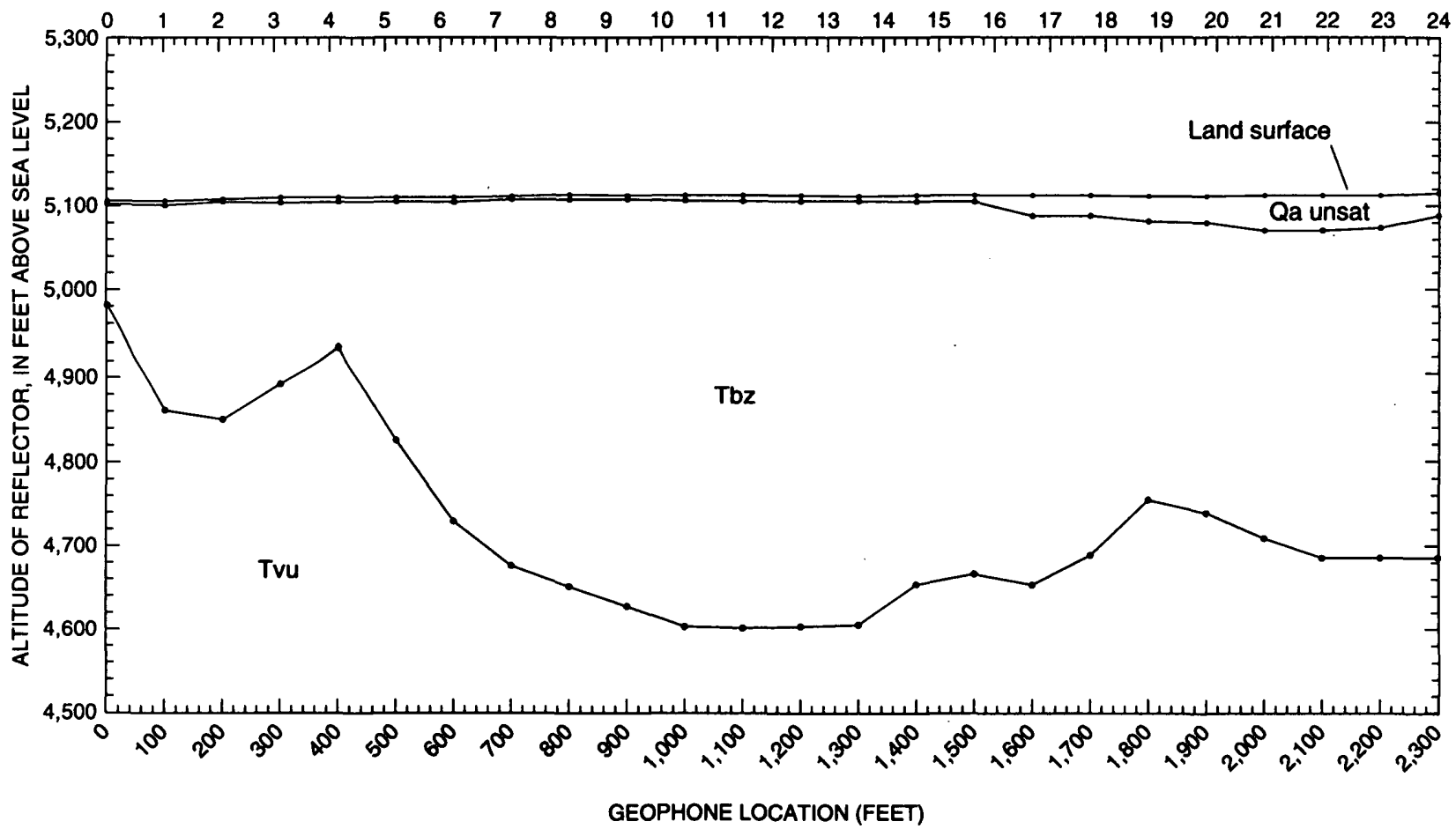

Figure 8. Geophysical profiles determined from seismic-refraction data. Lines of section are shown in figure 7 (Continued). 


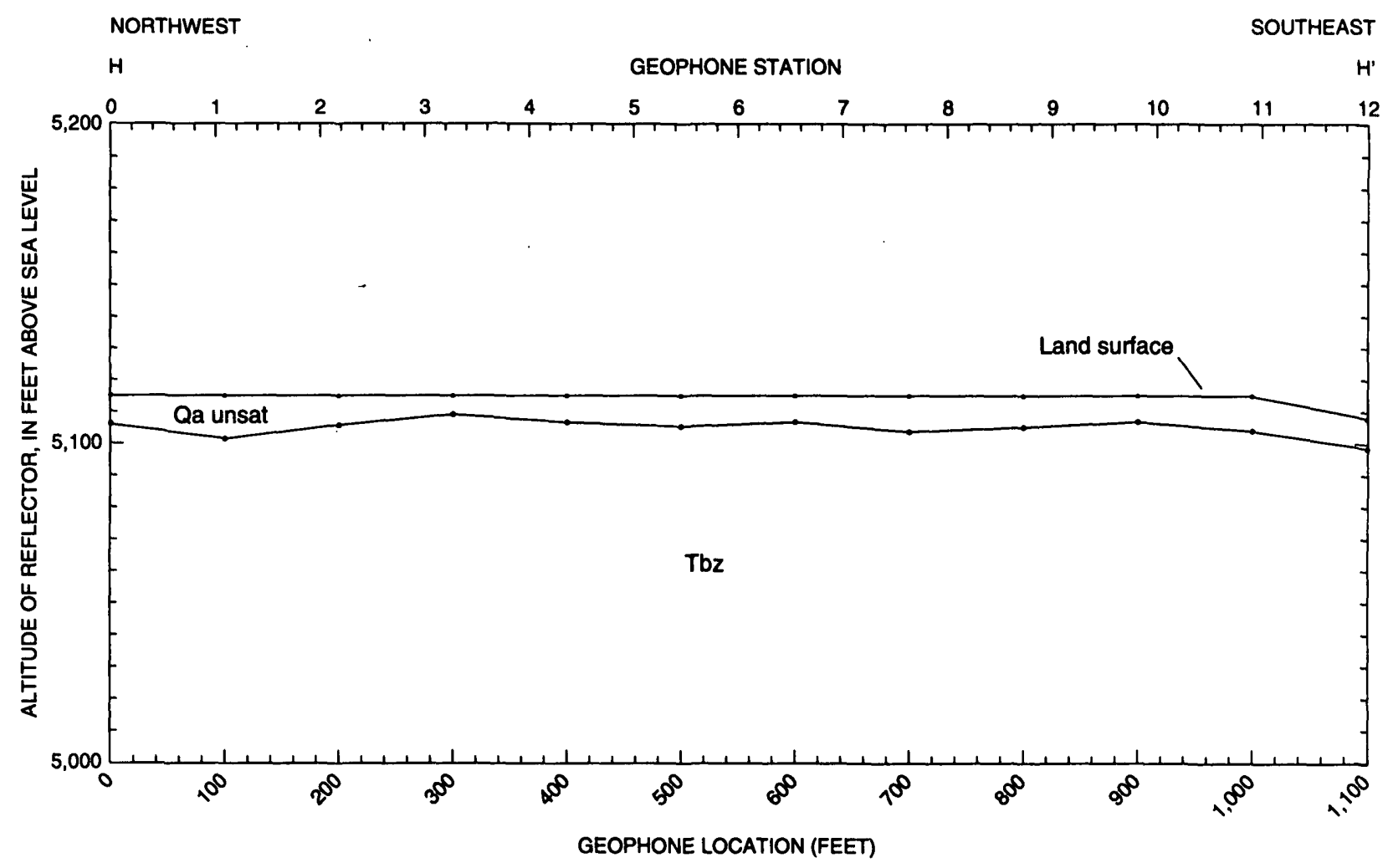

SOUTHWEST

NORTHEAST

GEOPHONE STATION

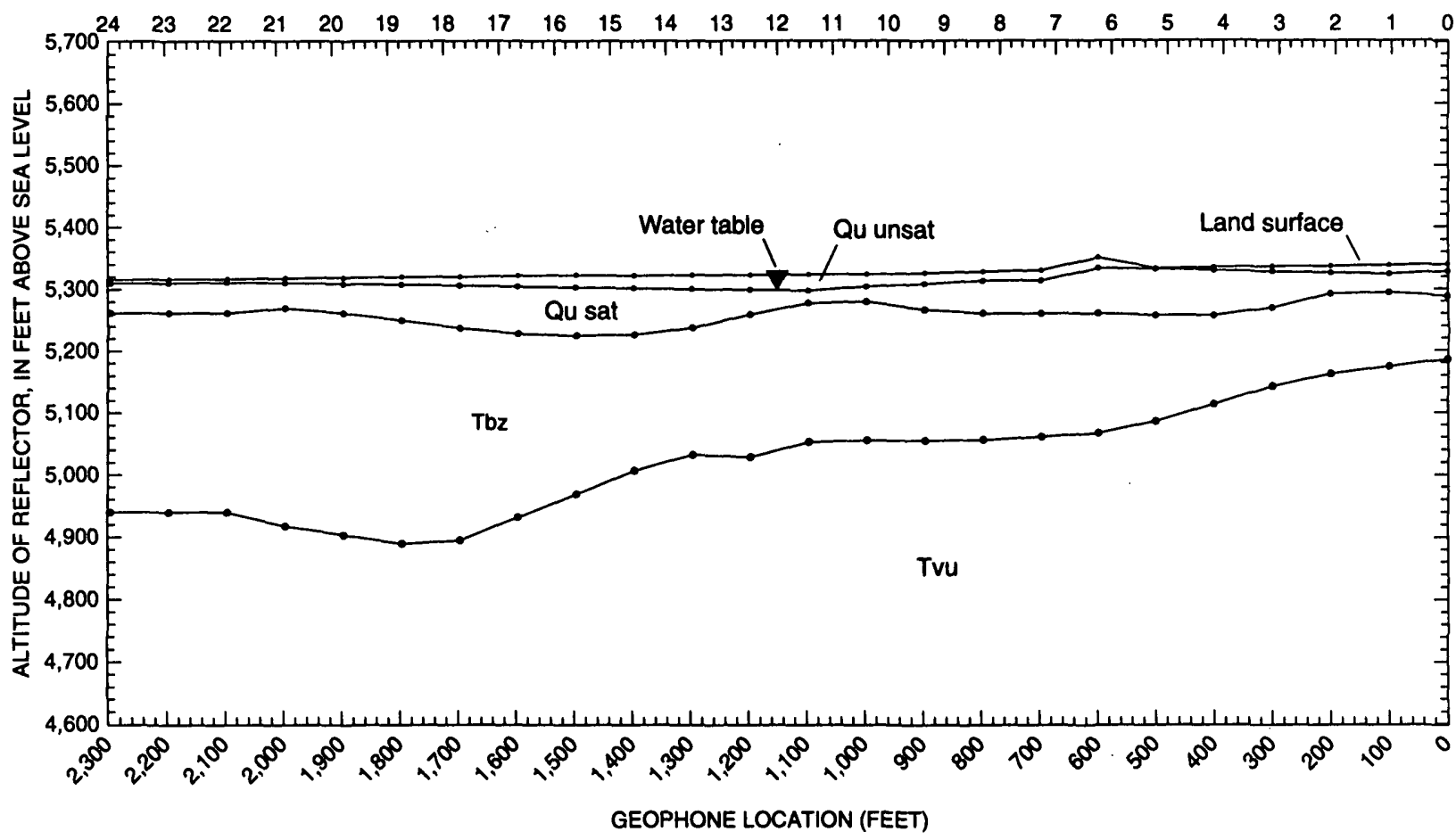

Figure 8. Geophysical profiles determined from seismic-refraction data. Lines of section are shown in figure 7 (Continued). 


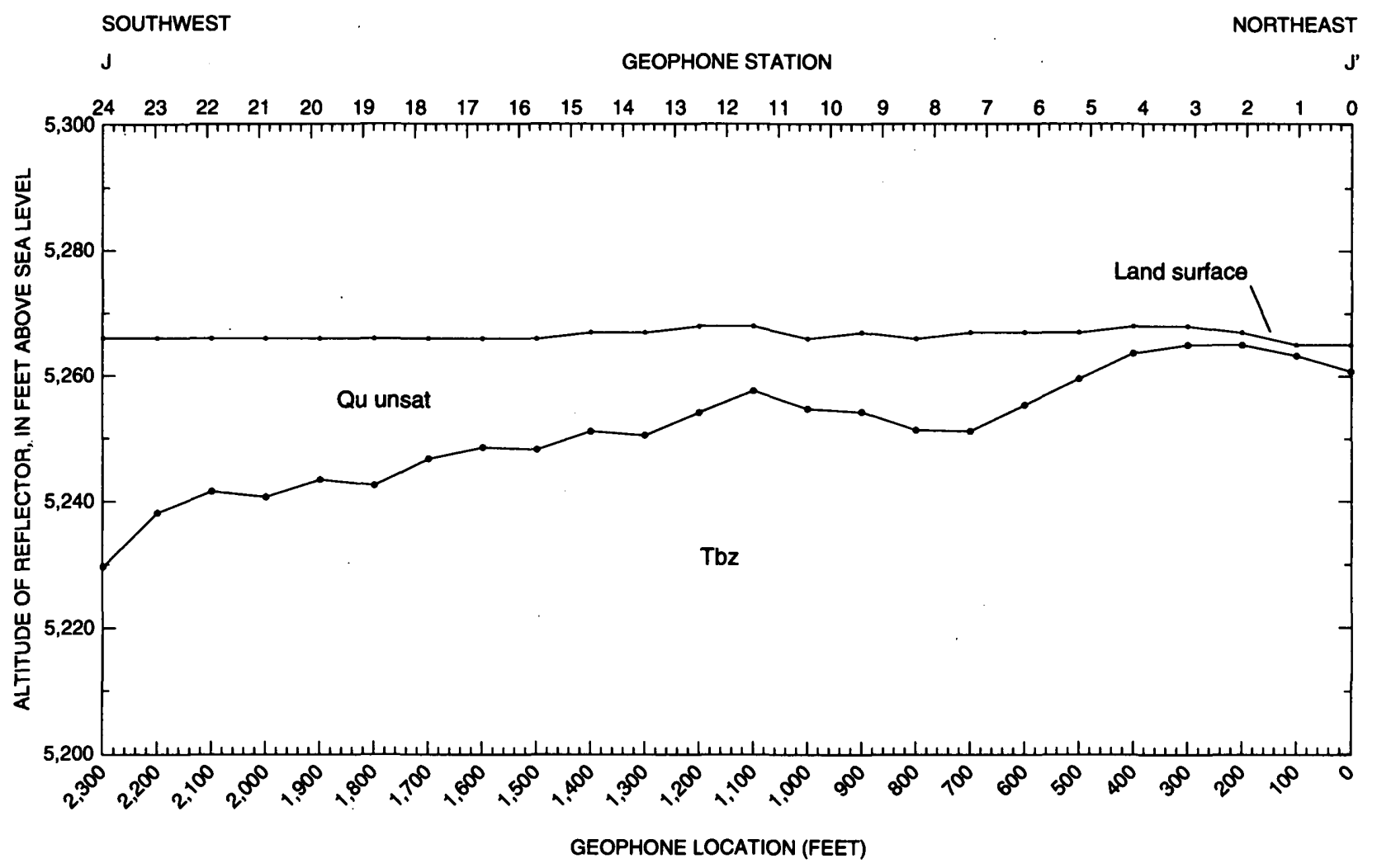

Figure 8. Geophysical profiles determined from seismic-refraction data. Lines of section are shown in figure 7 (Continued).

Deep refractors require long geophone lines. In addition, areas with thick unsaturated sections (greater than 30 or $40 \mathrm{ft}$ ) require a substantial amount of energy to propagate sound waves through the unsaturated materials. Where possible, shotpoints were positioned off each end of the geophone spread, with several shots for each spread. In some instances, the geophone and shotpoint array was limited owing to cultural interference, such as roadways, power lines, or bodies of water. Occasional ambient noise was a problem, either from wind, traffic, or, in one area, a large talc production plant.

\section{Results of the Seismic-Refraction Surveys}

The quality of seismic-refraction data collected is sufficient for interpretation. The Quaternary-Tertiary contact was identified to better correlate contacts defined by well-log data and the geophysical data, and to provide some consistency between the two sets of data. The contact is defined and used in the seismic- refraction survey and is used as a reference in the crosssectional ground-water flow model presented later in the report. Locating the Quaternary-Tertiary contact showed that many highly productive areas of the aquifer previously considered to be in Quaternary deposits were in fact in Tertiary deposits. Differentiation was based primarily on the seismic velocities associated with the Quaternary unconsolidated alluvial deposits and the semi-consolidated and consolidated Tertiary deposits. The profiles constructed from the surveys indicate that the depth to the contact generally is shallower than previously thought.

Overall, seismic-refraction data were consistent with well-log data and were particularly useful in determining depths to Tertiary deposits. Profiles of the 10 hydrogeologic sections interpreted from the surveys conducted are shown in figure 8. Bedrock was identified in four profiles. Paleozoic carbonates were identified in section C-C' and Archean gneiss was identified in section E-E'. Both of these sections are located along or near the margins of the Blacktail Deer Creek 
valley. Tertiary volcanic rocks were identified in section I-I' located in the northwestern part of the study area (fig. 7). Depth to bedrock near the center of the study area was greater than could be determined using the seismic-refraction technique. The water table was not detected in 5 of the 10 surveys conducted. The seismic velocity of the Tertiary deposits generally is greater than or equal to the unconsolidated water-table aquifer; therefore, the Tertiary deposits masked detection of the water table in areas where depth to water and the Tertiary deposits was very shallow. The water table is identified in profiles B-B', C-C', E-E', F-F', and I-I'.

Line of section A-A' is located northeast of the town of Barretts along the Beaverhead River (fig. 7). Well-log data obtained from the nested wells installed northeast of A-A' (wells 92-32 and 92-33) indicate alluvial gravel, sand, and small boulders to a depth of about 40-50 $\mathrm{ft}$ below land surface. Depth to the Quaternary-Tertiary contact, interpreted from the seismicrefraction data, ranges from about $37 \mathrm{ft}$ near the northeast end of the section to about $9 \mathrm{ft}$ near the southwest end (fig 8a). The Bozeman Group and related valleyfill deposits (Tbz) of Tertiary age underlie the Quaternary deposits, which consist of alluvium. The Tertiary deposits are more indurated and cemented than the overlying Quaternary deposits. The contact between Tbz and Tertiary volcanic rocks (Tvu), if present, was deeper than seismic refraction could identify. The water table was not identified in this survey.

Line of section B-B' is located about $500 \mathrm{ft}$ northeast of section $A-A^{\prime}$ and extends parallel to the Beaverhead River (fig. 7). Well-log data obtained from wells installed near the section (well 92-32 and 92-33) indicate the Quaternary-Tertiary contact is about $75 \mathrm{ft}$ below land surface. Seismic-refraction data indicate the depth to the interface ranges from about $76 \mathrm{ft}$ near the east end of the section to about $108 \mathrm{ft}$ near the west end (fig. 8b). Tbz was identified underlying the Quaternary deposits, which consist of alluvium. The water table, located in Quaternary deposits, ranged from about 8 to $10 \mathrm{ft}$ below land surface.

Line of section C-C' is located near the mouth of Sheep Creek Canyon (fig. 7). Well-log data obtained from 2 wells completed in bedrock (wells W-38 [376 ft in depth] and 92-7 [226 ft in depth]) (table 1) indicate that the top of Paleozoic carbonates ranges from about 150 to $160 \mathrm{ft}$ below land surface. Quaternary deposits, consisting of alluvial-fan deposits and alluvium, immediately overlie the Paleozoic bedrock in this area. Seismic-refraction data indicate the Quaternary-Paleozoic contact ranges in depth from about $62 \mathrm{ft}$ below land surface near the mouth of the canyon to about $133 \mathrm{ft}$ below land surface near the north end of the profile (fig. $8 \mathrm{c})$. The deeper reflector (reflection from the bedrock) had an average compressional velocity of about 12,000 $\mathrm{ft} / \mathrm{s}$ (table 3), which would confirm the Paleozoic bedrock described in well logs. The carbonate bedrock is possibly a limestone of the Madison Group of Mississippian age. The seismic refraction data also show evidence of a fault located near the south end of the section which closely coincides with a fault mapped in this area by Ruppel and others (1993) (fig. 3). The water table was not identified by seismic refraction in this survey but was inferred from well water-level data.

Line of section D-D' is located in the upper part of the Blacktail Deer Creek valley on the east side of the creek (fig. 7). Well-log data obtained from well 912 located near the west end of the section indicates a well-graded sand with silt and gravel to a silty sand and gravel to a depth of $22.5 \mathrm{ft}$. Seismic refraction data indicates the Quaternary-Tertiary contact ranges from about $24 \mathrm{ft}$ in depth near the west end of the section to about $45 \mathrm{ft}$ near the east end (fig. 8d). Tbz immediately underlies the Quaternary deposits, which consist of alluvium. The Tbz-Tvu contact, if present, was not identified in this survey. The water table was not identified in this survey.

Line of section E-E' is located on the west side of Blacktail Deer Creek and parallel to the East Bench Canal in the lower part of the Blacktail Deer Creek valley (fig. 7). Well-log data obtained from wells 91-7 and 92-14 located along the northern side of the section indicate Tertiary deposits $(\mathrm{Tbz})$ are located near the land surface (fig. 8e). A thin layer of Quaternary deposits (alluvium) overlie Tbz. A deeper reflector at about $525 \mathrm{ft}$, with an average compressional velocity of about $14,000 \mathrm{ft} / \mathrm{s}$ (table 3), indicates that Archean gneiss (Ag) bedrock probably underlies Tbz. Tru was not identified in this survey. Well-log data do not extend to these depths to verify the interpretation; however, the gneiss is visible in outcrop east of the section. The water table, located in Quaternary deposits, ranges from about 1 foot below land surface near the southwest end of the section to about $15 \mathrm{ft}$ below land surface near the northeast end. 
Line of section F-F' is located near the center of the Beaverhead River valley along Poindexter Slough (fig. 7). Well-log data obtained from wells 92-21 and 92-22, located near the south end of the section, indicate a silty, saturated clay about $20 \mathrm{ft}$ above Tertiary deposits (Tbz). Seismic-refraction data indicate the Quaternary-Tertiary contact ranges from about $21 \mathrm{ft}$ below land surface near the south end of the section to about $35 \mathrm{ft}$ near the north end (fig. 8f). Tbz immediately underlies the Quaternary deposits, which consist of alluvium. Well-log data show the aquifer extending to at least $485 \mathrm{ft}$ where a low permeability brownish silt or siltstone was described. This material is thought to be the consolidated lower part of Tbz. The Tbz-Tvu contact, if present, was too deep to identify using seismic refraction. The water table, located in Quaternary deposits, ranges from about $1 \mathrm{ft}$ to about $4 \mathrm{ft}$ below land surface.

Line of section G-G' is located west of Dillon on the northwest side of Interstate 15 (fig. 7). Well-log data obtained from wells 92-30 and 92-16 indicate a shallow, semi-consolidated deposit overlying an extrusive andesitic volcanic rock deposit. Seismic-refraction data indicate the Quaternary-Tertiary contact ranges from about $5 \mathrm{ft}$ below the land surface near the northwest end of the section to about $45 \mathrm{ft}$ below land surface near the southeast end (fig. $8 \mathrm{~g}$ ). The data indicate that the semi-consolidated deposits are Tertiary in age (Tbz), based on a seismic velocity of more than 8,000 $\mathrm{ft} / \mathrm{s}$. The average velocity for $\mathrm{Tbz}$ is about $7,400 \mathrm{ft} / \mathrm{s}$ (table 3 ) and the volcanic rocks are a high-velocity reflector with a velocity of about $12,000 \mathrm{ft} / \mathrm{s}$. Well-log data indicate that the contact is most likely Tbz-Tvu. The Tbz-Tvu contact ranges in depth from about $117 \mathrm{ft}$ near the northwest end of the section to about $475 \mathrm{ft}$ near the center of the section to about $395 \mathrm{ft}$ near the southeast end. The water table was not identified in this survey.

Line of section H-H' is located southwest of Dillon on the southeast side of Interstate 15 (fig. 7). Seismic-refraction data indicate the Quaternary-Tertiary contact ranges in depth from about 6 to $13 \mathrm{ft}$ below land surface (fig. $8 \mathrm{~h}$ ). Average seismic velocity in this layer was about $6,000 \mathrm{ft} / \mathrm{s}$, which is consistent with the range of velocities measured in Tertiary deposits in the study area. No well-log lithologic data were available to confirm seismic-refraction data. The Tbz-Tvu contact noted in section G-G' was not identified in this section; thus, the contact, if present, probably is greater than
$600 \mathrm{ft}$ in depth. The water table was not identified in this survey.

Line of section I-I' is located about 2 to 3 miles up Rattlesnake Creek Valley on the northern side of Rattlesnake Creek and State Highway 278 (fig. 7). Well-log data were not available within about a mile radius of the section. Well-log data obtained from the nearest wells available (wells W9 and W13) indicate Quaternary deposits consisting of sand and gravel overlying Tertiary deposits. The Quaternary deposits consist of glacial outwash (Qo) and alluvium (Qa) (fig. 3). Seismic-refraction data indicate that the Quaternary-Tertiary contact ranges from 48 to $110 \mathrm{ft}$ in depth (fig. 8i). These depths are comparable to well-log data. A deeper reflector indicates a Tbz-Tvu contact ranging from about $168 \mathrm{ft}$ near the northeast end of the section to about $430 \mathrm{ft}$ near the southwest end. Although welllog data do not confirm this contact, volcanic rocks are visible in outcrop near the northwest end of the section. The water table was not identified by seismic refraction in this survey but was inferred from well water-level data.

Line of section J-J' also is located about 2 to 3 miles up Rattlesnake Creek Valley south of Rattlesnake Creek and State Highway 278 (fig. 7). As with section I-I', well-log data from well W9 indicate Quaternary deposits consisting of sand and gravel overlying Tertiary deposits. Along this section, the Quaternary deposits consist of glacial outwash (Qo) and alluvium (Qa) (fig. 3). The Quaternary-Tertiary contact ranges in depth from about 2 to $36 \mathrm{ft}$ below land surface (fig. 8j). The deeper Tbz-Tvu contact, if present, was not evident in this survey, again because the contact was probably greater than $600 \mathrm{ft}$ in depth. The water table was not identified in this survey.

\section{WATER-QUALITY ANALYSIS}

Ground- and surface-water samples collected by the USGS followed guidelines and quality-control procedures described in Knapton (1985) and Knapton and Nimick (1991). Field quality-assurance practices involved calibration of all field meters and probes and cleaning of sampling equipment prior to all site visits. Immediately prior to each sampling, meters and probes were recalibrated. Samples collected by the USGS were analyzed by the Montana Bureau of Mines and Geology (MBMG) laboratory in Butte, Montana. 
Ground- and surface-water samples collected by the University of Montana (UM) were analyzed at the UM laboratory in Missoula, Montana (William Uthman, written commun., 1995).

Ground- and surface-water quality data were used to help develop the conceptual model of the ground-water flow system in the study area. Variations in the data were used to differentiate sources of water in different parts of the aquifer. Water-quality samples were collected from a total of 66 wells, 2 springs, and 5 surface-water sites from 1991 and 1993-94 by the USGS and UM. Ground- and surface-water sampling sites in the Blacktail Deer Creek area and the surficial drainage pattern in the study area are shown in figure 4. Water samples were collected by the USGS as part of two different studies. Water samples were collected from seven wells and one spring in August 1991 as part of the Northern Rocky Mountains Intermontane Basins Regional Aquifer Systems Analysis (RASA) study. As part of the present study, ground- and surface-water samples were collected from 39 wells, 1 spring, and 4 surface-water sites in August-September 1993 or in April-May 1994. The physical properties, inorganic constituents, and trace elements analyzed in samples collected during both sampling periods are listed in table 4. Twenty-one ground-water samples and two surface-water samples were collected by the UM in November-December 1993. These samples primarily were collected from domestic, irrigation, and stock wells located in the lower Blacktail Deer Creek, lower Beaverhead River, and lower Rattlesnake Creek valleys. The physical properties, inorganic constituents, and trace elements analyzed in the samples are listed in table 5 .

The chemical quality of water is characterized by its dissolved ionic composition. The major cations are calcium, magnesium, and sodium; and major anions are bicarbonate, sulfate, and chloride. In this report, ionic compositions are used to describe the general type of water, with a dominant cation or anion representing more than 50 percent of the total concentration of cations or anions. If no cations or anions are dominant, ionic compositions are described in decreasing order of occurrence for the major cations and anions. The ionic compositions of selected chemical analyses are presented graphically (Stiff, 1951) in figure 9.

Of the ground- and surface-water samples collected for this type of analysis, most samples show a calcium-bicarbonate water type (fig. 9). Water collected from spring SP1, issuing from the limestone bedrock, and well 92-7 (both sites located near the mouth of Sheep Creek Canyon) was a calcium bicarbonatesulfate type. Water collected from two of the deeper wells $(92-8,92-9)$ along a flow path (line of section $\mathrm{K}$ K', fig. 6) north of the recharge area along the valley margin near Sheep Creek Canyon also had a calcium bicarbonate-sulfate type. Water collected from well $92-$ 21 located near the north part of the section near the Beaverhead River had a calcium-sodium bicarbonate type. Water issuing from spring SP2, located in the upper part of Blacktail Deer Creek valley, had a calcium-magnesium bicarbonate type, which was distinct from all other samples collected. Because of this distinctiveness, an assumption is made that the water issues from Archean gneiss.

Water-quality differences also were observed between samples collected near Blacktail Deer Creek and the southwestern and western parts of the study area (tables 4 and 5). Specific conductance values were less than $600 \mu \mathrm{S} / \mathrm{cm}$ near Blacktail Deer Creek and generally were greater than $600 \mu \mathrm{S} / \mathrm{cm}$ in samples collected in the southwestern part of the valley. Groundwater temperatures measured in samples in the southwestern and western parts of the study area generally were greater than temperatures measured in samples near Blacktail Deer Creek. The higher temperatures were measured in wells $92-7\left(21.5^{\circ} \mathrm{C}\right), \mathrm{W} 38\left(22.0^{\circ} \mathrm{C}\right)$, and spring SP1 $\left(20.5^{\circ} \mathrm{C}\right)$ (table 4, fig. 4). The higher temperatures are probably a result of warmer water entering the basin-fill aquifer from the underlying limestone bedrock. The temperature of water sampled from spring SP2 was $6.5^{\circ} \mathrm{C}$.

Concentrations of some trace elements in samples collected along Blacktail Deer Creek were different than concentrations in samples collected in the southwestern and western parts of the study area. Concentrations of lithium and strontium (figs. 10 and 11) generally were greater in samples collected from the southwestern part of the study area. Barium concentrations (fig. 12) were greater in samples collected along Blacktail Deer Creek and in the northern part of the study area. These relations indicate that ground water in the southwestern part of the valley and in the Blacktail Deer Creek area has two distinct sources. 


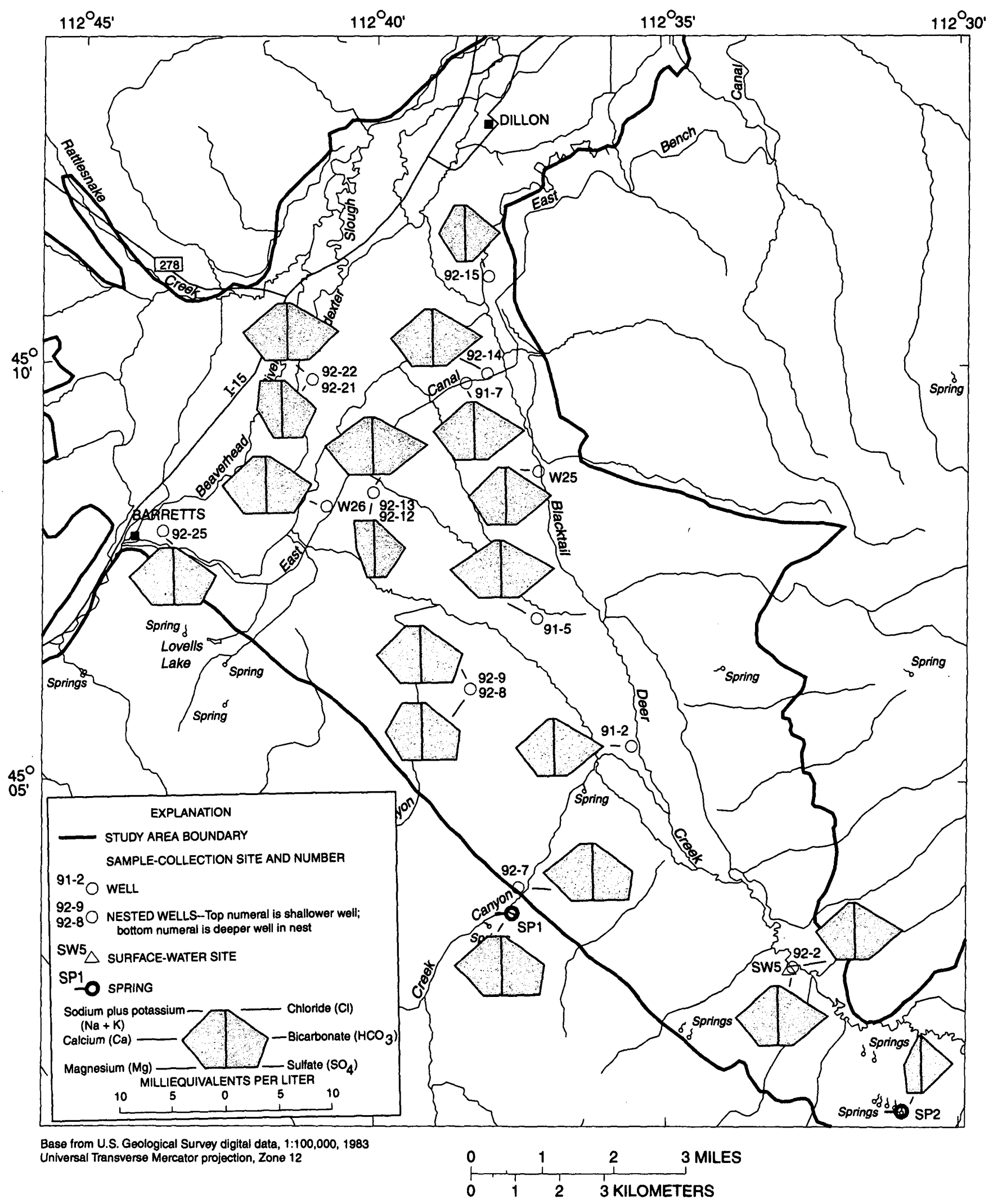

Figure 9. Stiff diagrams for water samples collected from selected wells, springs, and surface-water sites near Dillon, Montana, 1991 and 1993-94. 


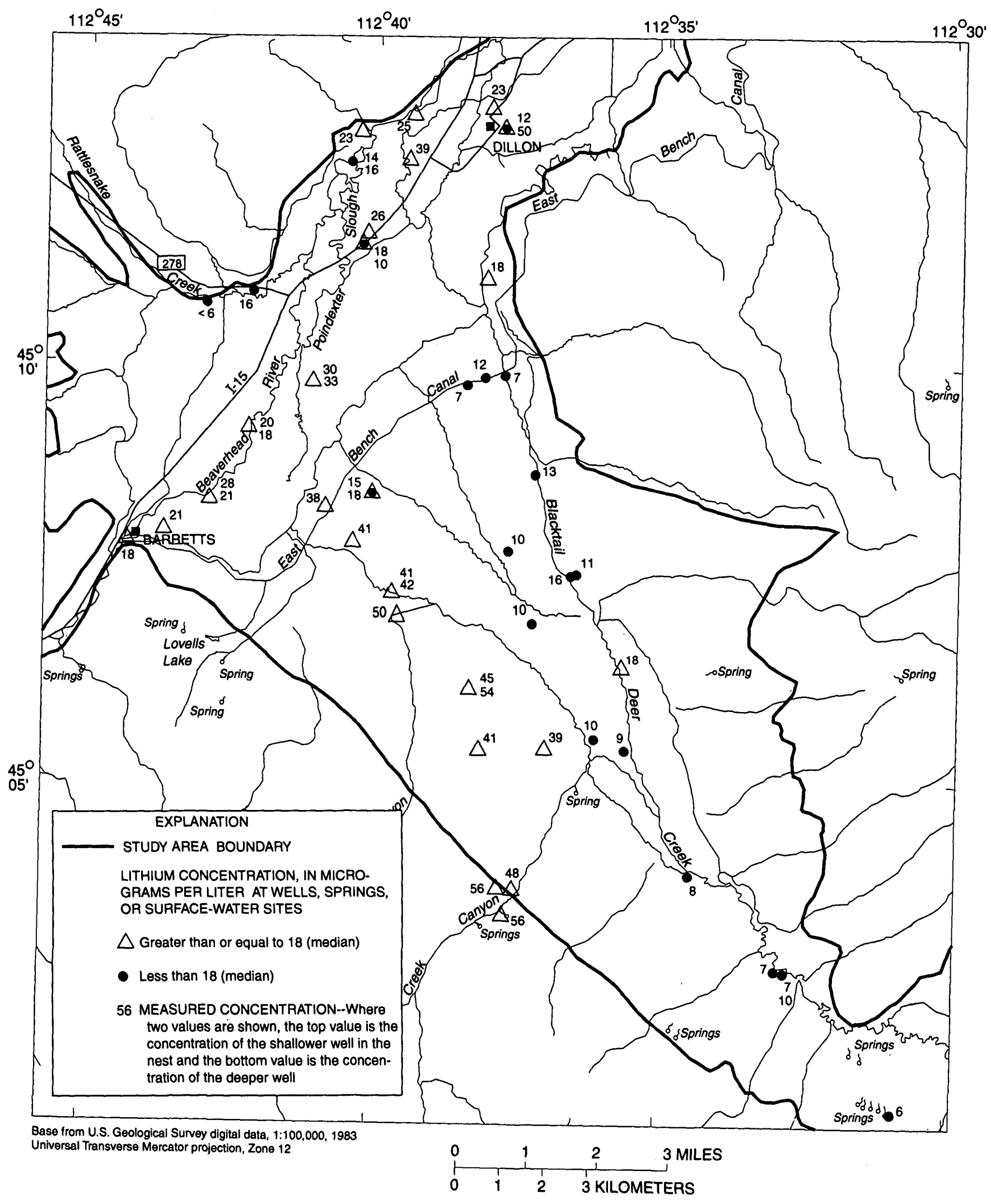

Figure 10. Lithium concentrations in water from wells, springs, and surface-water sites near Dillon, Montana. 


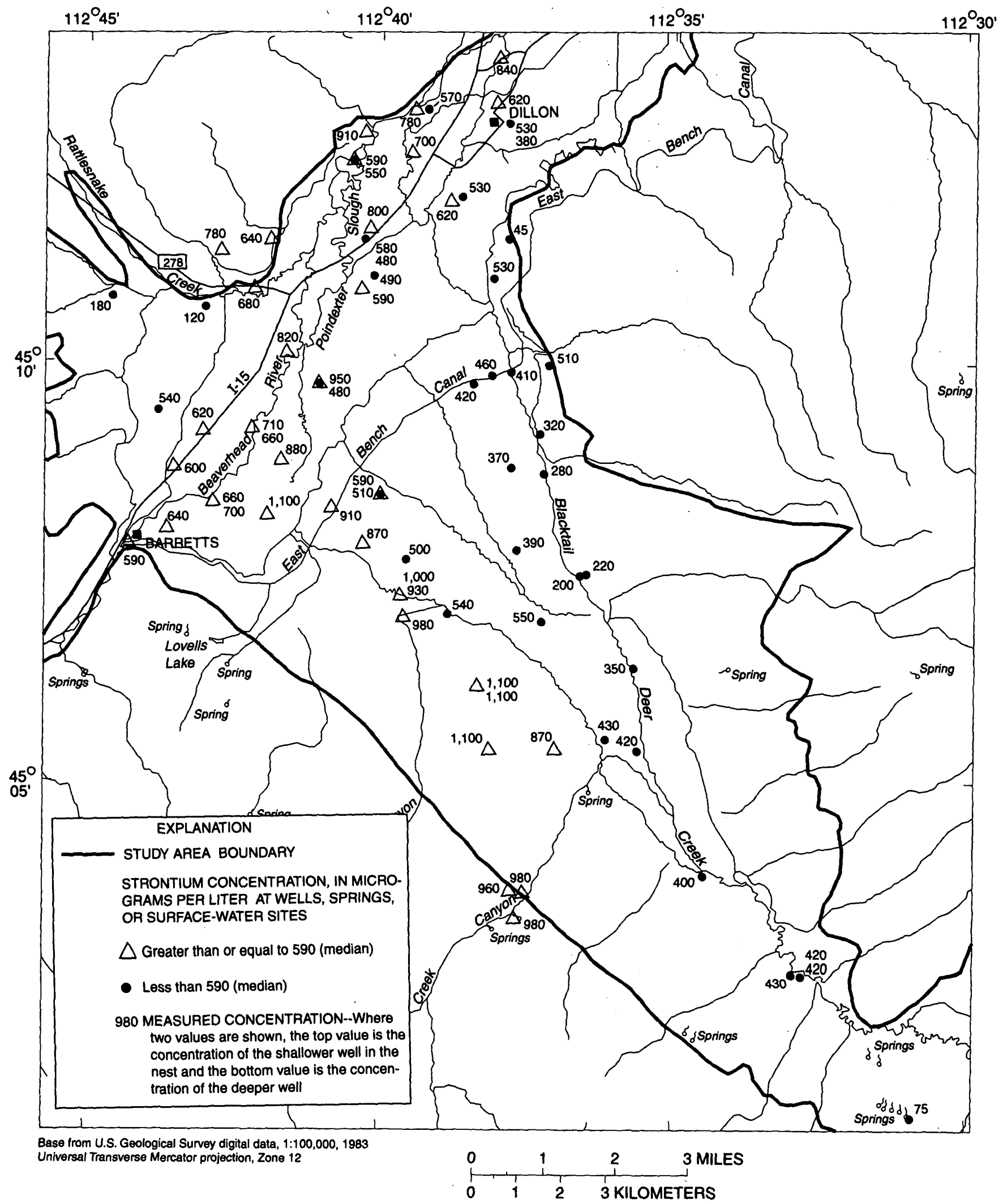

Figure 11. Strontium concentrations in water from wells, springs, and surface-water sites near Dillon, Montana. 


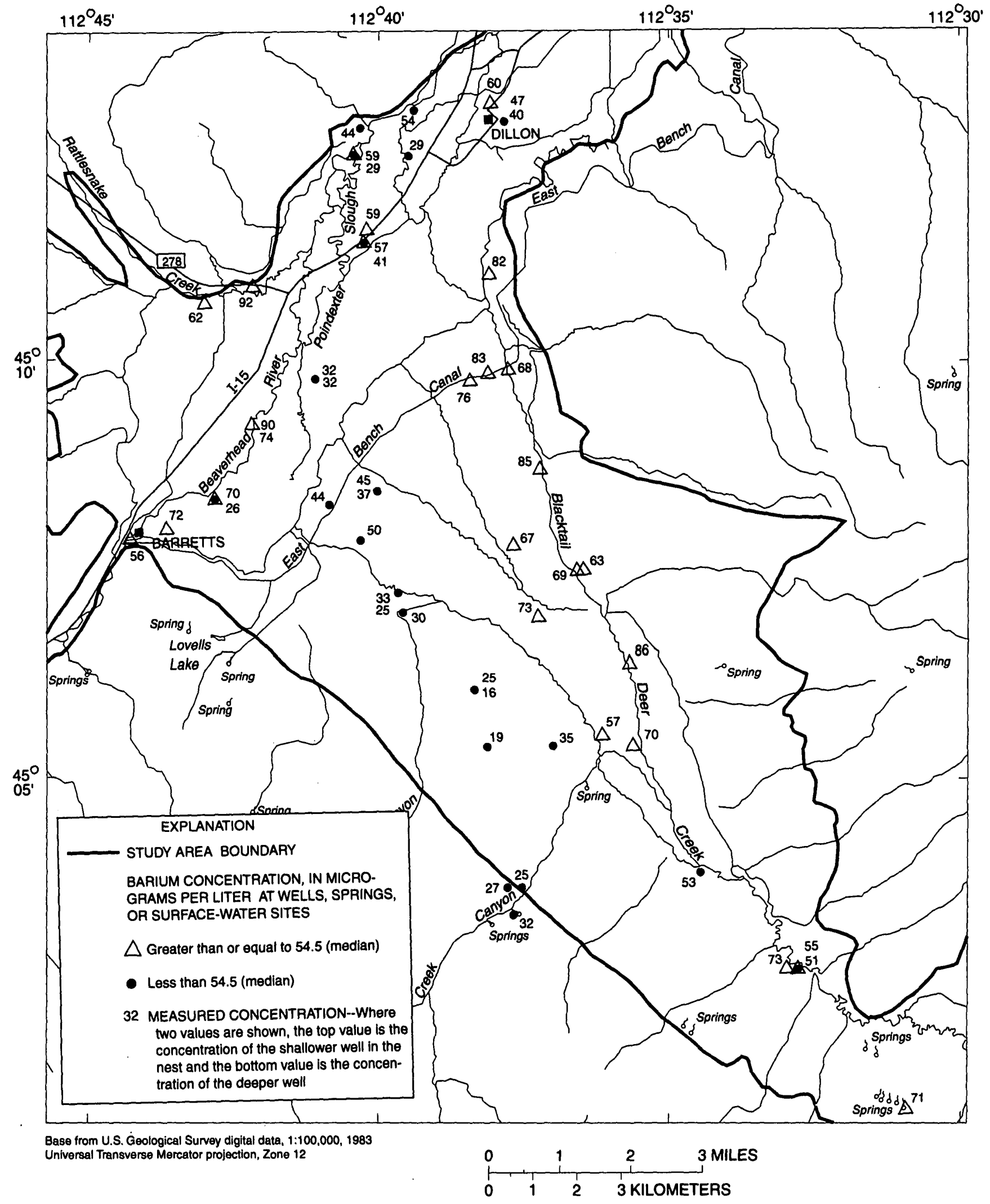

Figure 12. Barium concentrations in water from wells, springs, and surface-water sites near Dillon, Montana. 


\section{TRANSIENT-TRACER ANALYSIS}

Conventional physical, chemical, and isotopic methods for defining ground-water flow paths, travel times, and recharge rates have limitations. Digitalmodeling techniques, which are commonly used to define ground-water flow systems, also have limitations; if not adequately constrained, the techniques may not necessarily result in unique or correct solutions. Transient tracers such as chlorofluorocarbons (CFCs) and tritium $\left({ }^{3} \mathrm{H}\right)$ have been used to evaluate flow systems with relative success. A better understanding of ground-water flow systems occurs when transient tracers are used in conjunction with conventional and modeling techniques. For examples of this type of work, the reader is referred to Ekwurzel and others (1994), Cook and others (1995), and Szabo and others (1996).

\section{Chlorofluorocarbon (CFC) Dating Technique}

CFCs are synthetic organic compounds, first manufactured in the 1930's, that are used as refrigerants, aerosol propellants, cleaning agents, solvents, and blowing agents in the production of foam rubber and plastics. CFCs include the compounds trichlorofluoromethane $\left(\mathrm{CCl}_{3} \mathrm{~F}\right.$ or $\left.\mathrm{CFC}-11\right)$, dichlorodifluoromethane $\left(\mathrm{CCl}_{2} \mathrm{~F}_{2}\right.$ or $\left.\mathrm{CFC}-12\right)$, and trichlorotrifluoroethane $\left(\mathrm{C}_{2} \mathrm{Cl}_{3} \mathrm{~F}_{3}\right.$ or $\left.\mathrm{CFC}-113\right)$. CFCs have been accumulating in the atmosphere for six decades, and the build-up of these compounds has been monitored worldwide since 1977. Estimates of atmospheric CFC concentrations prior to 1977 were developed by McCarthy and others (1977) and Cunnold and others (1986). The temporal evolution of atmospheric concentrations is discussed in detail in Busenberg and others (1993). Once in the atmosphere, CFCs partition into water that is in contact with the atmosphere.

CFC-11 and CFC-12 can be detected in post1940 ground water using methods developed by Thompson and Hayes (1979) and refined by Busenberg and Plummer (1991, 1992). CFC-113 can be detected in post-1966 ground water (E. Busenberg, U.S. Geological Survey, written commun., 1993). Based on solubility relations (Warner and Weiss, 1985), concentrations of CFCs in ground water can be used as indicators of the apparent age of ground water. The apparent age is defined as the time since the water was isolated from the atmosphere. Quantitative application of this method assumes, however, that the CFC concen- trations in ground water are not affected by mixing, contamination, sorption, or degradation. For more examples of the use of CFCs to estimate residence times and velocity, and to trace contamination, the reader is referred to Thompson and others (1974), Schultz and others (1976), Thompson and Hayes (1979), Busenberg and others (1991,1992), Busenberg and Plummer (1993), Dunkle and others (1993), Cook and others (1995), and Katz and others (1995).

\section{Tritium and Helium-Isotope Dating Technique}

Tritium $\left({ }^{3} \mathrm{H}\right)$ has been introduced into the environment worldwide in concentrations far exceeding natural concentrations as a result of atmospheric testing of thermonuclear devices, primarily in the 1950's and early 1960's (Michel, 1989). Tritium input peaked in 1963 , then began decreasing as a result of a test ban. Tritium can be used to determine pre- and post- 1953 water, and can be used as an absolute time marker in hydrologic studies if peak tritium concentrations associated with the circa-1963 peak atmospheric concentration can be located (Egboka and others, 1983; Robertson and Cherry, 1989). However, because of radioactive decay and hydrodynamic dispersion, the tritium peak in ground water is becoming more difficult to identify. By using the combination of tritium and its decay product tritiogenic helium-3 $\left({ }^{3} \mathrm{He}_{\text {trit }}\right)$, which together form a conservative tracer, the 1963 peak atmospheric concentration can be more easily identified, and an apparent age can be calculated that is independent of the tritium input function, which may be unknown at a particular site. Determining the apparent age of ground water using tritium in combination with its decay product tritiogenic ${ }^{3} \mathrm{He}$ is referred to as the tritium and helium isotope $\left({ }^{3} \mathrm{H}-{ }^{3} \mathrm{He}\right)$ dating technique. For more information concerning the use of this technique in hydrologic studies, the reader is referred to Poreda and others (1988), Schlosser and others (1988, 1989, 1994), Solomon and Sudicky (1991), and Solomon and others (1992, 1993, and 1995). Quantitative application of the method assumes that the tritiogenic ${ }^{3} \mathrm{He}$ remains confined, that mixing and hydrodynamic dispersion are minimized, and that terrigenic helium concentrations do not dominate the helium component. Terrigenic helium can include inputs of radiogenic helium resulting from decay of $U$ and $\mathrm{Th}$ series elements in the aquifer, inputs of nucleogenic ${ }^{3} \mathrm{He}$ produced by ${ }^{6} \mathrm{Li}\left(\mathrm{n}_{1} \mathrm{a}\right)^{3} \mathrm{H}$ reactions, and 
inputs of mantle or primordial helium diffusing up from great depths (Shapiro, 1998).

\section{Sample Collection and Laboratory Analysis}

Representative ground- and surface-water samples were collected from selected wells, springs, and surface-water sites in the basin-fill aquifer for CFC and tritium and helium-isotope analysis. Most groundwater samples were collected from wells with open (perforated or screened) intervals of less than $10 \mathrm{ft}$. Perforated or screened intervals for wells W3, W25, W26, and W32 are unknown and intervals for wells $\mathrm{W} 2, \mathrm{~W} 35$, and W38 range from 26 to $280 \mathrm{ft}$ (table 1). Water was purged from wells until at least two casing volumes of water were evacuated and the monitored field characteristics (specific conductance, $\mathrm{pH}$, water temperature, and dissolved oxygen) were stabilized. When possible, ground- and surface-water samples were collected using a pump with a copper-tube discharge line to ensure samples were not contaminated. In wells where water levels were greater than $100 \mathrm{ft}$ below land surface, a larger pump with a 2 -in. diameter polyvinylchloride (PVC) drop pipe was used to pump water, both to purge the wells and to obtain water samples.

Ground-water samples were collected from 6 wells (W2, W3, W25, W32, W35, and W38) for CFC analysis in 1991 as part of a reconnaissance study, and samples were collected from 39 additional wells from August 1993 through April 1994 (table 6). After these samples were analyzed, 17 of these 39 wells were resampled for $\mathrm{CFC}$ and ${ }^{3} \mathrm{H}-{ }^{3} \mathrm{He}$ analysis. These 17 wells were selected to represent different conditions present in the aquifer and to help resolve questions about the results of the previous CFC analyses. Surface-water samples were collected from two springs and two surface-water sites.

Ground- and surface-water samples were collected for CFC analysis using the apparatus and methods described in Busenberg and Plummer (1992). Up to five ampules were collected at each site (table 6). While the samples were being collected, field characteristics were monitored and measured in a flowthrough chamber. The field characteristics measured during sampling are listed in table 7. Samples collected for CFC analysis from two springs (SP1, SP2) and two surface-water sites (SW2, SW5) were collected by thoroughly flushing the ampules with sample water, using a clamp to hold the top of the ampule, and quickly sealing the glass ampule with a welding torch. All samples were analyzed by the USGS in Reston, Virginia.

Samples for ${ }^{3} \mathrm{H}_{-}{ }^{3} \mathrm{He}$ dating were collected at 17 sites (table 8). The samples were collected in copper tubes and sealed with stainless steel pinch-off clamps after the sample was collected. Two tubes were collected at each site. The samples were sent to the Lamont-Doherty Earth Observatory Noble Gas Facility, Columbia University, Palisades, New York, for extraction and analysis. Details of the extraction and measurement procedure are discussed in Shapiro and others (1997). Duplicate samples were analyzed at 5 of the 17 sites.

Both the $\mathrm{CFC}$ and ${ }^{3} \mathrm{H}-{ }^{3} \mathrm{He}$ dating techniques require an estimate of the recharge temperature of the water. The recharge temperature is the temperature of the water in equilibrium with the atmosphere at the time recharge occurred. Recharge temperatures were determined from the relation between the mean annual air temperature and the estimated altitude of the recharge area and from the concentrations of dissolved gases in samples collected from selected wells.

Recharge altitudes were estimated by determining potential recharge areas using the flow directions indicated on the potentiometric-surface map (fig. 6). Recharge to the limestone bedrock near Sheep Creek Canyon was estimated to occur at about 6,500 to 8,000 $\mathrm{ft}$ above sea level. Recharge to the basin-fill aquifer near Blacktail Deer Creek was assumed to occur within the valley. Annual air temperature data for the weather station at Dillon and nine other stations located in southwestern Montana were used to establish a linear relation between the mean annual air temperature and the altitude. Estimated recharge water temperatures ranged from 0.5 to $6.2{ }^{\circ} \mathrm{C}$.

\section{Concentrations of dissolved gases in ground} water can be used as good indicators of the recharge temperature of the water (Heaton, 1981; Heaton and Vogel, 1981). Dissolved gases were measured in samples collected from selected wells to help determine recharge temperatures of the water. Samples were collected from 10 wells using the methods described in Busenberg and others (1993). The samples were analyzed by the USGS in Reston, Virginia. The recharge water temperatures determined from the dissolved-gas analysis were compared to water temperatures esti- 
mated using the mean annual air temperature/altitude relation described in the previous two paragraphs. In general, the recharge temperature estimates based on the temperature/altitude relation are consistent with the dissolved-gas analysis. To ensure consistency, the temperature/altitude relation was used to estimate recharge temperatures for all samples.

\section{Discussion of Tracer Results}

The goal of the tracer analyses was to determine apparent recharge dates of water collected from wells, springs, and surface-water sites in the study area. CFC and ${ }^{3} \mathrm{H}-{ }^{3} \mathrm{He}$ dating techniques were used together to determine apparent ages of ground water in the basinfill aquifer. Because CFC data are available from 49 ground- and surface-water sites (table 6), and because ${ }^{3} \mathrm{H}-{ }^{3} \mathrm{He}$ data are sparse (table 8 ), CFC dating was the primary technique used to estimate apparent groundwater ages. As a result of the sparsity of data, the ${ }^{3} \mathrm{H}-{ }^{3} \mathrm{He}$ data were used primarily to help resolve discrepancies in apparent ages estimated from the three CFC compounds (CFC-11,CFC-12, and CFC-113).

\section{CFC Data}

The results of the CFC analysis are given in table 6. Where possible, recharge dates were determined for each ampule analyzed using the CFC concentration and recharge temperature. Recharge dates were determined to be modern water $(M)$ in eight samples collected at four ground-water sites (table 6). Modern water is defined as water in which the CFC concentrations were near concentrations of CFC in the air in equilibrium with atmospheric $\mathrm{CFC}$ levels at the time of sampling. Recharge dates could not be determined in 17 samples collected at 6 ground-water sites that were contaminated (C) with CFC's. Samples were considered contaminated when the measured CFC concentrations were greater than CFC levels in the atmosphere at the time of sampling. For samples where no CFCs were detected, the recharge date is reported as being greater than the indicated date.

Discussion of the apparent ages determined using the three different CFC tracers is best accomplished by comparing the mean-apparent ages for the first sample taken at each site. Mean-apparent ages were determined for each CFC compound using all ampules that were analyzed. If any of the ampules had recharge dates quantified only as being greater than some age, the mean-apparent age is defined as being older than the mean determined from all of the ampules. The mean-apparent ages for sites that were resampled in 1994 were consistent with the ages determined from the water samples taken in 1993. The mean-apparent age from the first sample at a site is used as the mean-apparent age for the site in the remainder of this report. Mean-apparent ages for the tracers at a site were not compared if one of the tracers could not be assigned a specific date (if the meanapparent age is given as greater than some age).

At the 29 sites where mean-apparent recharge dates could be quantified using all three CFC compounds, all three recharge dates were within 5 years of each other at only 6 of the sites ( 21 percent). In most instances these age differences are due to the meanapparent CFC-11 ages being older than the CFC-12 and CFC-113 ages.

Mean-apparent ages for the CFC-11 and CFC-12 are available at 43 sites. At 16 of those sites the CFC11 and CFC-12 ages differ by more than 5 years. Apparent ages determined using CFC-11 were greater than those determined using CFC-12 at all but one of these sites (well $92-8$ is the only exception). The greatest CFC-11 and CFC-12 age difference was 11.3 years at well 92-2. Many of these sites are located near Blacktail Deer Creek or the Beaverhead River. CFC11 and CFC-12 apparent ages match closely at sites in the southwestern part of the study area (from about well 92-7 north to well 92-11).

The CFC-12 and CFC-113 ages were within 5 years of each other at 24 of 29 sites where both ages were quantified. CFC-12 and CFC-113 apparent ages are consistent with the tritium and helium data available (which will be discussed in the next section). This consistency indicates that the concentration of trichlorofluoromethane (CFC-11) in certain parts of the basinfill aquifer might have been attenuated, causing the older CFC-11 mean-apparent ages.

Concentrations of CFC compounds in an aquifer can be decreased (making the water seem older than it really is) due to sorption and biodegradation. CFC-1/13 is more strongly sorbed onto organic material in the aquifer than are CFC-11 or CFC-12 (E. Busenberg, oral commun., 1995). Because CFC-113 apparent ages are consistent with the CFC-12 ages, sorption probably 
does not account for the low CFC-11 concentrations. CFC-11 biodegrades significantly faster than CFC-12 or CFC-113 under reducing conditions (E. Busenberg, oral commun., 1995). Biodegradation could explain the lower CFC-11 concentrations (and resulting older ages) in relation to CFC-12 and CFC-113 concentrations. However, reducing conditions in the ground water are not evident at any of the sites sampled (table 7). Dissolved-oxygen concentrations in water samples collected at all sites (table 7) averaged $5.9 \mathrm{mg} / \mathrm{L}$, and concentrations averaged $5.3 \mathrm{mg} / \mathrm{L}$ in samples collected at sites where CFC-11 apparent ages were greater than 5 years older than CFC-12 ages. Four of the five samples collected (wells 92-2, 92-23, 92-30, 92-33) having the largest differences between CFC-11 and CFC-12 ages, however, had dissolved-oxygen concentrations ranging from less than $0.1 \mathrm{mg} / \mathrm{L}$ to $3.1 \mathrm{mg} / \mathrm{L}$.

One possible explanation for the older CFC-11 apparent ages is that CFC-11 biodegradation is occurring as pore water moves through anoxic zones in the unsaturated zone above the aquifer. The lower dissolved-oxygen concentrations in parts of the aquifer may indicate biogenic activity in the soil zone. This activity could create anoxic zones in the unsaturated zone where CFC-11 could be biodegraded. Data are unavailable from the unsaturated zone to support this hypothesis. Therefore, the cause or causes of the differences between the CFC-11 and CFC-12 apparent ages could not be definitively determined.

\section{Tritium and Helium-Isotope Data}

The results of the tritium, helium-isotope and neon analyses are listed in table 8 . Of the 22 samples collected and analyzed, 2 had concentrations less than $1 \mathrm{TU}, 4$ had concentrations ranging from 12.59 to 17.90 TU, 12 had concentrations ranging from 19.63 to 30.63 TU, and 4 samples had no concentrations determined. Overall, tritium concentrations ranged from 0.03 to 30.63 TU. Tritium concentrations in five samples collected in the shallowest (18 to $61 \mathrm{ft}$ ) wells ranged from 17.90 to $23.18 \mathrm{TU}$ (table 8), averaging approximately $20 \mathrm{TU}$. This range is close to concentrations measured in modern precipitation in this area (Michel, 1989). Two wells (92-16 and 92-17) have low tritium concentrations ( 0.03 and $0.07 \mathrm{TU}$, respectively) indicating the presence of pre-1950's water at these locations. These two wells are located in the northern part of the study area near Dillon (fig. 4). Helium-4 $\left({ }^{4} \mathrm{He}\right)$ concentrations range from slightly above atmospheric equilib- rium, which would be $3.95 \times 10^{-8} \mathrm{ccSTP}^{-1}$ (cubic centimeters per gram at standard temperature and pressure), to values as high as $2.15 \times 10^{-7} \mathrm{ccSTP} \mathrm{g}^{-1}$. In samples where the ${ }^{3} \mathrm{H}-{ }^{3} \mathrm{He}$ ages could be determined, the $\Delta^{4} \mathrm{He}$, a measure of the ${ }^{4} \mathrm{He}$ supersaturation, ranges from 34 to 445 percent, with an average value of 138 percent, indicating the presence of excess ${ }^{4} \mathrm{He} . \delta^{3} \mathrm{He}$, the percent deviation of the ${ }^{3} \mathrm{He} /{ }^{4} \mathrm{He}$ ratio of a sample from an air standard of $1.384 \times 10^{-6}$ (Clarke and others, 1976), is large and positive (as great as 348.10 percent) in samples collected from wells with the highest tritium values, but negative (as low as $\mathbf{- 5 6 . 9 7}$ percent) in samples collected from wells with large excesses of ${ }^{4} \mathrm{He}$. $\Delta \mathrm{Ne}$, a measure of the neon supersaturation, averages 26 percent, which indicates that the large excess of ${ }^{4} \mathrm{He}$ is the result of terrigenic inputs and not excess air.

The results of the helium analyses indicate a significant source of terrigenic helium in the basin-fill aquifer that must be isolated in order to calculate the tritiogenic component of the ${ }^{3} \mathrm{He}$ budget (Schlosser and others, 1989). Terrigenic ${ }^{4} \mathrm{He}\left(\left[{ }^{4} \mathrm{He}\right]_{\text {ter }}\right.$ table 8) concentrations range from $2.32 \times 10^{-9}$ to $1.15 \times 10^{-7}$ $\operatorname{ccSTP~} \mathrm{g}^{-1}$; the greater concentration corresponds to samples collected from wells having large $\Delta^{4} \mathrm{He}$ values. The ${ }^{3} \mathrm{He} /{ }^{4} \mathrm{He}$ ratio of the terrigenic helium is estimated to be $2.8 \times 10^{-7}$ by calculating a terrigenic ratio from a sample collected from one well (92-17) that had a low tritium value ( $0.07 \mathrm{TU})$. For this well, the ${ }^{3} \mathrm{He}_{\text {ter }}$ concentration was determined by subtracting air and tritiogenic ${ }^{3} \mathrm{He}$ components from the measured ${ }^{3} \mathrm{He}$. The tritiogenic ${ }^{3} \mathrm{He}$ component was determined by assuming a pre-bomb tritium concentration in precipitation of $5 \mathrm{TU}$ minus the amount of tritium present when the sample was collected. The ${ }^{4} \mathrm{He}_{\mathrm{ter}}$ concentration was determined by subtracting the ${ }^{4} \mathrm{He}$ air components from the measured ${ }^{4} \mathrm{He}$ concentration (Schlosser and others, 1989). The ${ }^{3} \mathrm{He} /{ }^{4} \mathrm{He}$ ratio derived from well 92-17 might be more representative of the site than $2 \mathrm{x}$ $10^{-8} \mathrm{ccSTP}^{-1}$, the value often cited in the literature (Mamyrin and Tolstikhin, 1984).

$$
\left[{ }^{3} \mathrm{H}\right]+\left[{ }^{3} \mathrm{He}_{\text {trit }}\right] \text { concentrations and }{ }^{3} \mathrm{H}-{ }^{3} \mathrm{He}
$$
apparent ages were determined for four ground-water samples collected from three wells (wells 92-20, 92-32, and 92-33) (table 8). The concentrations and ages were determined without accounting for terrigenic helium because the terrigenic component was less than 5 percent of the equilibrium helium concentration in the samples. Accounting for the terrigenic helium does not substantially affect the apparent ages since the terri- 
genic component is so small. In addition, accounting for the terrigenic helium would add an additional source of error due to the use of neon data that have uncertainty. These samples are reported in the first section of table 8 under the heading "Not corrected." Plotting concentrations of neon in relation to concentrations of ${ }^{4} \mathrm{He}$ (fig. 13) shows that these samples cluster near the $5^{\circ} \mathrm{C}$ excess air line showing that within a given range of temperatures, the samples only are affected by the addition of excess air. These samples also show no increase in ${ }^{4} \mathrm{He}, \Delta^{4} \mathrm{He}$, or terrigenic ${ }^{4} \mathrm{He}$ in relation to depth or with increasing ages, indicating no effect of terrigenic helium.
In 11 samples collected from 8 wells, in which the terrigenic component of the helium budget was greater than 5 percent of the equilibrium helium concentration, the estimated terrigenic ratio and the measured neon concentrations were used to calculate the tritiogenic ${ }^{3} \mathrm{He}$ (Schlosser and others, 1989). Results of the analyses of these 11 samples are listed in table 8 under the heading "Corrected." Plotting concentrations of neon in relation to concentrations of ${ }^{4} \mathrm{He}$ (fig. 13), these 11 samples show a clear excess of ${ }^{4} \mathrm{He}$ in addition to excess air, indicating the addition of terrigenic helium. Overall, the 11 samples show a general increase in ${ }^{4} \mathrm{He}, \Delta^{4} \mathrm{He}$, and terrigenic ${ }^{4} \mathrm{He}$ in relation to depth, and also show an increase in terrigenic ${ }^{4} \mathrm{He}$ in

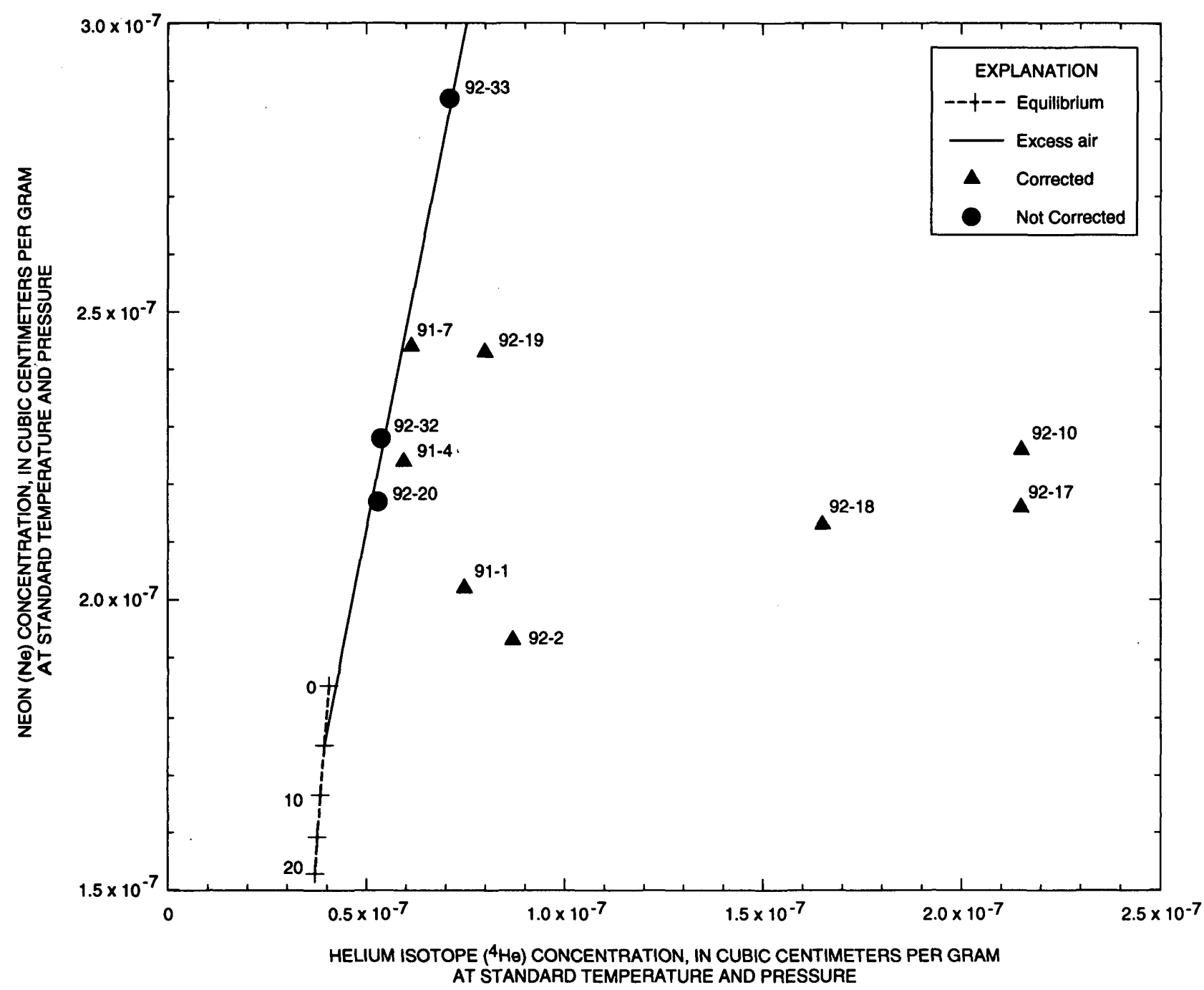

Figure 13. Neon and total ${ }^{4} \mathrm{He}$ concentrations (division of data into those with and without a correction for terrigenic helium is discussed in the text). Equilibrium concentration line determined for $0,5,10,15$, and 20 degrees Celsius. Excess air line determined using a temperature of 5 degrees Celsius, which is the average recharge temperature for the wells sampled for tritium and helium isotopes. 
relation to increasing age. These relations indicate a similar correlation between terrigenic ${ }^{4} \mathrm{He}$ in relation to depth, and terrigenic ${ }^{4} \mathrm{He}$ in relation to age. Because of the limited data, it is difficult to determine if the source of the terrigenic helium is diffusion from the earth's mantle or from the aquifer solids.

Finally, ${ }^{3} \mathrm{H}-{ }^{3} \mathrm{He}$ apparent ages were not determined for seven ground- and surface-water samples collected from the remaining five wells and one surface-water site. Results of the limited analyses for these samples are listed in table 8 under the heading "Incomplete or fractionated." For one sample collected from well 92-5 and two samples collected from well 92-7, the tritiogenic ${ }^{3} \mathrm{He}$ concentrations, determined with and without a correction for terrigenic helium, were negative. For one sample collected from well $92-7$, the $\left[{ }^{3} \mathrm{H}\right]$ $+\left[{ }^{3} \mathrm{He}_{\text {trit }}\right]$ concentration, determined with and without a correction applied for terrigenic helium, was negative (table 8). The negative concentrations indicate that gas fractionation occurred either during sampling or during extraction and analysis. The four other samples collected listed under the "Incomplete or fractionated" heading have incomplete data. The samples listed are included to provide a record of tritium or helium data collected.

${ }^{3} \mathrm{H}-{ }^{3} \mathrm{He}$ data were evaluated for self-consistency in relation to known ${ }^{3} \mathrm{H}-{ }^{3} \mathrm{He}$ geochemical data. For this purpose, tritium and tritiogenic ${ }^{3} \mathrm{He}$ concentrations and the ${ }^{3} \mathrm{H}-{ }^{3} \mathrm{He}$ apparent ages determined were used to reconstruct the tritium concentration in precipitation for the study area. This reconstruction is compared to the tritium input function for the area, which was determined using longitudinal and latitudinal correlations developed by Michel (1989) for the years 1953-1983. A tritium input of $5 \mathrm{TU}$ was used for the years prior to 1953 based on values from Roether (1967). The $\left[{ }^{3} \mathrm{H}\right]+$ $\left[{ }^{3} \mathrm{He}_{t r i t}\right]$ concentrations and ${ }^{3} \mathrm{H}-{ }^{3} \mathrm{He}$ recharge years in addition to the tritium input function for western Montana are shown in figure 14. The data are consistent with the tritium input function determined by Michel

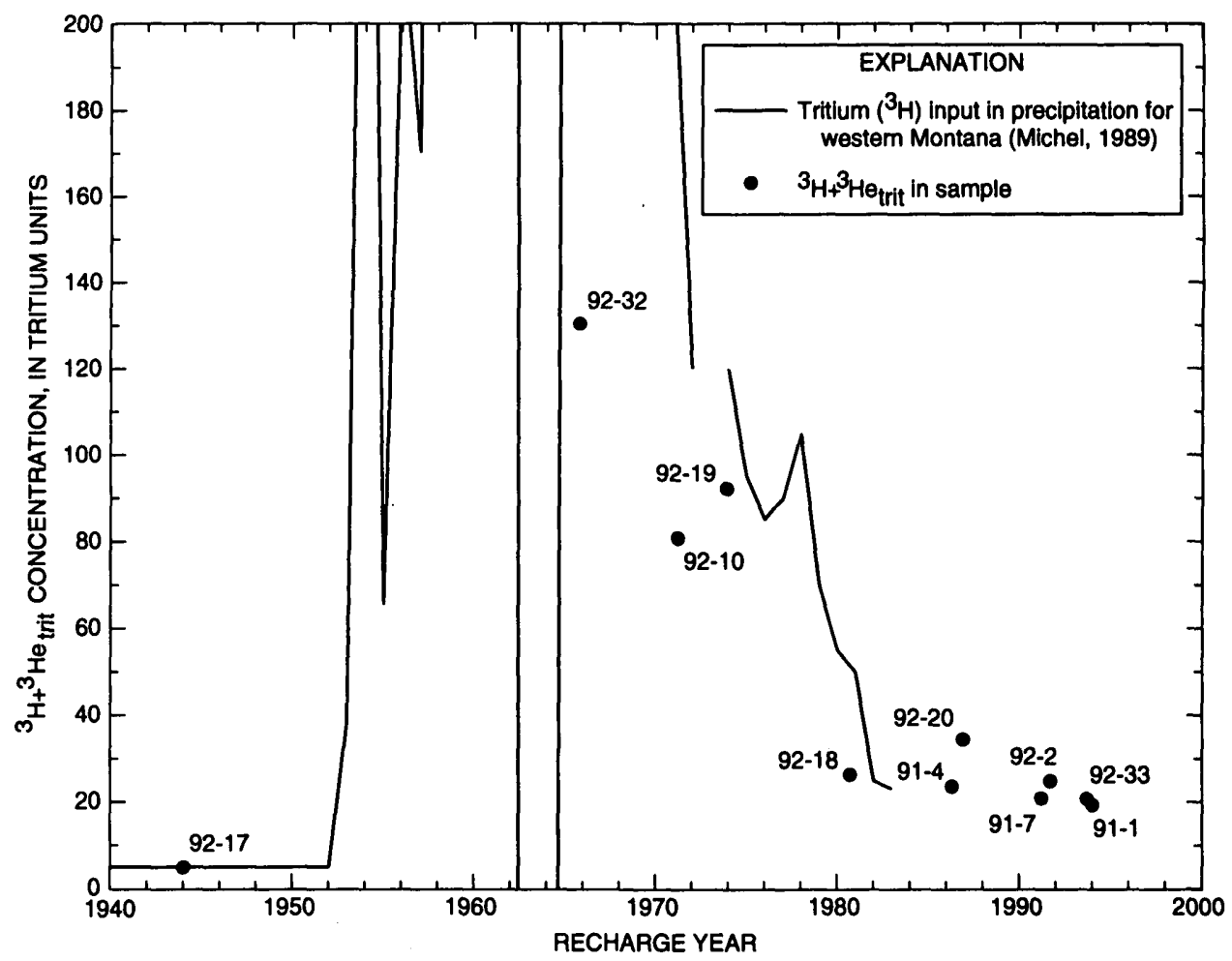

Figure 14. $\left[{ }^{3} \mathrm{H}\right]+\left[{ }^{3} \mathrm{He}_{\text {trit }}\right]$ versus ${ }^{3} \mathrm{H}-{ }^{3} \mathrm{He}$ recharge year. Tritium input for western Montana included for comparison (see text for discussion). 
(1989); however, the maximum $\left[{ }^{3} \mathrm{H}\right]+\left[{ }^{3} \mathrm{He}_{\text {trit }}\right]$ concentration (plotted for 1966) is substantially lower than that expected from the reconstruction of the tritium concentration in precipitation. The smaller concentration could result from hydrodynamic dispersion with a dispersivity of about 4 in. (about $0.1 \mathrm{~m}$ ) or less (Dunkle and others, 1993). The general agreement of the ${ }^{3} \mathrm{H}-{ }^{3} \mathrm{He}$ data with the tritium input function implies that the data are consistent with the known ${ }^{3} \mathrm{H}-{ }^{3} \mathrm{He}$ geochemistry for the study area.

As a result of the sparsity of the ${ }^{3} \mathrm{H}-{ }^{3} \mathrm{He}$ data, the apparent age of water in relation to depth or distance along a flow path could not be determined. The ${ }^{3} \mathrm{H}-{ }^{3} \mathrm{He}$ data are used to help resolve discrepancies in the CFC data discussed in the previous section.

\section{Comparison of Tracer Results}

For many of the ground-water sites sampled in the study area, apparent ages were determined using four different tracers (CFC-11, CFC-12, CFC-113, and ${ }^{3} \mathrm{H}-{ }^{3} \mathrm{He}$ ) (fig. 15). Comparison of the ages determined using these tracers was important in identifying problems and determining how to assign a single recharge age for each site sampled. The apparent ages of each of the four tracers are plotted in relation to the CFC- 12 mean apparent age. Apparent ages within 5 years of the CFC-12 age are noted within the dashed lines in the figure.

The apparent age discrepancies between CFC-11 and CFC-12 discussed earlier in this section can be clearly seen in figure 15 . The differences occur primarily in samples collected near the Beaverhead River or Blacktail Deer Creek. For most of these samples, the ${ }^{3} \mathrm{H}-{ }^{3} \mathrm{He}$ are younger than the CFC- 12 ages. The general consistency between the CFC-12 and CFC-113 ages and the younger ${ }^{3} \mathrm{H}-{ }^{3} \mathrm{He}$ ages determined in these samples was discussed earlier in the section to identify the problem with the CFC-11 apparent ages.

In subsequent discussions of ground-water age, the median CFC-12 apparent age will be used, because CFC-12 ages seem to be the most reliable of the CFC ages determined, and CFC-12 ages are available throughout the study area. The CFC-12 ages will be assumed to represent the apparent ground- and surfacewater age for a site.

\section{Discussion of Tracers in Relation to the Flow System in the Study Area}

Mean apparent ages determined by CFC analysis are shown in figure 16. In general, ground-water ages determined from samples collected at sites along Blacktail Deer Creek indicate a young flow system. Most sites have water less than 10-years old. As discussed in the Water-Quality Analysis section, samples collected from wells in this part of the study area also had different water quality then samples collected from wells in the southwestern part of the study area. The apparent ages of samples collected from these wells and springs indicates that the basin-fill aquifer in this part of the study area probably is affected by local recharge and interactions with Blacktail Deer Creek.

Water collected from wells in the southwestern part of the study area generally is older than water collected from wells along Blacktail Deer Creek. Most of the recharge to the southwestern part of the study area is subsurface recharge from limestone bedrock. This recharge water ranges from 21.3 to 27.3 years of age, as indicated by the age of water collected from the spring (SP1) in Sheep Creek Canyon and wells 92-7 and W38 (fig. 16). In general, ground-water ages along a flow path from spring SP1 to well 92-22 (along section K-K', fig. 16) are older in water collected from the deeper nested wells, which indicates longer travel times. This is especially true in the deeper downgradient nested wells 92-12 (>42.7 years) and 92-13 (9.8 years), and at wells 92-21 (36.5 years) and 92-22 (14.0 years), presumed to intersect a flow system recharged locally by infiltration of precipitation and irrigation. The ages of the water collected from the nested wells 92-10 (21.0) and 92-11 (20.1), however, are similar in spite of the large vertical separation of the open intervals of the wells. No indication of any hydrologic connection between the nested wells as a result of well construction is evident. The water-level head difference between these two wells is about $0.7 \mathrm{ft}$ (table 1 ). The similar ages indicate that vertical mixing of water may be occurring in the area. These wells are located in an area where irrigation provides substantial surface recharge to the aquifer, and in particular, are located near an irrigation well that has a long screened interval that might allow vertical mixing. Water collected from 1 deep well, 92-13 (174 ft in depth) had an age of 9.8 years. 


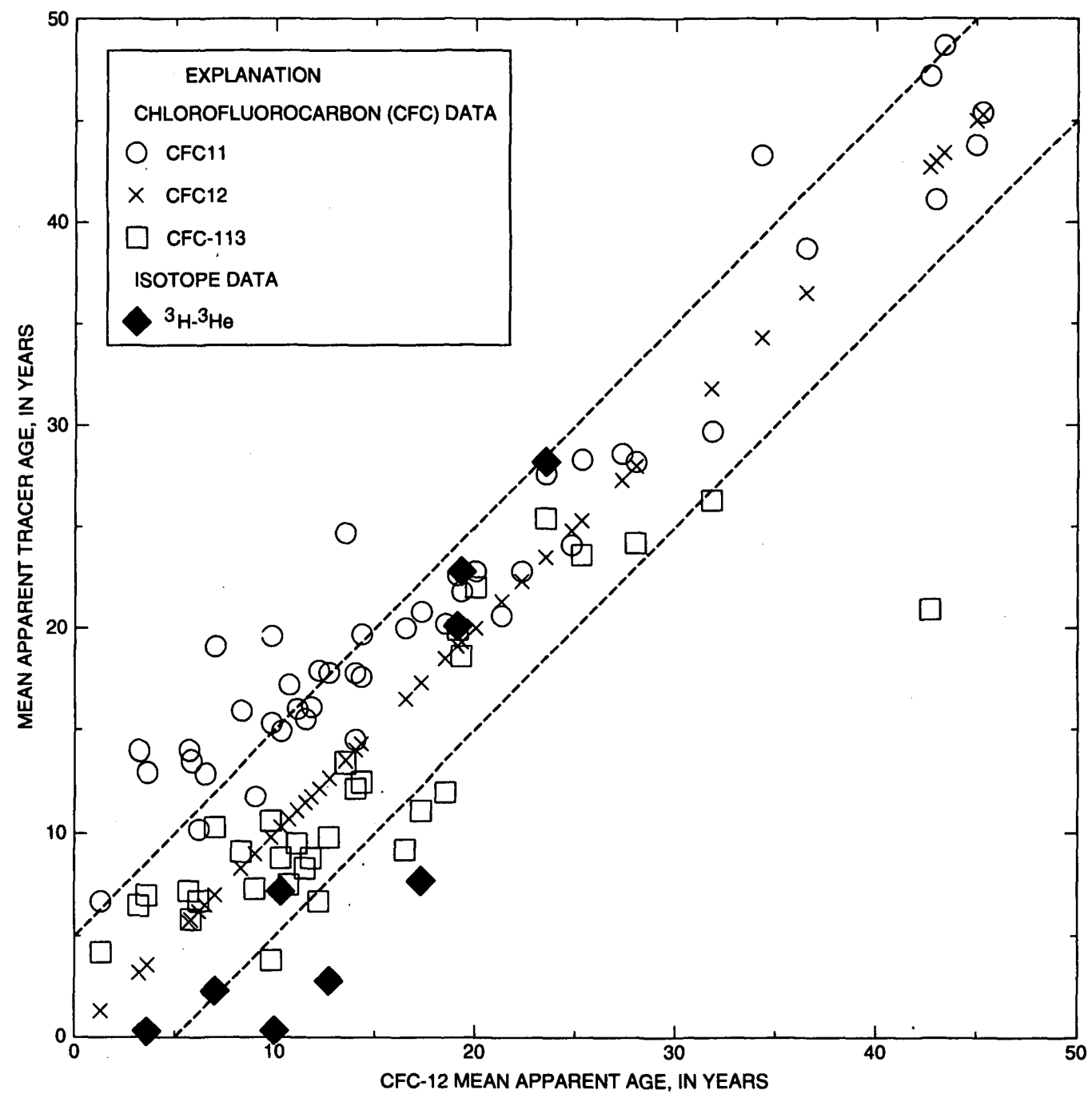

Figure 15. Mean apparent tracer ages compared to the CFC-12 mean apparent age. Points within dashed lines indicate ages within 5-years of the CFC-12 mean apparent age.

Water samples collected from wells located along the Beaverhead River show the effects of both shallow and deep flow systems. The surface-water sample collected at Poindexter Slough (site SW2) was determined to have a CFC-12 age of about 12 years. Care was taken to collect this sample as close to the source of the slough (the area where the ground-water is discharging) as possible. The age is similar to upgradient water collected from shallow wells. Ground water collected from shallow wells (less than about 55 $\mathrm{ft}$ in depth) near the river ranges from 5.7 to 14.3 years, indicating local recharge or a possible interaction with river water. Ground water collected from deeper wells (greater than about $125 \mathrm{ft}$ in depth), however, ranges from about 14.3 to 43.4 years in age which shows the effects of a deep flow system. Wells $92-15,509 \mathrm{ft}$ deep (45.0 years), 92-16, $204 \mathrm{ft} \mathrm{deep.(37.7} \mathrm{years),} \mathrm{and} \mathrm{92-17,}$ $325 \mathrm{ft}$ deep (42.6 years) located in the northern part of the study area produce water that is substantially older than water collected from shallower wells located along either Beaverhead River or Blacktail Deer Creek. An exception to the comparison between deep wells and older water was a sample collected from one well located along the Beaverhead River (well 92-28, $83 \mathrm{ft}$ deep, the deeper well in that particular nest), which was 43.4 years old. 


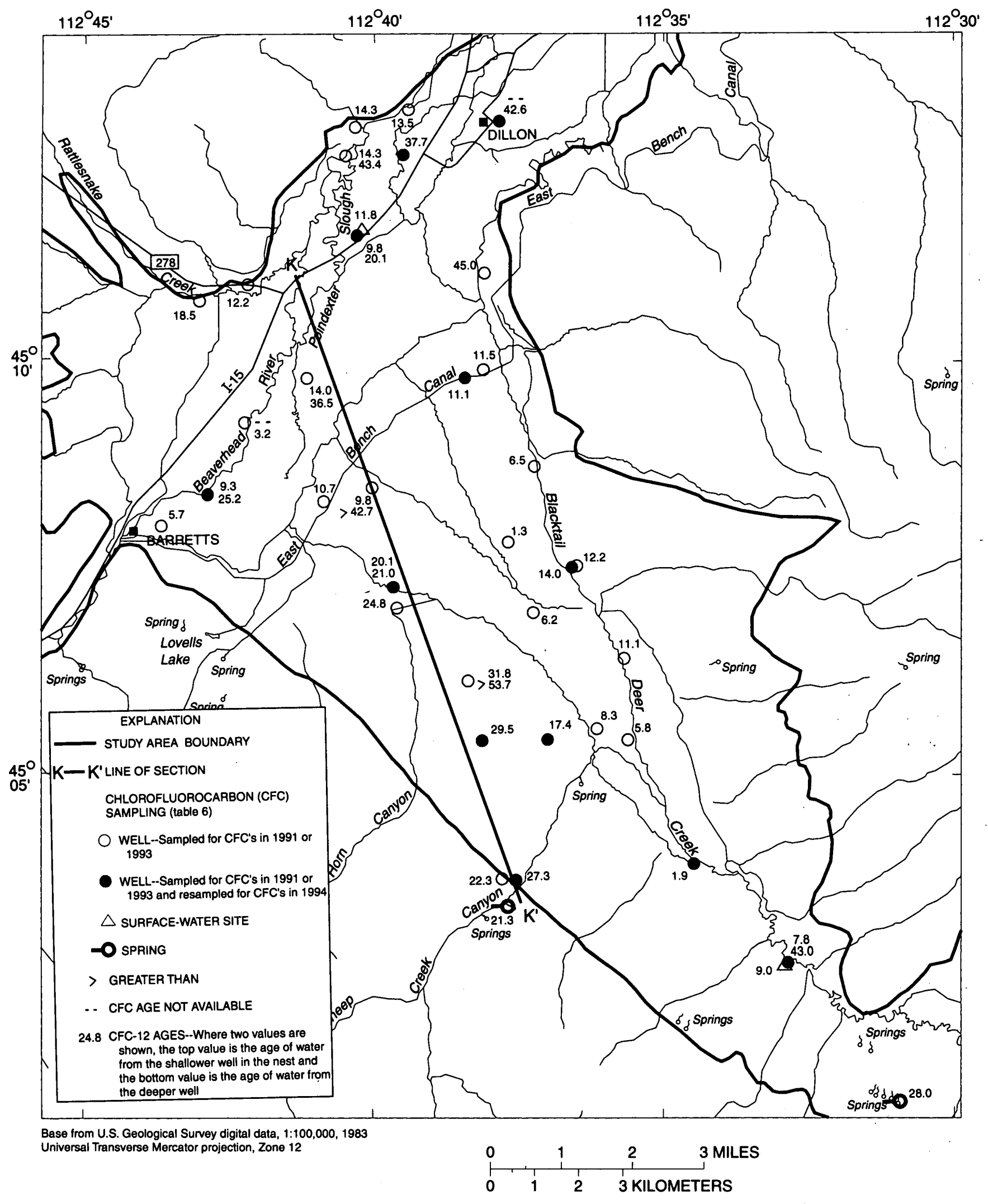

Figure 16. Chlorofluorocarbon (CFC) apparent ages for samples near Dillon, Montana, 1991 and 1993-94. 


\section{FLOW-MODEL ANALYSIS}

A 2-dimensional cross-sectional ground-water flow model was developed to illustrate the key processes affecting ground-water flow in the Blacktail Deer Creek valley and to simulate a typical flow system in the valley. Reasonable model parameters were determined from available data. Ground-water travel times determined by particle tracking, based on the initial numerical simulation, were compared to ground-water ages determined using transient tracers described in the previous section. As a result of the comparison, the conceptual model was refined and tested using a second simulation.

\section{Approach}

The location of the cross section (line of section $\mathrm{K}-\mathrm{K}$ ') used for the simulation was selected based on the potentiometric-surface map (fig. 6) of the basin-fill aquifer, the locations of wells with corresponding driller's logs, water-quality data, and CFC age determinations. The conceptual cross-section simulated is shown in figure 17 . The cross section selected roughly corresponds to a flow line where water flows from a recharge area near Sheep Creek Canyon toward a discharge area at the Beaverhead River or the Poindexter Slough (fig. 17).

Data from wells located along the flow path were used as input for a cross-sectional simulation using the USGS ground-water flow model MODFLOW developed by McDonald and Harbaugh (1988). The potentiometric surface for September 16, 1993, the wells used to measure the water levels, and the length of the perforated or open intervals are shown in figure 17. Path lines and travel times along the flow path were computed using the particle tracking program MODPATH developed by the USGS (Pollock, 1989, 1990, 1994), based on the results of the MODFLOW simulations.

The flow model represents the hydrogeologic framework and hydraulic characteristics of the flow system, and reasonably represents the major processes affecting flow in the valley. The results of two simulations are presented to show (1) the basic flow system, and (2) the effects of withdrawals for irrigation, with increased recharge due to irrigation return flow. Recharge was identified as a major component of the conceptual model based on comparisons of travel times determined from numerical simulation and CFC-12 mean apparent ages. The goal of developing this model was not to produce a calibrated flow model to be used for predictive purposes, but rather to illustrate a conceptual model that represents the major processes affecting ground-water flow in the Blacktail Deer Creek valley.

\section{Conceptual Model}

The simulated aquifer is the unconsolidated alluvial deposits of Quaternary age (Qa) and the upper part of the semi-consolidated and consolidated valley-fill deposits of Tertiary age (Tbz) (fig. 3). In general, the aquifer consists of coarse sand and gravel with discontinuous lenses of silt and clay. The aquifer is assumed to be a single unconfined hydrogeologic unit with no intervening confining layers. Near the south end of section $\mathrm{K}-\mathrm{K}^{\prime}$, the upper part of the aquifer is overlain by alluvial-fan deposits (Qf) (fig. 17). The base of the aquifer is defined as the contact with underlying lowpermeability sediments or bedrock. These are simulated as a no-flow boundary because they are much less permeable than the basin-fill aquifer. Well logs defining the base of the aquifer were limited along the flow line, so available data were used to define a smooth surface for the bottom of the aquifer for the flow model. The base of the aquifer was defined by using well logs for wells 92-8 (341 ft to base) and 92-21 (420 ft to base).

The slope of the potentiometric surface is much steeper in upgradient areas (areas underlying alluvialfan deposits) than downgradient (underlying irrigated areas or near the Beaverhead River and Poindexter Slough) (fig. 17). Hydrographs of water levels measured in wells from 1993-95 located along the flow path are shown in figure 18. Hydrographs of water levels measured in nested wells show an upward gradient at wells 92-8 and 92-9 (fig. 18), a downward gradient at wells 92-12 and 92-13, and 92-21 and 92-22, and a small vertical gradient at wells $92-10$ and 92-11 (fig. 18).

Estimates of the hydraulic characteristics of the basin-fill aquifer were obtained from aquifer tests, including slug tests and multi-well aquifer tests; specific-capacity data were collected from well-performance tests conducted in large-capacity wells. The aquifer test data were collected and analyzed by the DNRC (William Uthman, written commun., 1996). 


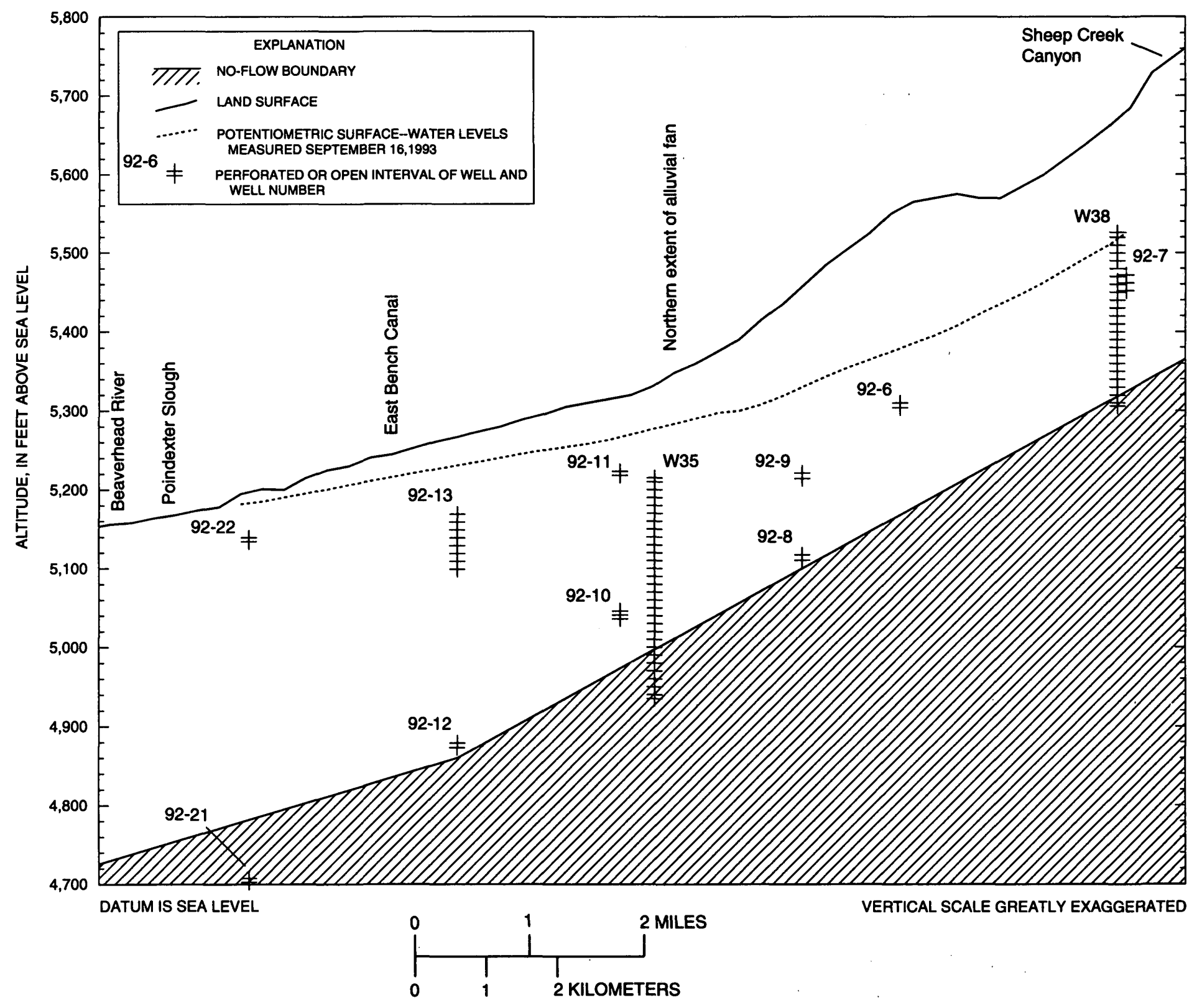

Figure 17. Conceptual cross section along flow path, Blacktail Deer Creek valley, Montana. Line of section (K-K') shown in figure 6.

Hydraulic-conductivity and transmissivity values calculated by the DNRC for different parts of the aquifer along and near the flow path, as well as aquifer thicknesses are listed in table 9. The values are listed, in general, from the recharge area near Sheep Creek Canyon toward the Beaverhead River. The multi-well test data were analyzed by the DNRC as unconfined aquifer tests using the Neuman method (Neuman, 1974) for partially penetrating wells. Slug-test data were analyzed using methods developed by Bouwer and Rice (1976). The specific-capacity data were used at four of the larger diameter wells, with test discharges greater than $1,000 \mathrm{ga} / \mathrm{min}$ and pumping durations of at least 8 hours, to estimate the transmissivity of the aquifer 


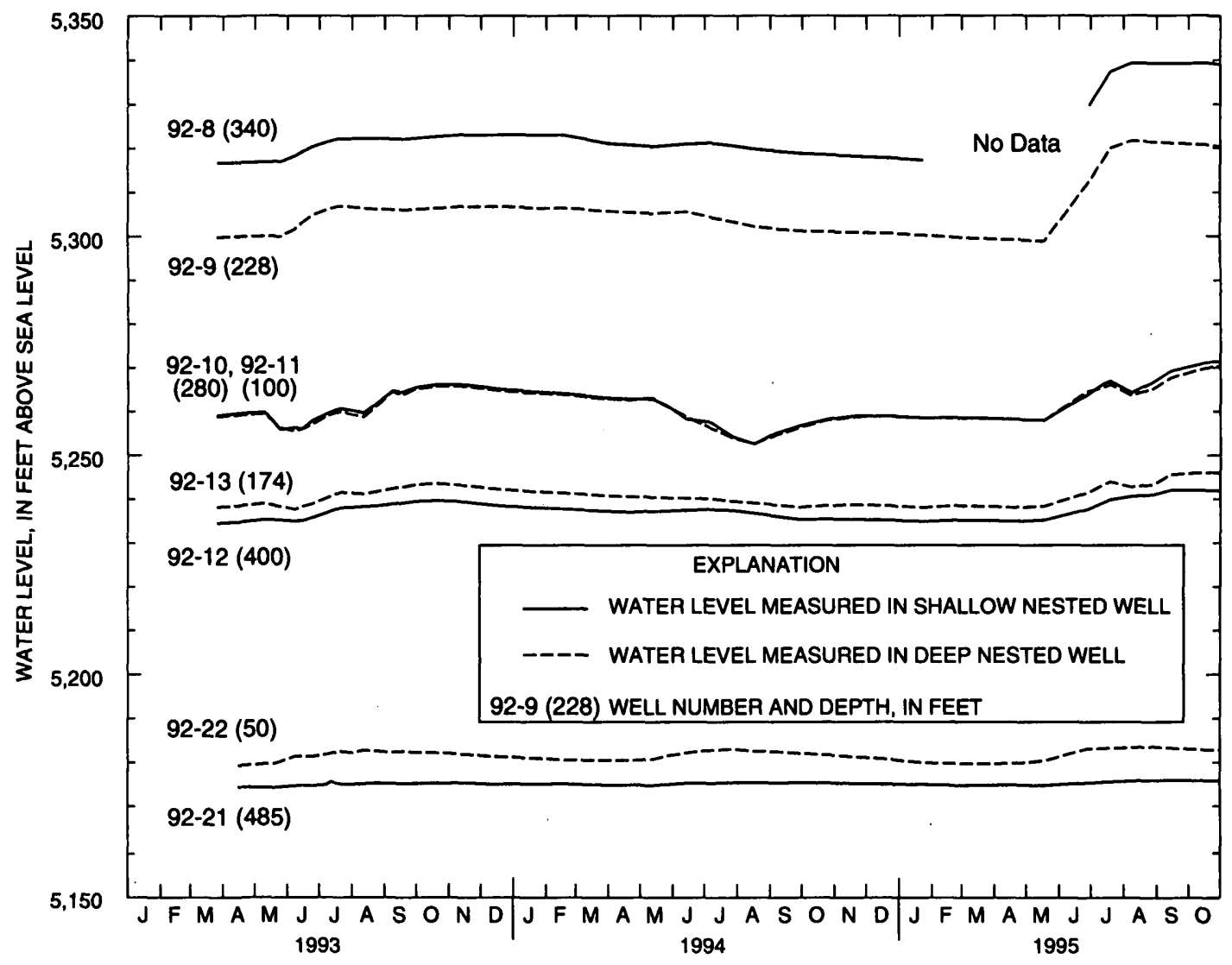

Figure 18. Water levels measured in wells located along the Blacktail Deer Creek valley near Dillon, Montana, from 1993-95.

Table 9. Hydraulic characteristics determined in wells located along line of section K-K' in the lower Blacktail Deer Creek valley, Montana

[Abbreviations: $\mathrm{ft}$, foot; $\mathrm{ft} / \mathrm{d}$, foot per day; $\mathrm{ft}^{2} / \mathrm{d}$, foot squared per day; (gal/min)/ft, gallons per minute per foot. Symbol: --, no data. Data and analysis from the Montana Department of Natural Resources and Conservation]

\begin{tabular}{llcccc}
\hline Well & \multicolumn{1}{c}{$\begin{array}{c}\text { Type of } \\
\text { analysis }\end{array}$} & $\begin{array}{c}\text { Specific } \\
\text { capacity } \\
\text { [(gaV/min)/ft] }\end{array}$ & $\begin{array}{c}\text { Transmissivity } \\
\left(\mathbf{f f t}^{2} / \mathbf{d}\right)\end{array}$ & $\begin{array}{c}\text { Total aquifer } \\
\text { thickness } \\
\text { (ft) }\end{array}$ & $\begin{array}{c}\text { Estimated } \\
\text { hydraulic } \\
\text { conductivity } \\
\text { (ft/d) }\end{array}$ \\
\hline W38 & Multi-well aquifer test & -- & 36,000 & 160 & 225 \\
$92-7$ & Multi-well aquifer test & -- & 128,000 & 160 & 80 \\
W39 & Specific capacity & 50 & 10,400 & 340 & 31 \\
W40 & Specific capacity & 32.7 & 6,500 & 220 & 30 \\
W41 & Specific capacity & 240 & 48,000 & 245 & 200 \\
W30 & Specific capacity & 95 & 18,900 & 300 & 63 \\
$92-13$ & Multi-well aquifer test & - & 85,200 & 170 & 500 \\
$92-24$ & Slug test & -- & 29,500 & 390 & 76 \\
\hline
\end{tabular}


around the wells. Transmissivity values were determined using both the Jacob (Driscoll, 1986) and Theis equations (Heath, 1983) as applied to specificcapacity data. Transmissivity values determined from slug and specific-capacity tests apply only to the screened zone and thus, represent only a small part of the aquifer around the screen. The most representative data available for the aquifer are from the two multi-well tests conducted in wells and 92-7 and 92-13. The multi-well tests provide an estimate of the hydraulic conductivity in a larger area around these wells as a result of the large stress imposed on the system during the tests.

The basin-fill aquifer is recharged by infiltration of precipitation, irrigation recharge, and ground-water inflow from adjacent or underlying bedrock. Recharge due to infiltration of precipitation is estimated to be about $1 \mathrm{in} / \mathrm{yr}$. In areas where the depth to water is large (more than $100 \mathrm{ft}$ ), no recharge is expected to occur.

All precipitation in these areas is expected to be lost to evapotranspiration or used to satisfy soil moisture deficits in the thick unsaturated zone. The aquifer is recharged at the south end of section K-K', near Sheep Creek Canyon, where water issues from spring SP1 at the rate of about 2 to $5 \mathrm{ft}^{3} / \mathrm{s}$ and flows into a small drainage in alluvial-fan deposits. All flow is lost to the basin-fill aquifer or to evapotranspiration as the water flows in the drainage. Because the water flowing over the alluvial-fan deposits is not in contact with the atmosphere very long, this water is assumed to be the same age as the spring water as it recharges the aquifer, which is about 20 years of age.

An assumption is made that the basin-fill aquifer receives a large amount of recharge from the limestone bedrock located near the mouth of Sheep Creek Canyon. Estimates of the amount of recharge from the bedrock were determined using water-level gradients and hydraulic characteristics determined from aquifer tests conducted on wells W38 and 92-7. The aquifer is about $400 \mathrm{ft}$ thick (including unsaturated sediments) at the contact with the limestone bedrock. The gradient between the spring (SP1) near the mouth of Sheep Creek Canyon and well $92-7$ is about $0.1 \mathrm{ft} / \mathrm{ft}$. If the hydraulic conductivity of the limestone ranges from 0.003 to $2 \mathrm{ft} / \mathrm{d}$ (Freeze and Cherry, 1979), then the estimated recharge determined from Darcy's law from a
1 - $\mathrm{ft}$ wide thickness of the bedrock ranges from 0.1 to $80 \mathrm{ft}^{3} / \mathrm{d}$.

The potentiometric-surface map shown in figure 6 indicates that ground-water flows toward the Beaverhead River from both the Blacktail Deer Creek and Rattlesnake Creek valleys. All water in the basin-fill aquifer is assumed to discharge to the Beaverhead River or to the adjacent Poindexter Slough. Low-flow investigations conducted by the DNRC indicate that the Beaverhead River gains about $40 \mathrm{ft}^{3} / \mathrm{s}$ in the area near that modeled, and Poindexter Slough gains about $50-60 \mathrm{ft}^{3} / \mathrm{s}$ from ground-water inflow (William Uthman, written commun., 1996). The slough gains from 8.5 to $11 \mathrm{ft}^{3} / \mathrm{s}$ per river mile.

\section{Numerical Model}

The numerical ground-water flow model MODFLOW (McDonald and Harbaugh, 1988) was used to simulate steady-state ground-water flow along the cross-section. The particle-tracking program MODPATH (Pollock, 1989, 1990, 1994) was used to analyze the results of the simulations and to calculate simulated travel times of water.

\section{Model Grid and Boundary Conditions}

The steady-state numerical ground-water flow model consists of 3 layers and 49 columns of blockcentered grid cells with a uniform grid spacing of 1,000 $\mathrm{ft}$. The model grid is shown in figure 19. The three layers are of variable thickness and are used to allow variations in hydraulic characteristics and rates of recharge from adjacent bedrock units. Layers 1 and 2 represent alluvial deposits of Quaternary age (Qa) (fig. 3), and layer 3 represents deposits of Tertiary age (the upper part of Tbz). No intervening confining units are simulated.

The top of layer 1 was assumed to be $10 \mathrm{ft}$ above the potentiometric surface on September 16, 1993 (fig. 6 ). The bottom of layer 1 (and top of layer 2) was defined by dividing the alluvium (Qa) into two equal parts, such that the thickness of layers 1 and 2 for any column were equal. The bottom of layer 2 is defined as the bottom of the Quaternary (Qa) deposits and the top of Tertiary deposits (Tbz). The bottom of layer 3 is defined as a no-flow boundary. 
Recharge from precipitation and snowmelt is applied at a rate of $1 \mathrm{in} / \mathrm{yr}$ in all cells except those overlain by alluvial fan deposits (columns 30-48). Recharge from the adjacent limestone bedrock at the southern end of the section (K-K') is applied to column 49 near the mouth of Sheep Creek Canyon (fig. 19). The amount of recharge from the bedrock was refined during model development. Bedrock recharge is applied to all three layers at a rate of $25 \mathrm{ft}^{3} / \mathrm{d}$ (for a total recharge of $75 \mathrm{ft}^{3} / \mathrm{d}$ ). Recharge is also applied to the top of column 49 to represent the water issuing from the spring (SP1) that flows across the alluvial-fan deposits in this area. The rate of recharge and the age of the recharged water were determined during model development. The rate of recharge was estimated by taking a fraction of the measured discharge of the spring ( 2 to

NORTH

SOUTH

$\mathrm{K}$

FEET

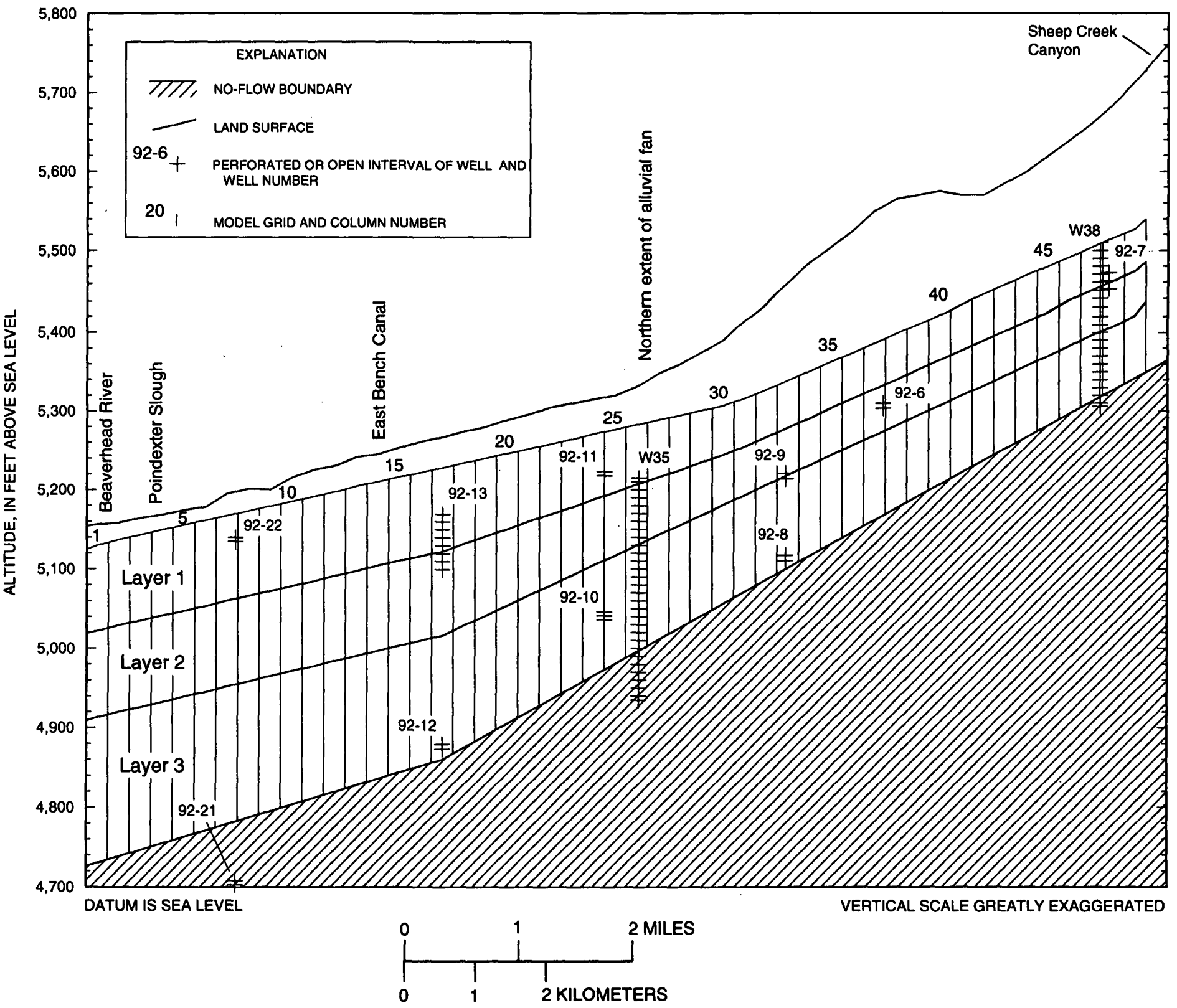

Figure 19. Model grid, layers, and boundary conditions. Line of section shown in figure 6 . 
$5 \mathrm{ft}^{3} / \mathrm{s}$ ) that recharges the simulated flow path and was refined during calibration. Although all flow issuing from the spring recharges the basin-fill aquifer, only a portion of that flow is simulated in the cross section. During model development, the rate of recharge from the spring was determined to be $0.0007 \mathrm{ft}^{3} / \mathrm{s}$.

Discharge to the Beaverhead River and Poindexter Slough were simulated using the river package in MODFLOW (McDonald and Harbaugh, 1988). The river boundary and the slough were placed in layer 1 , and streambed conductances were estimated from aquifer hydraulic characteristics.

\section{Hydraulic Characteristics}

Horizontal hydraulic-conductivity values used in the model range from 40 to $125 \mathrm{ft} / \mathrm{d}$. Most of the variations in the transmissivity values determined are a result of changes in aquifer thickness rather than changes in hydraulic conductivity. Hydraulic-conductivity values assigned to layers 1 and 2 were assumed to be equal due to the similarity of the unconsolidated alluvial deposits (Qa). Hydraulic-conductivity values are less in areas underlying alluvial-fan deposits (Qf) (near the south end of the section) in relation to areas where alluvial-fan deposits are not present (fig. 3). A hydraulic-conductivity value equal to about two-thirds of the value assigned to layers 1 and 2 was assigned to layer 3. Layer 3 consists of semi-consolidated Tertiary deposits ( $\mathrm{Tbz}$ ) that are more indurated than the alluvial deposits. Hydraulic-conductivity values in layers 1 and 2 are $100 \mathrm{ft} / \mathrm{d}$ in columns $1-18,125 \mathrm{ft} / \mathrm{d}$ in columns 1931 , and $65 \mathrm{ft} / \mathrm{d}$ in columns $40-48$. Hydraulic-conductivity values assigned to layer 3 are $66 \mathrm{ft} / \mathrm{d}$ in columns 1 $18,83 \mathrm{ft} / \mathrm{d}$ in columns $19-31$, and $43 \mathrm{ft} / \mathrm{d}$ in columns $32-$ 49. Vertical hydraulic-conductivity values are assumed to be one-tenth the horizontal hydraulic-conductivity values.

\section{Results of Simulation}

The results of the basic simulation described in the "Conceptual Model" section are shown in figure 20. In this simulation, recharge by infiltration of precipitation is applied to layer 1 at the rate of $1 \mathrm{in} / \mathrm{yr}$. Recharge is not applied in the areas overlain by alluvial-fan deposits (columns 30-48). The simulated heads in all three layers are similar and closely match the observed potentiometric surface. Simulated discharge to the Beaverhead River and Poindexter Slough are similar in comparison to data collected by the DNRC during their low-flow investigation. The basic simulation appears to be a reasonable representation of the flow system based on comparisons to available water-level and discharge data.

Particle-tracking analysis was used to estimate travel times of water particles recharging the aquifer to wells that had apparent ages determined from the transient-tracer analysis. Simulated travel times are compared to the apparent ages of the water in these wells (determined from the particle-tracking analysis). Particles were simulated as being input along the perforated or screened intervals of the wells sampled and were tracked backward until the particles reached a recharge boundary. The estimated travel time for particles to each well is defined as the average time needed for particles placed along the perforated or screened interval of the well to reach a recharge boundary. A typical porosity for unconsolidated deposits of 0.3 was used in the particle-tracking analysis.

The CFC data add a new constraint on the flow system that must be met along with the head and discharge data. Estimated travel times of water particles to 11 wells and the mean apparent CFC-12 ages for wells located along the cross section are listed in table 10. In the basic simulation, water flowing to all of the wells originated as recharge from bedrock, so 20 years were added to the calculated travel times before comparison with CFC ages. Estimated travel times shown in bold print in table 10 have been adjusted by adding 20 years to the estimated travel time to account for the age of the recharge water. Although the basic simulation was consistent with head and discharge data, it is not consistent with the apparent ground-water ages.

Travel times of water particles to wells in the upgradient area of the flow system match the CFC-12 mean apparent ages relatively well. However, water from wells in downgradient areas have travel times that are much greater than CFC-12 ages. The conceptual model, as represented in the basic simulation, is incomplete because travel times for the water to flow from the recharge area to the downgradient wells are too great.

Adjustments were made to the conceptual model to better represent the ground-water flow system. The effects of ground-water withdrawals from wells used for irrigation and infiltration of water from irrigated fields were not included in the basic simulation. These effects could account for the younger water determined 
NORTH

FEET

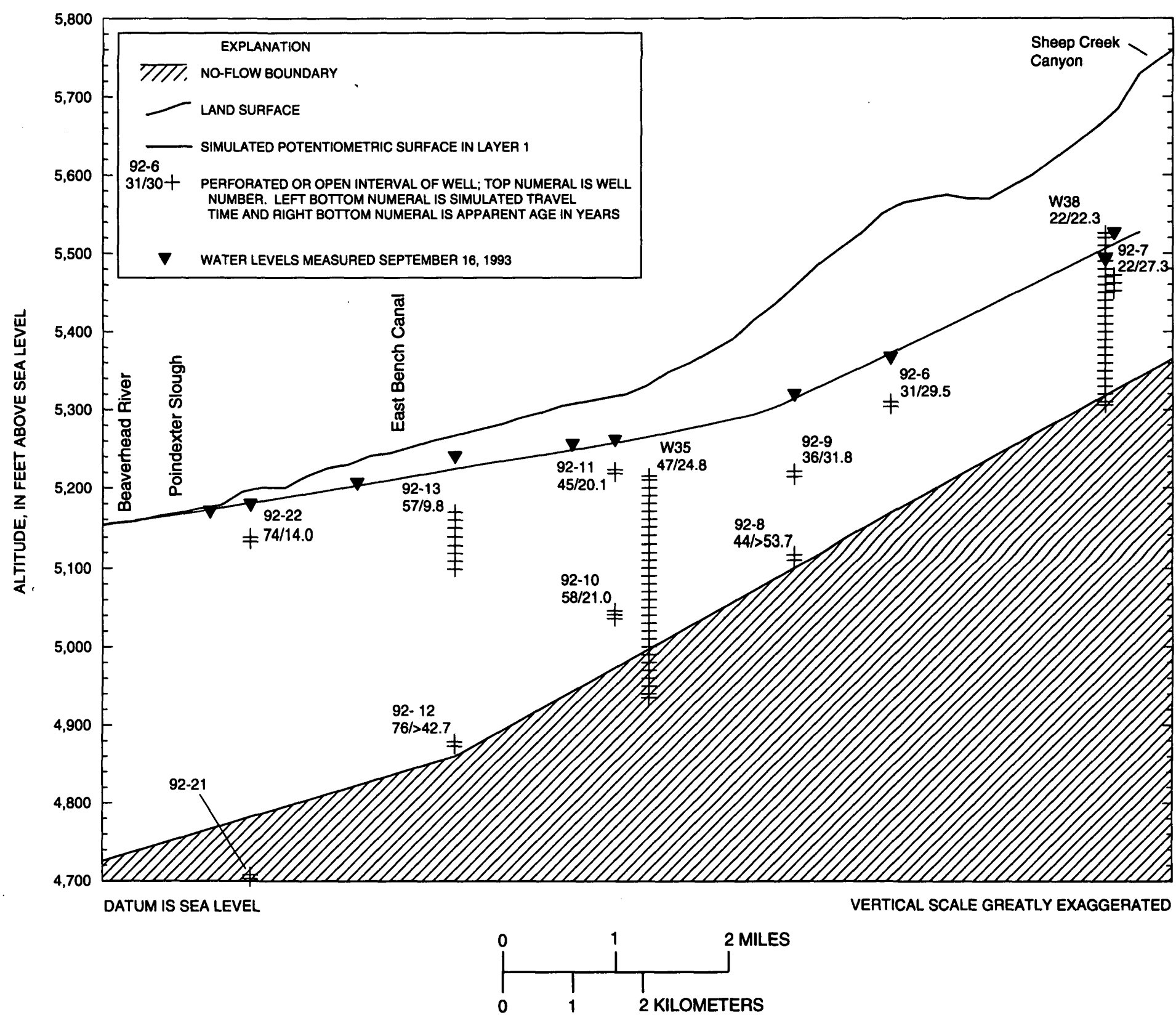

Figure 20. Simulated potentiometric surface and travel times for the basic simulation and CFC-12 mean apparent ages (table 6) and water levels measured September 16, 1993, Blacktail Deer Creek valley, Montana. Line of section (K-K') shown in figure 6. 
Table 10. Comparison of travel times of water particles determined from model simulations and ages determined using the tracer dichlorodifluoromethane (CFC-12) along a flow path (section K-K') in the Blacktail Deer Creek valley, Montana

[Simulated travel times in bold have had 20 years added to simulated travel times to account for the initial age of recharge water. Symbol: >, greater than]

\begin{tabular}{|c|c|c|c|}
\hline \multirow[b]{2}{*}{ Well } & \multicolumn{2}{|c|}{ Simulated travel times, in years } & \multirow{2}{*}{$\begin{array}{c}\text { CFC-12 mean apparent } \\
\text { age, in years }\end{array}$} \\
\hline & Basic simulation & $\begin{array}{l}\text { Irrigation recharge } \\
\text { simulation }\end{array}$ & \\
\hline W38 & 22 & 22 & 22.3 \\
\hline $92-7$ & 22 & 22 & 27.3 \\
\hline $92-6$ & 31 & 30 & 29.5 \\
\hline $92-8$ & 44 & 42 & $>53.7$ \\
\hline $92-9$ & 36 & 34 & 31.8 \\
\hline W35 & 47 & 46 & 24.8 \\
\hline $92-10$ & 58 & $\mathbf{5 5}$ & 21.0 \\
\hline $92-11$ & 45 & 5 & 20 \\
\hline $92-12$ & 76 & 77 & $>42.7$ \\
\hline $92-13$ & 57 & 15 & 9.8 \\
\hline $92-22$ & 74 & 25 & 14.0 \\
\hline
\end{tabular}

by the CFC data in the downgradient areas. Irrigation water would recharge the basin-fill aquifer with water that has equilibrated with the atmosphere and thus provide a source of young water to recharge the aquifer. In addition, ground-water withdrawals used for irrigation might create a downward gradient that would allow younger water to reach the downgradient wells. Ground-water withdrawals for irrigation in the Blacktail Deer Creek valley are from wells located, in general, between the alluvial-fan deposits in the southwestern part of the valley and the East Bench Canal (fig. 3).

A second simulation of the flow system was made to represent the long-term effects of groundwater withdrawals used for irrigation and irrigation recharge. Representation of individual wells was not possible in the 2-dimensional simulation of the system. Thus, withdrawals of water for irrigation are simulated by a uniform withdrawal of water from the top two model layers. Ground-water withdrawals used for irrigation are assumed to be $24 \mathrm{in} / \mathrm{yr}$ on an areal basis for the main irrigated area (columns 15-30) and $6 \mathrm{in} / \mathrm{yr}$ downgradient from the East Bench Canal (William Uthman, oral commun., 1996). Irrigation-induced recharge to the basin-fill aquifer is assumed to be onehalf the withdrawal rate and was applied to layer 1 . The water recharging the aquifer is assumed to have equilibrated with the atmosphere and have modern CFC ages.

Results of the simulation incorporating groundwater withdrawals for irrigation and irrigation recharge are shown in figure 21 . The simulated heads are lower than the measured heads in downgradient areas because of ground-water withdrawals; however, no attempt was made to adjust model parameters or initial recharge rates. Not adjusting the parameters or rates allows simulations of the two conceptual models to be directly comparable.

Estimated travel times for the irrigation-recharge simulation in comparison to CFC-12 mean apparent ages are shown in table 10. Estimated travel times in comparison to the CFC-12 ages show travel times of water to wells in the south part of the section are unchanged from the age estimated from the basic simulation. Estimated travel times in shallow wells in the downgradient areas (92-11, 92-13, 92-22) match the apparent CFC-12 ages more closely than in the basic simulation. Estimated travel times of water to deeper wells located in the downgradient area (wells W35, 9210, and 92-12) are still older than the CFC-12 apparent ages.

The irrigation-recharge simulation could be refined to better simulate the flow system. Hydraulic characteristics were adjusted during model development of the basic simulation. Adjustments to characteristics could improve the match of simulated and measured heads and travel times to the deeper downgradient wells.

The conceptual model of the ground-water flow system along the section was revised for the irrigationrecharge simulation. Recharge from the limestone bedrock is a large component of the flow system. The basin-fill aquifer is also recharged by the water from spring SP1 as the water flows over the alluvial-fan 
NORTH

FEET

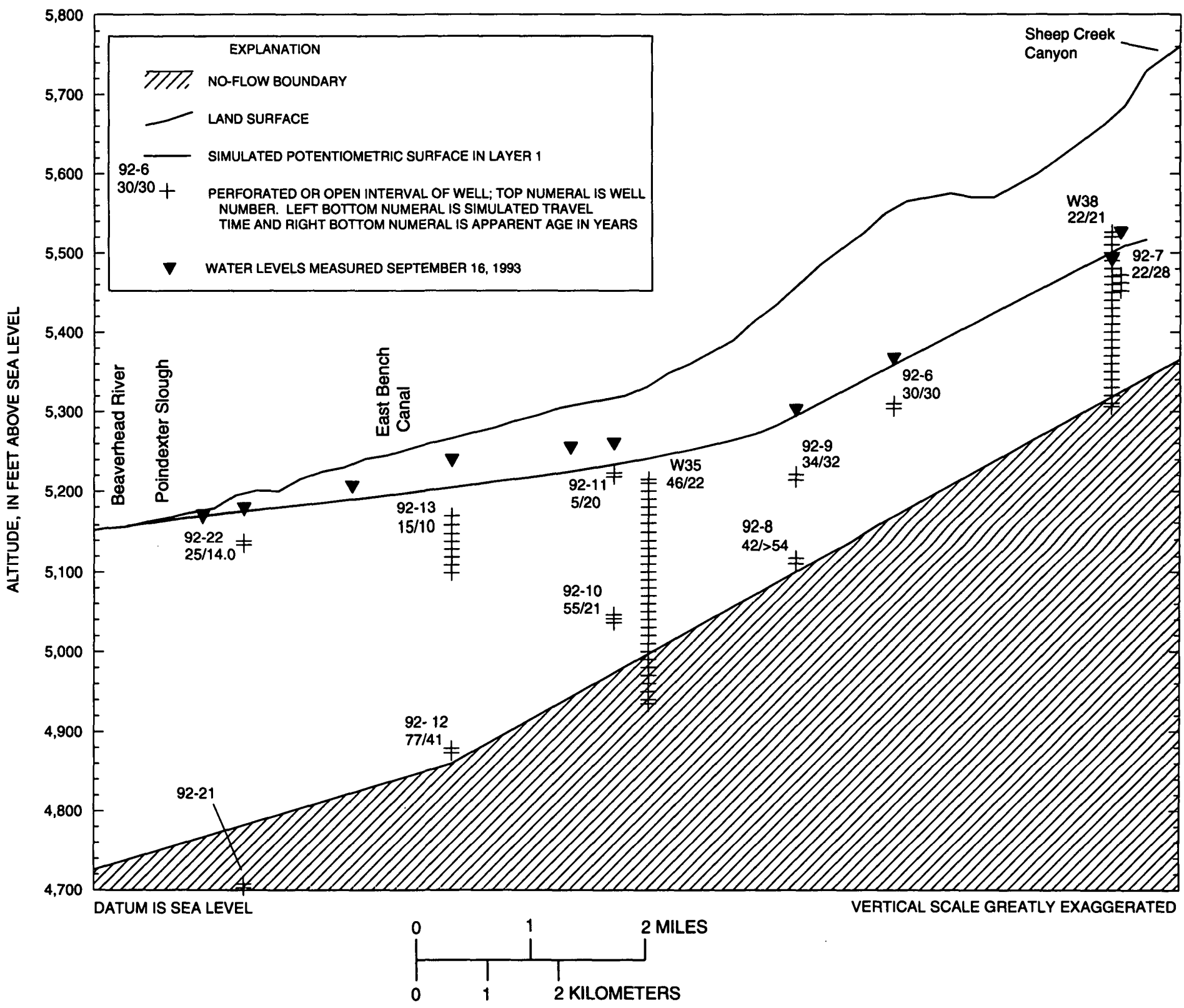

Figure 21. Simulated potentiometric surface and travel times for the simulation, including irrigation withdrawals and irrigation recharge, and CFC-12 mean apparent ages and water levels measured September 16, 1993, Blacktail Deer Creek valley, Montana. Line of section (KK') shown in figure 6. 
deposits near Sheep Creek Canyon. Recharge is not applied to the top of the model in areas where the alluvial-fan deposits overlie alluvium and the unsaturated zone is relatively thick. The flow system in this part of the aquifer is dominated by regional flow or deep flow due to the recharge of the aquifer along the southwestern side of the valley. In the northern part of the section, vertical mixing of the water is occurring as young irrigation recharge enters the top of the aquifer and older water is withdrawn from deeper wells used for irrigation. The mixing creates a shallow flow system, where younger water recharges the aquifer. Water from deep wells along the section in this part of the aquifer is older and reflects the flow system driven by the recharge from the limestone bedrock that occurs near the south end of the section. The Beaverhead River still forms the boundary of the aquifer at the north end of the section, and the assumption is made that all water discharges to the river from both the Blacktail Deer Creek and Rattlesnake Creek valleys.

\section{SUMMARY AND CONCLUSIONS}

In 1993-94, the U.S. Geological Survey, in cooperation with the Montana Department of Natural Resources and Conservation, began a study to describe the ground-water system in a basin-fill aquifer located in the lower Blacktail Deer Creek, lower Beaverhead River, and lower Rattlesnake Creek valleys near Dillon, Montana. The system is described using waterlevel measurements, geophysical data, water-quality data, ground-water ages determined from transient tracers, and a cross-sectional ground-water flow model.

The basin-fill aquifer consists of unconsolidated deposits of Quaternary age and semi-consolidated and consolidated valley-fill deposits of Tertiary age. The aquifer is bounded by various deposits of Tertiary age, sandstone and carbonates of Paleozoic age, and a gneiss of Archean age. The aquifer is at least 485 feet thick near the Beaverhead River between Barretts and Dillon. The base of the aquifer typically is bounded by the lower part of the Bozeman Group or volcanic rocks of Tertiary age, sandstone and carbonates of Paleozoic age, and gneiss of Archean age. The aquifer is recharged by infiltration of precipitation and snowmelt, irrigation recharge, and ground-water inflow from adjacent or underlying bedrock. Water discharges from the aquifer by evapotranspiration, withdrawals from wells, and seepage to the Beaverhead River and adjacent sloughs. Some water flows out of the study area within the aquifer.

Water levels measured in wells located along Blacktail Deer Creek reflect seasonal effects more strongly and had larger annual variations than wells located near the East Bench area in the southwestern part of the study area. Substantial recharge to the ground-water system is apparent during the wet summers of 1993 and 1995.

Seismic-refraction surveys were conducted in 1994 to help define the geometry of the basin-fill aquifer in the study area. Ten profiles constructed from the surveys were used to help define the depth to the Quaternary-Tertiary interface, other lithologic contacts, and depths to the water table and bedrock, when possible. The surveys showed that many of the highly productive areas of the aquifer previously considered to be in Quaternary deposits were in fact in Tertiary deposits. Bedrock--consisting of volcanic rocks of Tertiary age, carbonates of Paleozoic age, or gneiss of Archean age--was identified in four of the profiles.

Water-quality samples were collected from a total of 66 wells, 2 springs, and 5 surface-water sites during 1991-94. Most of the water in the aquifer is a calcium bicarbonate type. Samples collected from spring SP1, which issues from limestone bedrock (possibly a limestone of the Madison Group of Mississippian age), and from two wells located in the same area (92-7 and W38) are a calcium bicarbonate-sulfate water type. Samples from several deep wells located along a flow path from this recharge area to the Beaverhead River also are a calcium bicarbonate-sulfate water type. Water issuing from spring SP2, possibly from a gneiss of Archean age, is a calcium-magnesium bicarbonate type, which was distinct from all other samples collected in the study area.

Concentrations of some trace elements in samples collected along Blacktail Deer Creek were different than concentrations in samples collected in the southwestern and western parts of the study area. Concentrations of lithium and strontium generally were greater in samples collected from the southwestern part of the study area. Concentrations of barium were greater in samples collected along Blacktail Deer Creek and in the northern part of the study area. These relations indicate that sources of ground water in the 
southwestern part of the study area and in the Blacktail Deer Creek area are different and distinct.

Chlorofluorocarbon (CFC) and tritium and helium-isotope $\left({ }^{3} \mathrm{H}-{ }^{3} \mathrm{He}\right)$ dating techniques were used to estimate the apparent ages of water in the basin-fill aquifer. Apparent ground-water ages based on concentrations of three different CFC compounds, trichlorofluoromethane $\left(\mathrm{CCl}_{3} \mathrm{~F}\right.$ or $\left.\mathrm{CFC}-11\right)$, dichlorodifluoromethane $\left(\mathrm{CCl}_{2} \mathrm{~F}_{2}\right.$ or $\left.\mathrm{CFC}-12\right)$, and trichlorotrifluoroethane $\left(\mathrm{C}_{2} \mathrm{Cl}_{3} \mathrm{~F}_{3}\right.$ or $\left.\mathrm{CFC}-113\right)$ were determined at 49 sites. Twenty-one ground-water samples were collected for ${ }^{3} \mathrm{H}-{ }^{3} \mathrm{He}$ analysis. Because $\mathrm{CFC}$ data were available from all of the sites and because ${ }^{3} \mathrm{H}-{ }^{3} \mathrm{He}$ data were sparse, $\mathrm{CFC}$ dating was the primary technique used to determine apparent ground-water ages. CFC12 ages were the most reliable ages determined and were available throughout the study area.

Discrepancies between CFC-11 and CFC-12 apparent ages were detected in parts of the study area. A general consistency between the CFC-12, CFC-113, and ${ }^{3} \mathrm{H}-{ }^{3} \mathrm{He}$ ages (where available) indicates that the CFC-11 concentrations in ground water decreased, producing water with an apparently older age. The CFC-11 may be decreased by biodegradation in anoxic zones created by biogenic activity in the unsaturated zone.

Apparent ground-water ages were estimated using the ${ }^{3} \mathrm{H}-{ }^{3} \mathrm{He}$ dating technique in samples collected at 11 sites. Corrections for terrigenic helium were required in samples collected at eight of the sites. The ${ }^{3} \mathrm{H}-{ }^{3} \mathrm{He}$ ages were consistent with the ${ }^{3} \mathrm{H}-{ }^{3} \mathrm{He}$ geochemistry of the water in the study area and with the estimated CFC ages.

CFC-12 ages of water in samples collected at sites along Blacktail Deer Creek indicate a shallow flow system. Most samples collected at these sites have mean apparent ages less than 10 years of age; exceptions are a few of the deep wells. The apparent ages of water collected from wells and springs indicates that the basin-fill aquifer in this part of the study area probably is affected by local recharge and interactions with Blacktail Deer Creek.

Water collected from wells located in the southwestern part of the study area that is recharged by flow from the limestone bedrock, in general, is much older in comparison to water collected from wells located along Blacktail Deer Creek. Recharge water from spring SP1 located near the mouth of Sheep Creek Can- yon is estimated to be about 20 years old. In general, ground-water ages along a flow path from the spring to well 92-22 are older in water collected from the deeper nested wells. Water from some of the shallow wells located in this area is younger in age, thus indicating that recharge to the aquifer is by infiltration of precipitation or irrigation recharge.

Water samples collected from wells located along the Beaverhead River show the effects of both shallow and deep flow systems. Water collected from shallow wells located near the river, in general, is young in age, indicating local recharge or a possible connection with the river. Ground water collected from deep wells in this area, however, is older, showing the effect of the deep flow system. Water collected from Poindexter Slough, south of the river, was about 12 years old, indicating a local source for the shallow ground water in the area.

Conceptual and numerical cross-sectional ground-water models were developed to illustrate the key processes affecting the ground-water flow system in the study area. The cross section corresponds to a flow line on the potentiometric-surface map constructed for September 16, 1993. The cross section extends from the recharge area near the mouth of Sheep Creek Canyon north toward the discharge area at the Beaverhead River and nearby sloughs. Hydrogeologic data and available well logs were used to estimate the depth of the basin-fill aquifer. Data were obtained from aquifer tests (multi-well pumping tests and slug tests), and specific-capacity determinations conducted in large diameter wells.

A simulation of the conceptual model was developed that represented all key components of the flow system. Travel times determined by water particle tracking, based on flow-model results, were compared to the mean apparent ages of water determined from the CFC-12 dating technique. The basic simulation closely matched measured heads and flows but did not accurately represent the travel times of water in the flow system. The CFC data were used to develop a revised conceptual model that included the effects of irrigation recharge on the aquifer. A simulation of the revised model reasonably matched the heads and flow rates and more accurately matched travel times. 


\section{REFERENCES CITED}

Botz, M.K., 1967, Hydrogeology of the East Bench Irrigation Unit, Madison and Beaverhead Counties, Montana, in Henderson, L.B., ed., Centennial Basin of southwest Montana: Billings; Montana Geological Society, 18th Annual Field Conference Guidebook, p. 79-88.

Bouwer, H., and Rice, R.C., 1976, A slug test for determining hydraulic conductivity of unconfined aquifers with completely or partially penetrating wells: Water Resources Research, v. 12, no. 3, p. 423-428.

Busenberg, Eurybiades, and Plummer, L.N., 1991, Chlorofluorocarbons $\left(\mathrm{CCl}_{3} \mathrm{~F}\right.$ and $\left.\mathrm{CCl}_{2} \mathrm{~F}_{2}\right)--$ Use as an age-dating tool and hydrologic tracer in shallow ground-water systems: U.S. Geological Survey WaterResources Investigations Report 91-4034, p. 542-547.

Busenberg, Eurybiades, and Plummer, L.N., 1992, Use of chlorofluorocarbons $\left(\mathrm{CCl}_{3} \mathrm{~F}\right.$ and $\left.\mathrm{CCl}_{2} \mathrm{~F}_{2}\right)$ as hydrologic tracers and age-dating tools; example--the alluvium and terrace system of central Oklahoma: Water Resources Research, v. 28, no. 9, p. 2257-2283.

Busenberg, Eurybiades, Weeks, E.P., Plummer, L.N., and Bartholomay, R.C., 1993, Age dating ground water by use of chlorofluorocarbons $\left(\mathrm{CCl}_{3} \mathrm{~F}\right.$ and $\left.\mathrm{CCl}_{2} \mathrm{~F}_{2}\right)$, and distributions of chlorofluorocarbons in the unsaturated zone, Snake River Plain Aquifer, Idaho National Engineering Laboratory, Idaho: U.S. Geological Survey Water-Resources Investigations Report 934054, $47 \mathrm{p}$.

Clarke, W.B., Jenkins, W.J., Top, Z., 1976, Determination of tritium by mass spectrometric measurement of ${ }^{3} \mathrm{He}$ :

International Journal Applied Radiation Isotopes, v. 27, p. 515-522.

Cook, P.G., Solomon, D.K., Plummer, L.N., Busenberg, Eurybiades, and Schiff, S.L., 1995, Chloroflurocarbons as tracers of groundwater transport processes in a shallow, silty sand aquifer: Water Resources Research, v. 31, no. 3, p. 425-434.

Cunnold, D.M., Prinn, R.G., Rasmussen, R.A., Simmonds, P.G., Alyea, F.N., Cardelino, C.A., Crawford, A.J., Fraser, P.J., and Rosen, R.D., 1986, Atmospheric lifetime and annual release estimates for $\mathrm{CCl}_{3} \mathrm{~F}$ and $\mathrm{CCl}_{2} \mathrm{~F}_{2}$ from 5 years of ALE data: Journal Geophysical Research, v. 91, no. D10, p. 10797-10817.

Driscoll, F.G., 1986, Groundwater and wells (2d ed.): St. Paul, Minn., Johnson Division, 1089 p.
Dunkle, S.A., Plummer, L.N., Busenberg, Eurybiades, Phillips, P.J., Denver, J.M., Hamilton, P.A., Michel, R.L., and Coplen, T.B., 1993, Chlorofluorocarbons $\left(\mathrm{CCl}_{3} \mathrm{~F}\right.$ and $\left.\mathrm{CCl}_{2} \mathrm{~F}_{2}\right)$ as dating tools and hydrologic tracers in shallow groundwater of the Delmarva Peninsula, Atlantic Coastal Plain, United States: Water Resources Research, v. 29, no. 12, p. 3837-3860.

Egboka, B.C.E., Cherry, J.A., Farvolden, R.N., and Frind, E.O., 1983, Migration of contaminants in groundwater at a landfill--A case study--3. Tritium as an indicator of dispersion and recharge: Journal of Hydrology, v. 63, p. 51-80.

Ekwurzel, B., Schlosser, P., Smethie, W.M., Jr., Plummer, L.N., Busenberg, Eurybiades, Michel, R.L., Weppernig, R., and Stute, M., 1994, Dating of shallow groundwater--Comparison of the transient tracers ${ }^{3} \mathrm{H} /{ }^{3} \mathrm{He}$, chlorofluorocarbons, and ${ }^{85} \mathrm{Kr}$ : Water Resources Research, v. 30, no. 6, p. 1693-1708.

Fields, R.W., and Petkewich, R.M., 1967, Tertiary stratigraphy and geologic history of the upper Jefferson, Ruby, lower Beaverhead, and lower Big Hole River valleys, in Henderson, L.B., ed., Centennial Basin of Southwest Montana: Billings, Montana Geological Society, 18th Annual Field Conference Guidebook, $p$. 71-77.

Freeze, R.A., and Cherry, J.A., 1979, Groundwater: Englewood Cliffs, N.J., Prentice Hall, 604 p.

Haeni, F.P., 1988, Application of seismic-refraction techniques to hydrologic studies: U.S. Geological Survey Techniques of Water-Resources Investigations, book 2, chap. D2, $86 \mathrm{p}$.

Hanneman, D.L., and Wideman, C.J., 1991, Sequence stratigraphy of Cenozoic continental rocks, southwestern Montana: Geological Society of America Bulletin, v. 103, p. 1335-1345.

Heath, R.C., 1983, Basic ground-water hydrology: U.S. Geological Survey Water-Supply Paper 2220, 84 p.

Heaton, T.H.E., 1981, Dissolved gases--Some applications to groundwater research: Transactions of the Geological Society of South Africa, v. 84, p. 91-97.

Heaton, T.H.E., and Vogel, J.C., 1981, "Excess air" in groundwater: Journal of Hydrology, v. 50, p. 201-216.

Katz, B.G., Lee, T.M., Plummer, L.N., and Busenberg, Eurybiades, 1995, Chemical evolutions of groundwater near a sinkhole lake, northern Florida, 1. Flow Patterns, Age of groundwater, and influence of lake water leakage: Water Resources Research, v. 31, no. 6, p. 1549-1564.

Klepper, M.R., 1950, A geologic reconnaissance of parts of Beaverhead and Madison Counties, Montana: U.S. Geological Survey Bulletin 969-C, p. 54-85. 
Knapton, J.R., 1985, Field guidelines for collection, treatment, and analysis of water samples, Montana District: U.S. Geological Survey Open-File Report 85409, 86 p.

Knapton, J.R., and Nimick, D.A., 1991, Quality assurance for water-quality activities of the U.S. Geological Survey in Montana: U.S. Geological Survey Open-File Report 91-216, $41 \mathrm{p}$.

Mamyrin, B.A., and Tolstikhin, I.N., 1984, Helium isotopes in nature: Amsterdam, Elsevier, Developments in Geochemistry, v. 3, 273 p.

McCarthy, R.L., Bower, F.A., and Jesson, J.P., 1977, The fluorocarbonozone theory, I, Productions and release-World production and release of $\mathrm{CCl}_{3} \mathrm{~F}$ and $\mathrm{CCl}_{2} \mathrm{~F}_{2}$ (fluorocarbons 11 and 12) through 1975: Atmospheric Environment, v. 11, p. 491-497.

McDonald, M.G., and Harbaugh, A.W., 1988, A modular three-dimensional finite-difference ground-water flow model: U.S. Geological Survey Techniques of WaterResources Investigations, book 6, chap. Al, $586 \mathrm{p}$.

Michel, R.L., 1989, Tritium deposition in the continental United States, 1953-83: U.S. Geological Survey Water-Resources Investigations Report 89-4072, 46 p.

National Oceanic and Atmospheric Administration, 1992, Monthly normals of temperature, precipitation, and heating and cooling degree days, 1961-90, Montana: Asheville, N.C., Climatography of the United States no. 81, unpaged.

Neuman, S.P., 1974, Effect of partial penetration on flow in unconfined aquifers considering delayed gravity response: Water Resources Research, v.10, no. 2, p. 303-312.

Pollock, D.W.,1989, Documentation of computer programs to compute and display path lines using results from the U.S. Geological Survey modular three-dimensional finite-difference ground-water flow model: U.S. Geological Survey Open-File Report 89-381, 188 p.

Pollock, D.W., 1990, A Graphical Kernel System (GKS) version of computer program MODPATH-PLOT for displaying path lines generated from the U.S. Geological Survey three-dimensional finite-difference ground-water flow model: U.S. Geological Survey Open-File Report 89-622, 49 p.

Pollock, D.W., 1994, User's guide to MODPATH/ MODPATH-PLOT, Version 3--A particle tracking post-processing package for MODFLOW, U.S. Geological Survey modular three-dimensional finitedifference ground-water flow model: U.S. Geological Survey Open-File Report 94-464, 234 p.

Poreda, R.J., Cerling, T.E., and Solomon, D.K., 1988; Tritium and helium isotopes as hydrologic tracers in a shallow unconfined aquifer: Journal of Hydrology, $v$. 103, p. 1-9.
Robertson, W.D., and Cherry, J.A., 1989, Tritium as an indicator of recharge and dispersion in a groundwater system in central Ontario: Water Resources Research, v. 25 , no. 6, p. 1097-1109.

Roether, W., 1967, Estimating the tritium input to ground water from wine samples--Ground water and direct runoff contribution of Central European surface waters: Vienna, Isotopes in Hydrology, EAEA-SM-8317, EAEA, p. 73-91.

Ruppel, E.T., O'Neil, J.M., and Lopez, D.A., 1993, Geologic map of the Dillon $1^{\circ} \times 2^{\circ}$ quadrangle, Idaho and Montana: U.S. Geological Survey Miscellaneous Investigations Map I-1803H, scale 1:250,000.

Schlosser, Peter, Smethie, W.M., Plummer, L.N., Busenberg, Eurybiades, Michel, R.L., Weppernig, R., and Stute, M., 1994, Dating of shallow groundwater-comparison of the transient tracers ${ }^{3} \mathrm{H} /{ }^{3} \mathrm{He}$, chloroflurocarbons and ${ }^{85} \mathrm{Kr}$ : Water Resources Research, v. 30, no. 6, p. 1693-1708.

Schlosser, Peter, Stute, M., Dorr, H., Sonntag, C., and Munnich, K.O., 1988, Tritium $/{ }^{3} \mathrm{He}$ dating of shallow ground water: Earth and Planetary Science Letters, v. 89, p. 352-363.

Schlosser, Peter, Stute, M., Sonntag, C., and Munnich, K.O., 1989, Tritiogenic ${ }^{3} \mathrm{He}$ in shallow ground water: Earth and Planetary Science Letters, v. 94, p. 245-256.

Schultz, T.R., Randall, J.H., Wilson, L.G., and Davis, S.N., 1976, Tracing sewage effluent recharge, Tucson, Arizona: Ground Water, v. 14, p. 463-470.

Shapiro, S.D., 1998, Evaluation of the ${ }^{3} \mathrm{He}-{ }^{3} \mathrm{He}$ dating technique in complex hydrogeologic environments: New York, Columbia University, Ph.D. dissertation, $254 \mathrm{p}$.

Shapiro, S.D., Schlosser, Peter, Smethie, W.M., Jr., and Stute, Martin, 1997, The use of ${ }^{3} \mathrm{H}$ and tritiogenic ${ }^{3} \mathrm{He}$ to determine $\mathrm{CFC}$ degradation and vertical mixing rates in Framvaren Fjord, Norway: Marine Chemistry, v. 59, no. 1-2, p. 141-157.

Solomon, D.K., and Sudicky, E.A., 1991, Tritium and helium-3 isotope ratios for direct estimation of spatial variations in groundwater recharge: Water Resources Research, v. 27, no. 9, p. 2309-2319.

Solomon, D.K., Poreda, R.J., Cook, P.G., and Hunt, A., 1995, Site characterization using the ${ }^{3} \mathrm{H} /{ }^{3} \mathrm{He}$ groundwater ages: Ground Water, v. 33, no. 6, p. 988-996.

Solomon, D.K., Poreda, R.J., Schiff, S.L., and Cherry, J.A., 1992, Tritium and helium-3 as groundwater age tracers in the Borden aquifer: Water Resources Research, v. 28, no. 3, p. 741-755.

Solomon, D.K., Schiff, S.L., Poreda, R.J., and Clarke, W.B., 1993, A validation of the ${ }^{3} \mathrm{H} /{ }^{3} \mathrm{He}$ method for determining groundwater recharge: Water Resources Research, v. 29, no. 9, p. 2951-2962. 
Stiff, H.A. Jr., 1951, The interpretation of chemical water analysis by means of patterns: Journal of Petroleum Technology, v. 3, no. 10, sec. 1, p. 15-16; sec. 2, p. 3.

Szabo, Zoltan, Rice, D.E., Plummer, L.N., Busenberg, Eurybiades, Drenkard, S., 1996, Age dating of shallow groundwater with chlorofluorocarbons, tritium/helium 3 , and flow path analysis, southern New Jersey Coastal Plain: Water Resources Research, v. 32, no. 4, p. 10231038.

Telford, W.M., Geldart, L.P., Sheriff, R.E., and Keys, D.A., 1976, Applied geophysics: New York, Cambridge University Press, 860 p.
Thompson, G.M., and Hayes, J.M., 1979, Trichlorofluoromethane in ground water--A possible tracer and indicator of groundwater age: Water Resources Research, v. 15, no. 3, p. 546-554.

Thompson, G.M., Hayes, J.M., and Davis, S.N., 1974, Fluorocarbon tracers in hydrology: Geophysical Research Letters, v. 1, p. 177-180.

U.S. Bureau of the Census, 1991, 1990 census of population and housing summary tape file 1 , comprehensive report, Dillon. Profile 1, Characteristics of the Population: July 1991, 8 p.

Warner, M.J., and Weiss, R.F., 1985, Solubilities of chlorofluorocarbons 11 and 12 in water and seawater: Deep Sea Research, v. 32, p. 1485-1497. 
DATA 


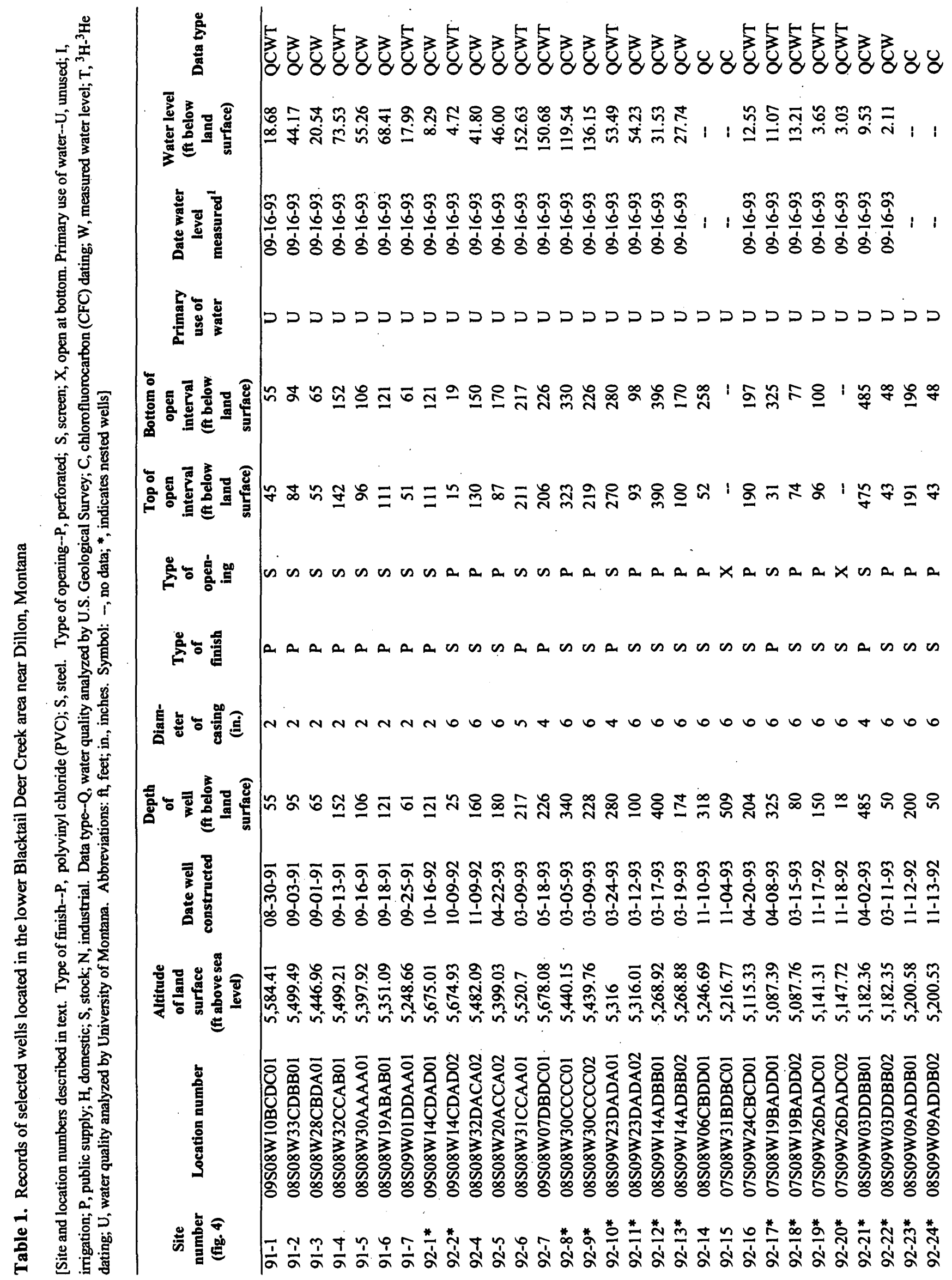




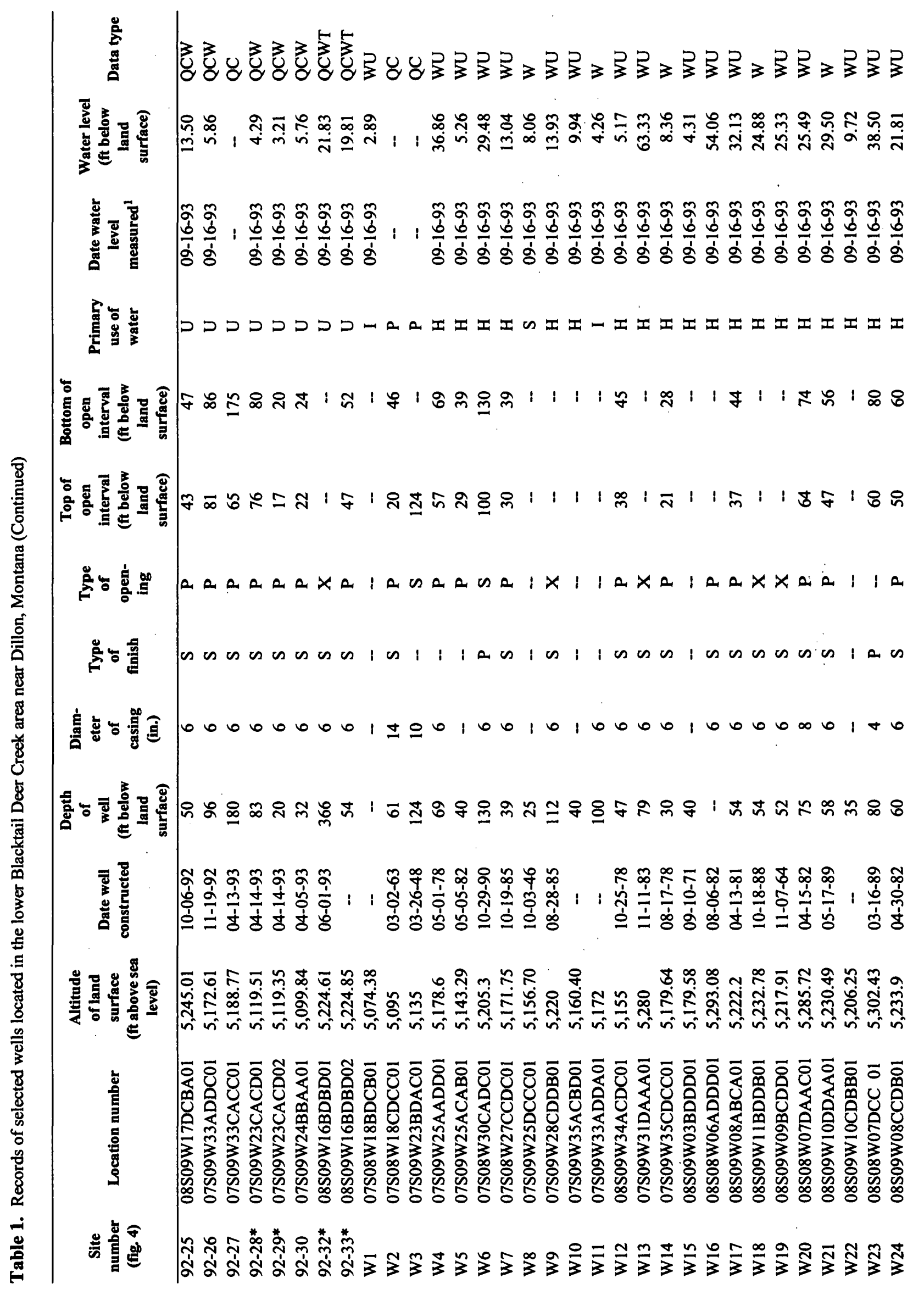

TABLE 151 


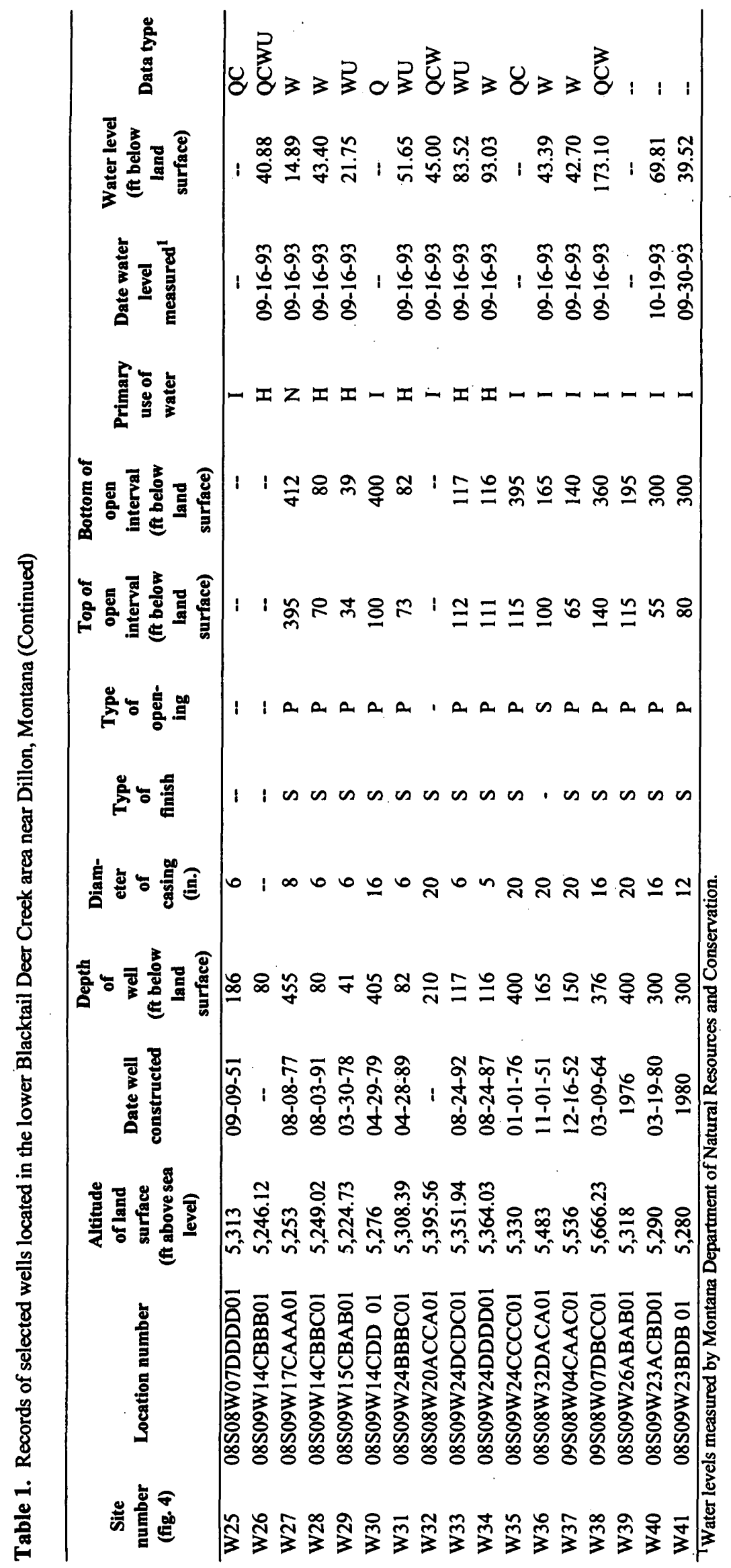


Table 2. Selected springs and surface-water sites sampled in the lower Blacktail Deer Creek area near Dillon, Montana

[Site number described in text. Primary use of water--1, irrigation. Data type--Q, Water-quality analyzed by U.S. Geological Survey; C, chlorofluorocarbon (CFC) dating; U, water quality analyzed by University of Montana. Symbol: --, no data]

\begin{tabular}{|c|c|c|c|c|}
\hline $\begin{array}{c}\text { Site number } \\
\text { (fig. 4) }\end{array}$ & Station name & $\begin{array}{c}\text { Altitude of land } \\
\text { surface } \\
\text { (feet above sea } \\
\text { level) }\end{array}$ & $\begin{array}{c}\text { Primary use of } \\
\text { water }\end{array}$ & $\begin{array}{l}\text { Data } \\
\text { type }\end{array}$ \\
\hline \multicolumn{5}{|c|}{ Springs } \\
\hline SP1 & Spring at Sheep Creek Canyon & 5,730 & I & QC \\
\hline SP2 & Blacktail Spring & 5,990 & - & $Q C$ \\
\hline \multicolumn{5}{|c|}{ Surface-water sites } \\
\hline SW1 & Beaverhead River at Dillon & - & 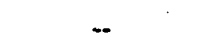 & $\mathbf{U}$ \\
\hline SW2 & Poindexter Slough & - & - & QC \\
\hline sw3 & Blacktail Deer Creek at East Bench Canal & 5,250 & - & $\mathbf{Q}$ \\
\hline SW4 & Beaverhead River at Barretts & $5,268.17$ & - & QU \\
\hline SW5 & Blacktail Deer Creek near Dillon & $5,667.59$ & - & QC \\
\hline
\end{tabular}


Table 4. Physical characteristics, inorganic constituents, and trace elements in ground- and surface-water samples collected by the U.S. Geological Survey in the lower Blacktail Deer Creek area near Dillon, Montana, 1991 and 1993-94

[Site number described in text. Analyses by Montana Bureau of Mines and Geology. Concentration data are dissolved. Abbreviations: $\mu \mathrm{S} / \mathrm{cm}, \mathrm{microsiemens}$ per centimeter at $25^{\circ} \mathrm{C}$; lab, laboratory; ${ }^{\circ} \mathrm{C}$, degrees Celsius; $\mathrm{mg} / \mathrm{L}$, milligrams per liter, IT, incremental titration; FET, fixed endpoint titration; $\mu \mathrm{g} / \mathrm{L}$, micrograms per liter. Symbols: <, less than minimum reporting level; --, no data]

\begin{tabular}{|c|c|c|c|c|c|c|c|c|c|}
\hline $\begin{array}{c}\text { Site } \\
\text { number } \\
\text { (fig. 4) }\end{array}$ & $\begin{array}{c}\text { Date } \\
\text { sampled }\end{array}$ & Time & $\begin{array}{c}\text { Speclfic } \\
\text { conductance, } \\
\text { onsite } \\
(\mu \mathrm{S} / \mathrm{cm}) \\
\end{array}$ & $\begin{array}{c}\text { Specific } \\
\text { conductance, } \\
\text { lab } \\
(\mu \mathrm{S} / \mathrm{cm})\end{array}$ & $\begin{array}{c}\text { pH, } \\
\text { onsite } \\
\text { (standaird. } \\
\text { units) }\end{array}$ & $\begin{array}{c}\text { pH, } \\
\text { lab } \\
\text { (standard } \\
\text { units) }\end{array}$ & $\begin{array}{c}\text { Temperature, } \\
\text { water } \\
\left.\text { ( }^{\circ} \mathrm{C}\right)\end{array}$ & $\begin{array}{l}\text { Oxygen } \\
\text { (mg/L) }\end{array}$ & $\begin{array}{c}\text { Hardness, } \\
\text { total } \\
(\mathrm{mg} / \mathrm{L} \text { as } \\
\left.\mathrm{CaCO}_{3}\right)\end{array}$ \\
\hline $\begin{array}{l}91-1 \\
91-2 \\
91-3 \\
91-4 \\
91-5\end{array}$ & $\begin{array}{l}08-24-93 \\
08-25-93 \\
08-25-93 \\
09-03-93 \\
09-03-93\end{array}$ & $\begin{array}{l}1540 \\
1030 \\
1300 \\
1300 \\
1100\end{array}$ & $\begin{array}{l}547 \\
534 \\
680 \\
547 \\
650\end{array}$ & $\begin{array}{l}510 \\
522 \\
680 \\
534 \\
618\end{array}$ & $\begin{array}{r}\text { Wells } \\
7.4 \\
7.3 \\
7.3 \\
7.5 \\
7.4\end{array}$ & $\begin{array}{l}7.6 \\
7.5 \\
7.3 \\
7.6 \\
7.6\end{array}$ & $\begin{array}{r}8.5 \\
10.5 \\
10.0 \\
11.0 \\
9.0\end{array}$ & $\begin{array}{l}7.4 \\
6.7 \\
7.5 \\
8.4 \\
8.3\end{array}$ & $\begin{array}{l}250 \\
250 \\
320 \\
260 \\
330\end{array}$ \\
\hline $\begin{array}{l}91-6 \\
91-7 \\
92-1 \\
92-2 \\
92-4\end{array}$ & $\begin{array}{l}09-03-93 \\
08-26-93 \\
08-24-93 \\
08-24-93 \\
08-25-93\end{array}$ & $\begin{array}{l}0845 \\
1600 \\
1230 \\
1030 \\
1700\end{array}$ & $\begin{array}{l}547 \\
564 \\
641 \\
566 \\
562\end{array}$ & $\begin{array}{l}526 \\
551 \\
622 \\
543 \\
549\end{array}$ & $\begin{array}{l}7.6 \\
7.6 \\
7.5 \\
7.4 \\
7.4\end{array}$ & $\begin{array}{l}7.7 \\
7.5 \\
7.6 \\
7.5 \\
7.6\end{array}$ & $\begin{array}{r}8.0 \\
9.5 \\
12.0 \\
9.5 \\
10.0\end{array}$ & $\begin{array}{l}8.6 \\
8.2 \\
4.0 \\
1.6 \\
6.5\end{array}$ & $\begin{array}{l}260 \\
270 \\
290 \\
270 \\
270\end{array}$ \\
\hline $\begin{array}{l}92-5 \\
92-6 \\
92-7 \\
92-8 \\
92-9\end{array}$ & $\begin{array}{l}09-15-93 \\
09-01-93 \\
08-31-93 \\
08-31-93 \\
09-01-93\end{array}$ & $\begin{array}{l}1115 \\
1345 \\
1500 \\
1900 \\
1100\end{array}$ & $\begin{array}{l}537 \\
632 \\
647 \\
632 \\
635\end{array}$ & $\begin{array}{l}536 \\
507 \\
629 \\
615 \\
611\end{array}$ & $\begin{array}{l}7.5 \\
7.4 \\
7.4 \\
7.6 \\
7.6 \\
7.4\end{array}$ & $\begin{array}{l}7.6 \\
7.4 \\
7.5 \\
7.6 \\
7.6 \\
7.3\end{array}$ & $\begin{array}{l}10.0 \\
15.0 \\
21.5 \\
14.5 \\
13.5\end{array}$ & $\begin{array}{l}7.8 \\
5.1 \\
2.2 \\
2.8 \\
6.6\end{array}$ & $\begin{array}{l}250 \\
280 \\
310 \\
250 \\
290\end{array}$ \\
\hline $\begin{array}{l}92-10 \\
92-11 \\
92-12 \\
92-13 \\
92-14\end{array}$ & $\begin{array}{l}09-02-93 \\
09-02-93 \\
04-13-94 \\
04-13-94 \\
04-14-94\end{array}$ & $\begin{array}{l}1000 \\
1045 \\
1250 \\
1600 \\
1340\end{array}$ & $\begin{array}{l}582 \\
677 \\
390 \\
640 \\
561\end{array}$ & $\begin{array}{l}560 \\
642 \\
390 \\
623 \\
553\end{array}$ & $\begin{array}{l}7.5 \\
7.5 \\
7.8 \\
7.5 \\
7.2\end{array}$ & $\begin{array}{l}7.4 \\
7.6 \\
7.9 \\
7.6 \\
7.6\end{array}$ & $\begin{array}{r}11.0 \\
11.0 \\
14.0 \\
10.5 \\
8.0\end{array}$ & $\begin{array}{l}7.6 \\
8.1 \\
5.4 \\
6.2 \\
7.3\end{array}$ & $\begin{array}{l}270 \\
310 \\
120 \\
320 \\
280\end{array}$ \\
\hline $\begin{array}{l}92-15 \\
92-16 \\
92-17 \\
92-18 \\
92-19\end{array}$ & $\begin{array}{l}04-14-94 \\
08-27-93 \\
08-23-93 \\
08-23-93 \\
08-26-93\end{array}$ & $\begin{array}{l}1050 \\
1645 \\
1930 \\
1700 \\
1100\end{array}$ & $\begin{array}{l}384 \\
530 \\
504 \\
694 \\
583\end{array}$ & $\begin{array}{l}384 \\
524 \\
499 \\
653 \\
570\end{array}$ & $\begin{array}{l}7.4 \\
7.5 \\
7.8 \\
7.4 \\
7.6\end{array}$ & $\begin{array}{l}7.7 \\
7.5 \\
7.7 \\
6.3 \\
7.6\end{array}$ & $\begin{array}{l}14.0 \\
11.0 \\
12.5 \\
11.5 \\
10.0\end{array}$ & $\begin{array}{l}6.1 \\
4.7 \\
5.4 \\
3.2 \\
5.8\end{array}$ & $\begin{array}{l}160 \\
170 \\
120 \\
330 \\
270\end{array}$ \\
\hline $\begin{array}{l}92-20 \\
92-21 \\
92-22 \\
92-23 \\
92-24\end{array}$ & $\begin{array}{l}08-26-93 \\
09-02-93 \\
09-02-93 \\
08-28-93 \\
08-28-93\end{array}$ & $\begin{array}{l}1230 \\
1530 \\
1450 \\
1130 \\
1245\end{array}$ & $\begin{array}{l}720 \\
478 \\
629 \\
688 \\
770\end{array}$ & $\begin{array}{l}691 \\
479 \\
604 \\
660 \\
731\end{array}$ & $\begin{array}{l}7.5 \\
7.6 \\
7.5 \\
7.4 \\
7.3\end{array}$ & $\begin{array}{l}7.7 \\
7.6 \\
7.7 \\
7.4 \\
7.4\end{array}$ & $\begin{array}{r}9.5 \\
14.5 \\
11.0 \\
9.5 \\
9.5\end{array}$ & $\begin{array}{l}2.7 \\
6.6 \\
7.0 \\
3.1 \\
5.5\end{array}$ & $\begin{array}{l}340 \\
150 \\
300 \\
310 \\
350\end{array}$ \\
\hline $\begin{array}{l}92-25 \\
92-26 \\
92-27 \\
92-28 \\
92-29\end{array}$ & $\begin{array}{l}09-14-93 \\
09-14-93 \\
09-14-93 \\
08-27-93 \\
08-27-93\end{array}$ & $\begin{array}{l}1945 \\
1530 \\
1645 \\
1115 \\
1230\end{array}$ & $\begin{array}{l}645 \\
765 \\
294 \\
505 \\
673\end{array}$ & $\begin{array}{l}633 \\
739 \\
304 \\
503 \\
648\end{array}$ & $\begin{array}{l}7.8 \\
7.6 \\
7.6 \\
7.8 \\
7.4\end{array}$ & $\begin{array}{l}7.7 \\
7.5 \\
7.6 \\
7.7 \\
7.5\end{array}$ & $\begin{array}{r}9.0 \\
10.5 \\
9.0 \\
10.0 \\
10.0\end{array}$ & $\begin{array}{l}5.2 \\
5.5 \\
3.7 \\
3.6 \\
2.7\end{array}$ & $\begin{array}{l}300 \\
350 \\
140 \\
230 \\
310\end{array}$ \\
\hline $\begin{array}{l}92-30 \\
92-32 \\
92-33 \\
\text { W2 } \\
\text { W3 }\end{array}$ & $\begin{array}{l}09-15-93 \\
09-01-93 \\
09-01-93 \\
08-21-91 \\
08-22-91\end{array}$ & $\begin{array}{l}1315 \\
1800 \\
1645 \\
1430 \\
1100\end{array}$ & $\begin{array}{l}719 \\
523 \\
542 \\
719 \\
700\end{array}$ & $\begin{array}{l}702 \\
565 \\
592 \\
711 \\
688\end{array}$ & $\begin{array}{l}7.2 \\
7.7 \\
7.5 \\
7.2 \\
7.3\end{array}$ & $\begin{array}{l}7.6 \\
7.7 \\
7.5 \\
7.6 \\
7.7\end{array}$ & $\begin{array}{r}12.0 \\
10.5 \\
14.0 \\
9.0 \\
9.5\end{array}$ & $\begin{array}{l}.1 \\
2.4 \\
1.6 \\
6.6 \\
2.8\end{array}$ & $\begin{array}{l}330 \\
280 \\
270 \\
340 \\
330\end{array}$ \\
\hline $\begin{array}{l}\text { W25 } \\
\text { W26 } \\
\text { W30 } \\
\text { W32 } \\
\text { W35 }\end{array}$ & $\begin{array}{l}08-21-91 \\
09-15-93 \\
08-21-91 \\
08-20-91 \\
08-21-91\end{array}$ & $\begin{array}{l}1800 \\
1000 \\
1245 \\
1730 \\
1030\end{array}$ & $\begin{array}{l}517 \\
649 \\
670 \\
519 \\
614\end{array}$ & $\begin{array}{l}514 \\
639 \\
664 \\
519 \\
609\end{array}$ & $\begin{array}{l}7.5 \\
7.5 \\
7.9 \\
7.5 \\
7.4\end{array}$ & $\begin{array}{l}7.8 \\
7.8 \\
8.0 \\
7.8 \\
7.7\end{array}$ & $\begin{array}{r}8.5 \\
11.5 \\
10.0 \\
9.5 \\
12.5\end{array}$ & $\begin{array}{c}10.8 \\
7.0 \\
-\overline{9} \\
7.5 \\
7.3\end{array}$ & $\begin{array}{l}250 \\
300 \\
300 \\
240 \\
270\end{array}$ \\
\hline W38 & $08-20-91$ & 1300 & 640 & 644 & 7.4 & 7.7 & 22.0 & 4.8 & 290 \\
\hline $\begin{array}{l}\text { SP1 } \\
\text { SP2 }\end{array}$ & $\begin{array}{l}08-20-91 \\
09-16-93\end{array}$ & $\begin{array}{l}1500 \\
1015\end{array}$ & $\begin{array}{l}660 \\
274\end{array}$ & $\begin{array}{l}659 \\
294\end{array}$ & $\begin{array}{r}\text { Springs } \\
7.4 \\
7.8\end{array}$ & $\begin{array}{l}7.8 \\
7.9\end{array}$ & $\begin{array}{r}20.5 \\
6.5\end{array}$ & $\begin{array}{l}3.9 \\
6.8\end{array}$ & $\begin{array}{l}290 \\
140\end{array}$ \\
\hline $\begin{array}{l}\text { SW2 } \\
\text { SW3 } \\
\text { SW4 } \\
\text { SW5 } \\
\end{array}$ & $\begin{array}{l}08-26-93 \\
08-25-93 \\
05-04-94 \\
08-24-93 \\
\end{array}$ & $\begin{array}{l}1345 \\
1830 \\
1950 \\
1300 \\
\end{array}$ & $\begin{array}{l}900 \\
503 \\
545 \\
517 \\
\end{array}$ & $\begin{array}{l}853 \\
494 \\
499 \\
503 \\
\end{array}$ & $\begin{array}{c}\text { ace-water sites } \\
7.9 \\
8.8 \\
8.5 \\
8.5 \\
\end{array}$ & $\begin{array}{l}7.9 \\
8.4 \\
8.3 \\
8.3 \\
\end{array}$ & $\begin{array}{l}13.0 \\
14.5 \\
11.0 \\
13.0 \\
\end{array}$ & $\begin{array}{r}10.5 \\
8.6 \\
9.2 \\
9.4 \\
\end{array}$ & $\begin{array}{l}440 \\
240 \\
250 \\
250 \\
\end{array}$ \\
\hline
\end{tabular}


Table 4. Physical characteristics, inorganic constituents, and trace elements in ground- and surface-water samples collected by the U.S. Geological Survey in the lower Blacktail Deer Creek area near Dillon, Montana, 1991 and $1993-94$ (Continued)

\begin{tabular}{|c|c|c|c|c|c|c|c|c|c|}
\hline $\begin{array}{c}\text { Site } \\
\text { number } \\
\text { (fig. 4) }\end{array}$ & $\underset{\text { (mg/L) }}{\text { Calcium }}$ & $\begin{array}{c}\text { Magnealum } \\
(\mathrm{mg} / \mathrm{L})\end{array}$ & $\begin{array}{l}\text { Sodlum } \\
\text { (mg/L) }\end{array}$ & $\begin{array}{c}\text { Potassium } \\
\text { (mg/L) }\end{array}$ & $\begin{array}{c}\text { Bicarbonate, } \\
\text { (IT) } \\
\text { onsite } \\
\text { (mg/l as } \\
\mathrm{HCO}_{3} \text { ) } \\
\end{array}$ & $\begin{array}{c}\text { Blearbonate, } \\
\text { (FET) } \\
\text { Iab } \\
\text { (mgle as } \\
\text { HCO }_{3} \text { ) } \\
\end{array}$ & $\begin{array}{c}\text { Carbonate, } \\
\text { (IT) } \\
\text { onsilte } \\
\text { (mg/l as } \\
\left.\mathrm{CO}_{3}\right) \\
\end{array}$ & $\begin{array}{c}\text { Carbonate, } \\
\text { (FET) } \\
\text { lab } \\
\left(\mathrm{mgl}_{2} \mathrm{as}\right. \\
\left.\mathrm{CO}_{3}\right) \\
\end{array}$ & $\begin{array}{c}\text { Alkalinity, } \\
\text { (FET) } \\
\text { onsite } \\
(\mathrm{mg} / \mathrm{L} \text { as } \\
\mathrm{CaCO}_{3} \\
\end{array}$ \\
\hline \multicolumn{10}{|c|}{ Wells } \\
\hline $91-1$ & 67 & 20 & 11 & 4.5 & 262 & 245 & 0 & 0 & 214 \\
\hline $91-2$ & 68 & 19 & 9.3 & 4.4 & 267 & 243 & 0 & 0 & 217 \\
\hline $91-3$ & 87 & 26 & 20 & 4.9 & 312 & 314 & 0 & 0 & 253 \\
\hline $91-4$ & 71 & 20 & 15 & 3.4 & 266 & 273 & 0 & - & 215 \\
\hline $91-5$ & 90 & 25 & 11 & 4.5 & 287 & 291 & 0 & 0 & 231 \\
\hline $91-6$ & 70 & 22 & 11 & 4.0 & 263 & 261 & 0 & - & 212 \\
\hline 91-7 & 72 & 21 & 12 & 5.0 & 272 & 271 & 0 & 0 & 219 \\
\hline $92-1$ & 76 & 24 & 18 & 9.1 & 313 & 318 & 0 & 0 & 255 \\
\hline $92-2$ & 75 & 21 & 12 & 4.3 & 271 & 277 & 0 & 0 & 222 \\
\hline $92-4$ & 75 & 20 & 11 & 4.2 & 274 & 280 & 0 & 0 & 222 \\
\hline $92-5$ & 64 & 22 & 15 & 6.1 & 252 & 259 & 0 & - & 205 \\
\hline $92-6$ & 77 & 22 & 26 & 5.0 & 222 & 231 & 0 & - & 180 \\
\hline $92-7$ & 87 & 23 & 23 & 4.4 & 217 & 236 & 0 & 0 & 176 \\
\hline $92-8$ & 65 & 21 & 37 & 5.7 & 205 & 207 & 0 & 0. & 166 \\
\hline $92-9$ & 78 & 22 & 26 & 5.9 & 227 & 234 & 0 & 0 & 182 \\
\hline $92-10$ & 71 & 22 & 21 & 4.3 & 256 & 262 & 0 & - & 207 \\
\hline $92-11$ & 84 & 25 & 26 & 4.5 & 251 & 256 & 0 & - & 202 \\
\hline $92-12$ & 32 & 8.3 & 34 & 10 & 168 & 174 & 0 & 0 & 138 \\
\hline $92-13$ & 85 & 27 & 14 & 4.2 & 296 & 304 & 0 & 0 & 240 \\
\hline $92-14$ & 74 & 23 & 12 & 5.0 & 267 & 278 & 0 & 0 & 217 \\
\hline $92-15$ & 47 & 9.4 & 15 & 10 & 189 & 195 & 0 & 0 & 155 \\
\hline $92-16$ & 50 & 12 & 40 & 8.2 & 215 & 220 & 0 & 0 & 177 \\
\hline $92-17$ & 38 & 5.5 & 55 & 13 & 228 & 230 & 0 & 0 & 186 \\
\hline $92-18$ & 88 & 26 & 19 & 6.6 & 300 & 307 & 0 & 0 & 245 \\
\hline $92-19$ & 73 & 22 & 15 & 5.1 & 267 & 272 & 0 & 0 & 218 \\
\hline $92-20$ & 90 & 27 & 21 & 5.8 & 303 & 308 & 0 & 0 & 247 \\
\hline $92-21$ & 44 & 9.6 & 37 & 12 & 186 & 174 & 0 & - & 147 \\
\hline $92-22$ & 79 & 24 & 17 & 4.3 & 272 & 276 & 0 & - & 221 \\
\hline $92-23$ & 83 & 25 & 26 & 4.2 & 257 & 267 & 0 & 0 & 208 \\
\hline $92-24$ & 94 & 28 & 30 & 4.9 & 296 & 286 & 0 & 0 & 238 \\
\hline $92-25$ & 79 & 25 & 25 & 3.8 & 230 & 266 & 0 & 0 & 186 \\
\hline $92-26$ & 100 & 22 & 29 & 4.2 & 303 & 304 & 0 & 0 & 243 \\
\hline $92-27$ & 43 & 8.8 & 4.1 & 1.3 & 144 & 154 & 0 & - & 119 \\
\hline $92-28$ & 65 & 16 & 13 & 4.3 & 199 & 210 & 0 & 0 & 163 \\
\hline $92-29$ & 88 & 22 & 22 & 4.3 & 281 & 290 & 0 & 0 & 227 \\
\hline $92-30$ & 86 & 28 & 23 & 5.5 & 326 & 321 & 0 & - & 264 \\
\hline $92-32$ & 74 & 23 & 16 & 3.2 & 236 & 238 & 0 & - & 191 \\
\hline $92-33$ & 69 & 25 & 26 & 4.5 & 254 & 256 & 0 & - & 207 \\
\hline W2 & 92 & 27 & 23 & 5.7 & .- & - & - & - & -. \\
\hline W3 & 89 & 26 & 21 & 5.2 & - & - & - & - & - \\
\hline W25 & 66 & 20 & 12 & 5.2 & 246 & - & 0 & - & 201 \\
\hline W26 & 78 & 25 & 23 & 4.7 & 247 & 254 & 0 & 0 & 200 \\
\hline W30 & 80 & 23 & 22 & 5.4 & 249 & - & 0 & - & 201 \\
\hline W32 & 61 & 22 & 14 & 5.0 & 258 & - & 0 & - & 211 \\
\hline W35 & 72 & 21 & 25 & 4.7 & - & - & - & - & - \\
\hline W38 & 81 & 21 & 24 & 4.4 & 212 & - & 0 & - & 172 \\
\hline \multicolumn{10}{|c|}{ Springs } \\
\hline SPI & 84 & 20 & 25 & 4.5 & 230 & - & 0 & - & 187 \\
\hline \multirow[t]{2}{*}{ SP2 } & 30 & 16 & 4.3 & 2.2 & 170 & 169 & 0 & 0 & 138 \\
\hline & \multicolumn{9}{|c|}{ Surface-water sites } \\
\hline SW2 & 110 & 38 & 29 & 7.9 & 440 & 440 & 0 & 0 & 359 \\
\hline SW3 & 65 & 19 & 9.2 & 4.0 & 230 & 220 & 11 & 7 & 207 \\
\hline SW4 & 64 & 22 & 23 & 4.2 & 231 & 239 & 0 & 0 & 187 \\
\hline sW5 & 69 & 20 & 9.4 & 3.7 & 243 & 263 & 7 & 0 & 210 \\
\hline
\end{tabular}


Table 4. Physical characteristics, inorganic constituents, and trace elements in ground- and surface-water samples collected by the U.S. Geological Survey in the lower Blacktail Deer Creek area near Dillon, Montana, 1991 and 1993-94 (Continued)

\begin{tabular}{|c|c|c|c|c|c|c|c|c|c|}
\hline $\begin{array}{c}\text { Site } \\
\text { number } \\
\text { (fig. 4) }\end{array}$ & $\begin{array}{c}\text { Alkalinity, } \\
\text { (IT) } \\
\text { onsite } \\
\text { (mg/L as } \\
\left.\mathrm{CaCO}_{3}\right) \\
\end{array}$ & $\begin{array}{c}\text { Sulfate, } \\
\text { dissolved } \\
(\mathbf{m g} / \mathbf{L})\end{array}$ & $\begin{array}{c}\text { Chlo- } \\
\text { ride } \\
\text { (mg/L) }\end{array}$ & $\begin{array}{c}\text { Fluo- } \\
\text { ride } \\
\text { (mg/L) }\end{array}$ & $\begin{array}{c}\text { Silica } \\
(\mathrm{mg} / \mathrm{L} \text { as } \\
\left.\text { SiO }_{2}\right)\end{array}$ & $\begin{array}{c}\text { Solids, sum of } \\
\text { constituents } \\
\text { (mg/L) } \\
\text { as } \mathrm{SIO}_{2}\end{array}$ & $\begin{array}{l}\text { Nitrogen, } \\
\text { nitrite, total } \\
(\mathrm{mg} / \mathrm{L} \text { as } \mathrm{N})\end{array}$ & $\begin{array}{l}\text { Nitrogen, } \\
\text { nitrate } \\
\text { (mg/L as N) }\end{array}$ & $\begin{array}{l}\text { Phosphorus } \\
\text { (mg/L as P) }\end{array}$ \\
\hline & & & & & Wells & & & & \\
\hline $91-1$ & 215 & 60 & 8.5 & 0.47 & 21 . & 321 & -- & 0.183 & $<0.2$ \\
\hline $91-2$ & 219 & 55 & 6.7 & .28 & 26 & 321 & $<0.1$ & .316 & $<.2$ \\
\hline $91-3$ & 255 & 80 & 16 & .34 & 25 & 433 & $<.1$ & 4.48 & $<.2$ \\
\hline $91-4$ & 218 & 56 & 8.9 & 1.0 & 17 & 325 & $<1$ & .360 & $<.2$ \\
\hline $91-5$ & 235 & 75 & 11 & .35 & 25 & 416 & $<<1$ & 7.38 & $<.2$ \\
\hline $91-6$ & 215 & 60 & 8.7 & .40 & 26 & 333 & $<.1$ & .450 & $<.2$ \\
\hline $91-7$ & 223 & 57 & 9.7 & .34 & 29 & 346 & $<.1$ & 1.06 & $<.2$ \\
\hline $92-1$ & 257 & 58 & 17 & .23 & 51 & 408 & -. & .107 & $<.2$ \\
\hline 92.2 & 222 & 64 & 8.3 & .51 & 25 & 343 & .. & $<.050$ & $<.2$ \\
\hline $92-4$ & 225 & 62 & 6.8 & .32 & 23 & 338 & $<.1$ & .334 & $<.2$ \\
\hline $92-5$ & 207 & 57 & 11 & .24 & 41 & 343 & $<.1$ & .500 & $<.2$ \\
\hline $92-6$ & 182 & 130 & 9.9 & 1.0 & 21 & 408 & $<.1$. & .207 & $<.2$ \\
\hline $92-7$ & 178 & 150 & 10 & 1.0 & 15 & 424 & $<.1$ & .138 & $<.2$ \\
\hline $92-8$ & 168 & 150 & 12 & 1.0 & 27 & 417 & $<.1$ & .298 & $<.2$ \\
\hline $92-9$ & 186 & 130 & 10 & 1.1 & 20 & 413 & $<.1$ & .465 & $<.2$ \\
\hline $92-10$ & 210 & 81 & 9.1 & .86 & 19 & 358 & $<.1$ & .730 & $<.2$ \\
\hline $92-11$ & 206 & 120 & 19 & 1.1 & 19 & 430 & $<.1$ & 1.02 & $<.2$ \\
\hline $92-12$ & 137 & 47 & 6.9 & .60 & 81 & 306 & $<.1$ & .420 & $<.2$ \\
\hline $92-13$ & 242 & 72 & 9.3 & .34 & 23 & 394 & $<.1$ & 3.12 & $<.2$ \\
\hline $92-14$ & 219 & 57 & 8.1 & .33 & 30 & 348 & $<.1$ & 1.47 & $<.2$ \\
\hline $92-15$ & 155 & 30 & 4.9 & .36 & $67^{\circ}$ & 279 & $<.1$ & .380 & $<.2$ \\
\hline $92-16$ & 176 & 79 & 8.8 & .66 & 30 & 338 & $<.1$ & .311 & $<.2$ \\
\hline $92-17$ & 187 & 59 & 6.7 & .65 & 74 & 365 & - & .176 & $<.2$ \\
\hline $92-18$ & 246 & 99 & 14 & .36 & 36 & 440 & -- & .913 & $<.2$ \\
\hline $92-19$ & 219 & 71 & 9.4 & .40 & 24 & 355 & $<.1$ & .726 & $<.2$ \\
\hline $92-20$ & 248 & 110 & 13 & .43 & 23 & 447 & $<.1$ & 1.12 & $<.2$ \\
\hline $92-21$ & 153 & 86 & 10 & .62 & 72 & 364 & $<.1$ & .214 & $<.2$ \\
\hline $92-22$ & 223 & 89 & 11 & .51 & 21 & 386 & $<.1$ & 1.31 & $<.2$ \\
\hline $92-23$ & 210 & 120 & 15 & .04 & 20 & 429 & $<.1$ & 1.23 & $<.2$ \\
\hline $92-24$ & 243 & 140 & 19 & .58 & 20 & 498 & $<.1$ & 2.87 & $<.2$ \\
\hline $92-25$ & 188 & 110 & 12 & .44 & 19 & 391 & $<.2$ & .156 & $<.2$ \\
\hline $92-26$ & 249 & 110 & 22 & .42 & 36 & 500 & $<.1$ & 5.07 & $<.2$ \\
\hline $92-27$ & 118 & 8.8 & 9.3 & .06 & 18 & 171 & $<.1$ & 1.60 & $<.2$ \\
\hline $92-28$ & 163 & 72 & 12 & .28 & 39 & 328 & $<.1$ & 1.77 & $<.2$ \\
\hline $92-29$ & 230 & 91 & 17 & .45 & 25 & 420 & $<.1$ & 2.58 & $<.2$ \\
\hline $92-30$ & 267 & 100 & 13 & .44 & 28 & 449 & $<.1$ & .150 & $<.2$ \\
\hline $92-32$ & 193 & 95 & 13 & .51 & 22 & 365 & $<.1$ & .300 & $<.2$ \\
\hline $92-33$ & 208 & 100 & 12 & .67 & 23 & 385 & $<.1$ & .120 & $<.2$ \\
\hline W2 & 259 & 95 & 16 & .30 & 26 & 449 & -- & $\ldots$ & -- \\
\hline w3 & 220 & 130 & 17 & .60 & 28 & 456 & -- & - & -- \\
\hline W25 & 202 & 47 & 11 & .20 & 33 & 316 & -. & -. & -- \\
\hline W26 & 202 & 120 & 13 & .67 & 21 & 407 & $<.1$ & .549 & $<.2$ \\
\hline w30 & 204 & 120 & 21 & .70 & 18 & 414 & -- & $-\infty$ & . -- \\
\hline W32 & 211 & 47 & 14 & .20 & 36 & 326 & - & - & .- \\
\hline W35 & 188 & 120 & 12 & 1.0 & 18 & 393 & - & -. & - \\
\hline W38 & 174 & 160 & 11 & 1.1 & 14 & 422 & -- & - & - \\
\hline & & & & & Springs & & & & \\
\hline SPI & 189 & 160 & 13 & 1.1 & 14 & 436 & -- & -. & -- \\
\hline SP2 & 139 & 6.9 & 3.0 & .08 & 17 & 164 & $<.1$ & .129 & $<.2$ \\
\hline \multicolumn{10}{|c|}{ Surface-water sites } \\
\hline sw2 & 360 & 110 & 18 & .63 & 31 & 567 & $<.1$ & .182 & $<.2$ \\
\hline SW3 & 207 & 57 & 6.2 & .42 & 18 & 303 & $<.1$ & .050 & $<.2$ \\
\hline SW4 & 189 & 87 & 11 & .54 & 18 & 345 & $<.1$ & .100 & $<.2$ \\
\hline SW5 & 212 & 58 & 6.3 & .41 & 19 & 312 &.- & .050 & $<.2$ \\
\hline
\end{tabular}


Table 4. Physical characteristics, inorganic constituents, and trace elements in ground- and surface-water samples collected by the U.S. Geological Survey in the lower Blacktail Deer Creek area near Dillon, Montana, 1991 and 1993-94 (Continued)

\begin{tabular}{|c|c|c|c|c|c|c|c|c|c|}
\hline $\begin{array}{c}\text { Site } \\
\text { number } \\
\text { (fig. 4) }\end{array}$ & $\begin{array}{l}\text { Phosphorus, } \\
\text { ortho } \\
\text { (mg/L as P) }\end{array}$ & $\begin{array}{c}\text { Aluminum } \\
(\mu g / L)\end{array}$ & $\begin{array}{c}\text { Antimony } \\
(\mu g / L)\end{array}$ & $\begin{array}{c}\text { Arsenlc } \\
(\mu \mathrm{gL})\end{array}$ & $\begin{array}{c}\text { Barium } \\
(\mu g / L)\end{array}$ & $\begin{array}{c}\text { Beryllium } \\
(\mu \mathrm{g} / \mathrm{L})\end{array}$ & $\begin{array}{l}\text { Boron } \\
(\mu g / L)\end{array}$ & $\begin{array}{c}\text { Bromide } \\
(\mu g / L)\end{array}$ & $\underset{(\mu g / L)}{\text { Cadmium }}$ \\
\hline \multicolumn{10}{|c|}{ Wells } \\
\hline $91-1$ & $<0.15$ & $<30$ & $<2$ & 3 & 53 & $<$ & $<30$ & $<100$ & $<2$ \\
\hline $91-2$ & $<.15$ & $<30$ & $<2$ & 2 & 70 & $<$ & $<30$ & $<100$ & $<2$ \\
\hline $91-3$ & $<.15$ & $<30$ & $<2$ & 2 & 86 & $<$ & 30 & $<100$ & $<2$ \\
\hline $91-4$ & $<15$ & $<30$ & $<2$ & 4 & 35 & $<$ & 40 & $<50$ & $<2$ \\
\hline $91-5$ & $<.15$ & $<30$ & $<2$ & 2 & 73 & $<$ & $<30$ & $<50$ & $<2$ \\
\hline $91-6$ & $<.15$ & $<30$ & $<2$ & 2 & 67 & $<2$ & $<30$ & $<50$ & $<2$ \\
\hline $91-7$ & $<.15$ & $<30$ & $<2$ & 2 & 76 & $<2$ & $<30$ & $<100$ & $<2$ \\
\hline $92-1$ & $<.15$ & $<30$ & $<2$ & 4 & 51 & $<$ & 30 & $<100$ & $<2$ \\
\hline $92-2$ & $<.15$ & $<30$ & $<2$ & 5 & 55 & $<$ & $<30$ & $<100$ & $<2$ \\
\hline $92-4$ & $<.15$ & $<30$ & $<2$ & 2 & 57 & $<$ & $<30$ & $<100$ & $<2$ \\
\hline $92-5$ & $<.15$ & $<30$ & $<2$ & 3 & 63 & $<$ & $<30$ & $<100$ & $<2$ \\
\hline $92-6$ & $<.15$ & $<30$ & $<2$ & 4 & 19 & $<2$ & 110 & $<50$ & $<2$ \\
\hline $92-7$ & $<.15$ & $<30$ & $<2$ & 8 & 25 & $<2$ & 100 & $<50$ & $<2$ \\
\hline $92-8$ & $<.15$ & $<30$ & $<2$ & 6 & 16 & 8 & 140 & $<50$ & $<2$ \\
\hline $92-9$ & $<.15$ & $<30$ & $<2$ & 3 & 25 & $<2$ & 100 & $<50$ & $<2$ \\
\hline $92-10$ & $<.15$ & $<30$ & $<2$ & 4 & 25 & $<2$ & 60 & $<50$ & $<2$ \\
\hline $92-11$ & $<.15$ & $<30$ & $<2$ & 2 & 33 & $<2$ & 70 & 55 & $<2$ \\
\hline $92-12$ & $<.025$ & $<30$ & $<2$ & 22 & 37 & $<2$ & 50 & 39 & $<2$ \\
\hline $92-13$ & $<.025$ & $<30$ & $<2$ & 3 & 45 & $<2$ & 30 & 37 & $<2$ \\
\hline 92.14 & $<.025$ & $<30$ & $<2$ & 3 & 83 & $<2$ & $<30$ & 47 & $<2$ \\
\hline $92-15$ & $<.025$ & $<30$ & $<2$ & 12 & 81 & $<2$ & 30 & 34 & $<2$ \\
\hline $92-16$ & $<.15$ & $<30$ & $<2$ & 16 & 29 & $<$ & 70 & $<100$ & $<2$ \\
\hline $92-17$ & $<.15$ & 30 & $<$ & 13 & 40 & 8 & 90 & $<100$ & $<2$ \\
\hline $92-18$ & $<.15$ & $<30$ & $<2$ & 2 & 46 & 8 & 50 & $<100$ & $<2$ \\
\hline $92-19$ & $<.15$ & $<30$ & $<2$ & 3 & 41 & $<$ & $<30$ & $<100$ & $<2$ \\
\hline $92-20$ & $<.15$ & $<30$ & $<2$ & 3 & 57 & $<$ & 30 & $<100$ & $<$ \\
\hline $92-21$ & $<.15$ & $<30$ & $<2$ & 7 & 32 & 2 & 80 & $<50$ & $<2$ \\
\hline $92-22$ & $<.15$ & $<30$ & $<$ & 3 & 32 & $<$ & 40 & $<50$ & $<2$ \\
\hline $92-23$ & $<.15$ & $<30$ & $<2$ & 2 & 74 & $<2$ & 40 & $<100$ & $<2$ \\
\hline $92-24$ & $<.15$ & $<30$ & $<2$ & 2 & 90 & $<2$ & 40 & $<100$ & $<2$ \\
\hline $92-25$ & $<.15$ & $<30$ & $<$ & 2 & 72 & $<$ & 40 & 46 & $<2$ \\
\hline $92-26$ & $<.15$ & $<30$ & $<2$ & 3 & 92 & $<2$ & 60 & $<50$ & $<2$ \\
\hline $92-27$ & $<.15$ & $<30$ & $<2$ & $<1$ & 61 & $<$ & $<30$ & $<50$ & $<2$ \\
\hline $92-28$. & $<.15$ & $<30$ & $<2$ & 4 & 29 & $<2$ & $<30$ & $<100$ & $<2$ \\
\hline $92-29$ & $<.15$ & $<30$ & $<2$ & 2 & 59 & $<2$ & 40 & $<100$ & $<2$ \\
\hline $92-30$ & $<.15$ & $<30$ & $<2$ & 3 & 54 & $<2$ & 50 & $<100$ & $<2$ \\
\hline $92-32$ & $<.15$ & 30 & $<2$ & 2 & 26. & $<$ & 30 & $<50$ & $<2$ \\
\hline $92-33$ & $<.15$ & $<30$ & $<2$ & 3 & 70 & $<2$ & 50 & $<50$ & $<2$ \\
\hline W2 & - & - & - & - & 60 & $<.5$ & 60 & - & $<1$ \\
\hline W3 & - & - & - & - & 44 & $<.5$ & 120 & - & $<1$ \\
\hline W25 & -- & -- & - & - & 85 & $<.5$ & 40 & - & $<1$ \\
\hline W26 & $<.15$ & $<30$ & $<2$ & 4 & 44 & $<2$ & 50 & 55 & $<2$ \\
\hline W30 & - & - & -- & - & 50 & $<.5$ & 70 & - & $<1$ \\
\hline W32 & - & -- & -- & - & 69 & $<.5$ & 40 & - & $i$ \\
\hline W35 & $\cdots$ & -- & - & - & 30 & $<.5$ & 90 & - & $<1$ \\
\hline W39 & -- & - & - & - & 27 & $<.5$ & 100 & - & $<1$ \\
\hline \multicolumn{10}{|c|}{ Springs } \\
\hline SP1 & -- & - & -- & .- & 32 & $<.5$ & 120 & - & $<1$ \\
\hline SP2 & $<.15$ & $<30$ & $<2$ & $<1$ & 71 & $<$ & $<30$ & $<50$ & $<2$ \\
\hline \multicolumn{10}{|c|}{ Surface-water sites } \\
\hline SW2 & $<.15$ & $<30$ & $<2$ & 5 & 59 & $<$ & 50 & $<100$ & $<2$ \\
\hline SW3 & $<.15$ & $<30$ & $<2$ & 3 & 68 & $<$ & $<30$ & $<100$ & $<2$ \\
\hline SW4 & $<.10$ & $<30$ & $<2$ & 5 & 56 & 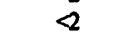 & 40 & 37 & $<2$ \\
\hline SW5 & $<.15$ & $<30$ & $<2$ & 4 & 73 & $<2$ & $<30$ & $<100$ & $<2$ \\
\hline
\end{tabular}


Table 4. Physical characteristics, inorganic constituents, and trace elements in ground- and surface-water samples collected by the U.S. Geological Survey in the lower Blacktail Deer Creek area near Dillon, Montana, 1991 and 1993-94 (Continued)

\begin{tabular}{|c|c|c|c|c|c|c|c|c|}
\hline $\begin{array}{c}\text { Site } \\
\text { number } \\
\text { (fig. 4) }\end{array}$ & $\begin{array}{c}\text { Chromlum } \\
(\mu g / L)\end{array}$ & $\begin{array}{l}\text { Cobalt } \\
(\mu g / \mathrm{L})\end{array}$ & $\begin{array}{c}\text { Copper } \\
(\mu g / L)\end{array}$ & $\begin{array}{c}\text { Iron } \\
(\mu \mathrm{g} / \mathrm{L})\end{array}$ & $\begin{array}{c}\text { Lead } \\
(\mu \mathrm{g} / \mathrm{L})\end{array}$ & $\begin{array}{c}\text { Lithium } \\
(\mu \mathrm{g} / \mathrm{L})\end{array}$ & $\begin{array}{c}\text { Manganese } \\
(\mu \mathrm{g} / \mathrm{L})\end{array}$ & $\begin{array}{c}\text { Molybdenum } \\
(\mu \mathrm{g} / \mathrm{L})\end{array}$ \\
\hline \multicolumn{9}{|c|}{ Wells } \\
\hline $91-1$ & $<2$ & $<2$ & $<2$ & $<3$ & $<2$ & 8 & $<2$ & $<20$ \\
\hline $91-2$ & $<2$ & $<2$ & $<2$ & $<3$ & $<2$ & 9 & $<2$ & $<10$ \\
\hline $91-3$ & $<2$ & $<2$ & $<2$ & $<3$ & $<2$ & 18 & $<2$ & $<10$ \\
\hline $91-4$ & $<2$ & $<2$ & $<2$ & 4 & $<2$ & 39 & $<2$ & $<10$ \\
\hline $91-5$ & $<2$ & $<2$ & $<2$ & $<3$ & $<2$ & 10 & $<2$ & $<10$ \\
\hline $91-6$ & $<2$ & $<2$ & $<2$ & $<3$ & $<2$ & 10 & $<2$ & $<10$ \\
\hline $91-7$ & $<$ & $<2$ & $<2$ & $<3$ & $<2$ & 7 & $<$ & $<10$ \\
\hline $92-1$ & $<2$ & $<2$ & $<2$ & 16 & $<2$ & 10 & 76 & $<20$ \\
\hline $92-2$ & $<2$ & $<2$ & $<2$ & 44 & $<2$ & 7 & $<$ & $<20$ \\
\hline $92-4$ & $<2$ & $<2$ & $<2$ & 62 & $<2$ & 10 & 5 & $<10$ \\
\hline $92-5$ & $<2$ & $<2$ & $<2$ & 17 & $<2$ & 11 & 2 & $<10$ \\
\hline $92-6$ & $<2$ & 2 & $<2$ & 56 & $<2$ & 41 & 17 & $<10$ \\
\hline $92-7$ & $<2$ & $<$ & $<2$ & 4 & $<2$ & 48 & $<$ & $<10$ \\
\hline $92-8$ & $<$ & $<2$ & $<2$ & 75 & $<2$ & 54 & 13 & $<10$ \\
\hline $92-9$ & $<2$ & $<2$ & $<2$ & 53 & $<2$ & 45 & 46 & $<10$ \\
\hline $92-10$ & $<2$ & $<2$ & $<2$ & 19 & $<2$ & 42 & 3 & $<10$ \\
\hline $92-11$ & $<2$ & $<2$ & $<2$ & 36 & $<2$ & 41 & 4 & $<10$ \\
\hline $92-12$ & 10 & $<2$ & $<2$ & 520 & $<2$ & 18 & 6 & $<10$ \\
\hline $92-13$ & $<2$ & $<2$ & $<2$ & 40 & $<2$ & 15 & 2 & $<10$ \\
\hline $92-14$ & $<2$ & $<2$ & $<2$ & 17 & $<2$ & 12 & 2 & $<10$ \\
\hline $92-15$ & $<2$ & $<2$ & $<2$ & 140 & $<2$ & 18 & 46 & $<10^{\circ}$ \\
\hline $92-16$ & $<$ & $<2$ & $<2$ & 150 & $<2$ & 39 & 91 & $<10$ \\
\hline $92-17$ & $<$ & $<2$ & $<2$ & 27 & $<2$ & 50 & 34 & $<20$ \\
\hline $92-18$ & $<2$ & $<2$ & 2 & 42 & $<2$ & 12 & 3 & $<20$ \\
\hline $92-19$ & $<$ & $<2$ & $<2$ & 58 & $<2$ & 10 & 6 & $<10$ \\
\hline $92-20$ & $<2$ & $<2$ & $<2$ & 57 & $<2$ & 18 & 2 & $<10$ \\
\hline $92-21$ & $<$ & $<2$ & $<2$ & 50 & $<2$ & 33 & 130 & $<10$ \\
\hline $92-22$ & 2 & $<2$ & $<2$ & 9 & $<2$ & 30 & 3 & $<10$ \\
\hline $92-23$ & $<2$ & $<2$ & $<2$ & 120 & $<2$ & 18 & 2 & $<10$ \\
\hline $92-24$ & 2 & $<2$ & $<2$ & 41 & $<2$ & 20 & $<2$ & $<10$ \\
\hline $92-25$ & $<2$ & $<2$ & $<2$ & 68 & $<2$ & 21 & 5 & $<10$ \\
\hline $92-26$ & $<2$ & $<2$ & $<2$ & 7 & $<2$ & 16 & $<2$ & $<10$ \\
\hline $92-27$ & $<$ & $<2$ & $<2$ & 21 & $<2$ & $<6$ & 2 & $<10$ \\
\hline $92-28$ & $<2$ & $<2$ & $<2$ & 130 & $<2$ & 16 & 23 & $<10$ \\
\hline $92-29$ & $<2$ & $<2$ & $<2$ & 150 & $<2$ & 14 & 11 & $<10$ \\
\hline $92-30$ & $<2$ & $<2$ & $<2$ & 130 & $<2$ & 25 & 60 & $<10$ \\
\hline $92-32$ & $<2$ & $<2$ & $<2$ & 150 & $<2$ & 21 & 17 & $<10$ \\
\hline $92-33$ & $<2$ & $<2$ & $<2$ & 55 & $<2$ & 28 & 3 & $<10$ \\
\hline W2 & $<5$ & $<3$ & $<10$ & 7 & $<10$ & 23 & $<1$ & $<10$ \\
\hline W3 & $<5$ & $<3$ & $<10$ & 10 & $<10$ & 23 & $<1$ & $<10$ \\
\hline W25 & $<5$ & $<3$ & $<10$ & 6 & 10 & 13 & $<1$ & $<10$ \\
\hline W26 & $<2$ & $<2$ & $<2$ & 4 & $<2$ & 38 & $<2$ & $<10$ \\
\hline W30 & $<5$ & $<3$ & $<10$ & 12 & $<10$ & 41 & $<1$ & $<10$ \\
\hline W32 & $<5$ & $<3$ & $<10$ & 8 & 10 & 16 & $<i$ & $<10$ \\
\hline W35 & $<5$ & $<3$ & $<10$ & 14 & $<10$ & 50 & 1 & $<10$ \\
\hline W38 & $<5$ & $<3$ & $<10$ & 12 & $<10$ & 56 & 4 & $<10$ \\
\hline & & & & Spring & & & & \\
\hline SP1 & $<5$ & $<3$ & $<10$ & 6 & $<10$ & 56 & 3 & $<10$ \\
\hline SP2 & $<2$ & $<2$ & 6 & $<3$ & $<2$ & $<6$ & $<2$ & $<10$ \\
\hline & & & & Surface-wat & & & & \\
\hline SW2 & $<2$ & $<2$ & $<2$ & 30 & $<2$ & 26 & 42 & $<10$ \\
\hline SW3 & $<2$ & $<2$ & $<2$ & 5 & $<2$ & 7 & $<2$ & $<10$ \\
\hline SW4 & $<$ & $<2$ & $<2$ & 21 & $<2$ & 18 & 31 & $<10$ \\
\hline sw5 & $<2$ & $<$ & $<2$ & 8 & $<2$ & 7 & 7 & $<20$ \\
\hline
\end{tabular}


Table 4. Physical characteristics, inorganic constituents, and trace elements in ground- and surface-water samples collected by the U.S. Geological Survey in the lower Blacktail Deer Creek area near Dillon, Montana, 1991 and 1993-94 (Continued)

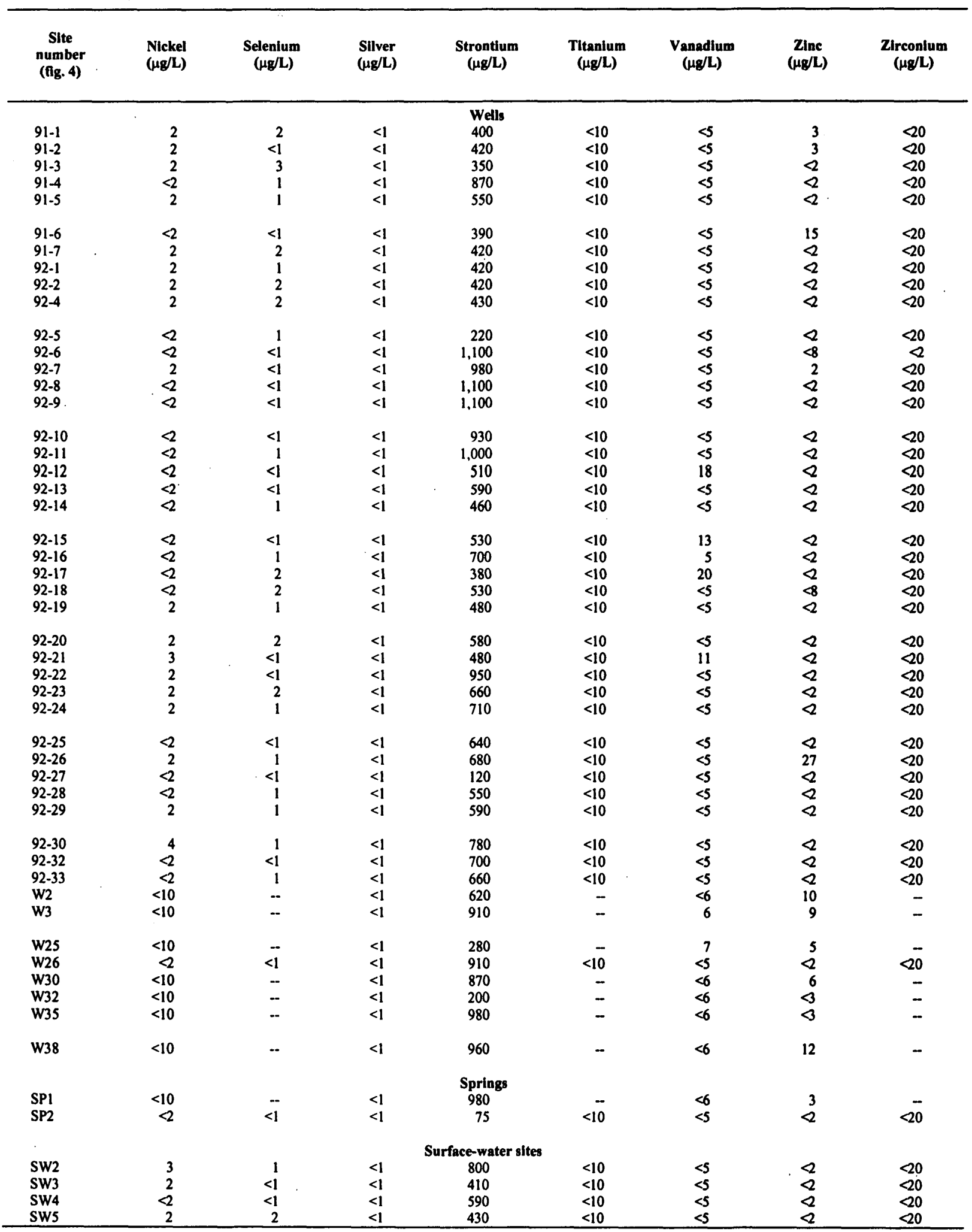


Table 5. Physical characteristics, inorganic constituents, and trace elements in ground- and surface-water samples collected by the University of Montana in the lower Blacktail Deer Creek area near Dillon, Montana, 1993

[Site number described in text. Analyses by the University of Montana. Concentration data are dissolved. Abbreviations: ${ }^{\circ} \mathrm{C}$, degrees Celsius; mg/L, milligrams per liter, $\mu \mathrm{g} / \mathrm{L}$, micrograms per liter. Symbols: <, less than minimum reporting level; --, no data]

\begin{tabular}{|c|c|c|c|c|c|c|c|c|c|c|}
\hline $\begin{array}{c}\text { Site } \\
\text { number } \\
\text { (fig. 4) }\end{array}$ & Date & $\begin{array}{l}\text { pH, } \\
\text { onsite } \\
\text { (stand- } \\
\text { ard } \\
\text { units) }\end{array}$ & $\begin{array}{c}\text { Temper- } \\
\text { ature, } \\
\text { water } \\
\text { (ㄷ) }\end{array}$ & $\begin{array}{l}\text { Calclum } \\
\text { (mg/L) }\end{array}$ & $\begin{array}{c}\text { Magne- } \\
\text { slum } \\
\text { (mg/L) }\end{array}$ & $\begin{array}{l}\text { Sodium } \\
\text { (mg/L) }\end{array}$ & $\begin{array}{l}\text { Potas- } \\
\text { sium } \\
(\mathbf{m g / L})\end{array}$ & $\begin{array}{c}\text { Alka- } \\
\text { linity } \\
\text { (mg/L as } \\
\left.\mathrm{CaCO}_{3}\right)\end{array}$ & $\begin{array}{l}\text { Sulfate } \\
(\mathrm{mg} / \mathrm{L})\end{array}$ & $\begin{array}{l}\text { Chloride } \\
(\mathrm{mg} / \mathrm{L})\end{array}$ \\
\hline & & & & & Wells & & & & & \\
\hline WI & $11-14-93$ & 7.4 & 7.1 & 140 & 42 & 58 & 7.7 & 340 & 112 & 16 \\
\hline W4 & $11-14-93$ & 7.6 & 7.8 & 91 & 31 & 20 & 9.8 & 246 & 99 & 13 \\
\hline W5 & $11-14-93$ & 7.8 & 5.9 & 100 & 35 & 22 & 9.3 & 252 & 110 & 16 \\
\hline W6 & $12-06-93$ & 7.5 & 9.4 & 95 & 27 & 16 & 11.8 & 248 & 82 & 26 \\
\hline w7 & $12-06-93$ & 7.3 & 10 & 88 & 26 & 15 & 6.3 & 188 & 110 & 10 \\
\hline w9 & $12-11-93$ & 7.3 & 16.4 & 93 & 32 & 12 & 7.0 & 158 & 160 & 6.0 \\
\hline W10 & $11-14-93$ & 7.7 & 6.3 & 91 & 25 & 22 & 6.7 & 208 & 100 & 13 \\
\hline W12 & $12-06-93$ & 7.1 & 9.6 & 93 & 27 & 26 & 7.2 & 256 & 110 & 19 \\
\hline W13 & $12-11-93$ & 7.3 & 8.3 & 65 & 11 & 13 & 4.7 & 206 & 13 & 9.0 \\
\hline W15 & $12-06-93$ & 7.1 & 9.8 & 110 & 33 & 29 & 7.9 & 222 . & 160 & 16 \\
\hline W16 & $12-11-93$ & 7.2 & 8.9 & 130 & 39 & 27 & 10.6 & 270 & 100. & 82 \\
\hline W17 & $12-06-93$ & 7.5 & 14.1 & 94 & 26 & 25 & 7.4 & 244 & 110 & 16 \\
\hline W19 & $12-06-93$ & 7.2 & 10.4 & 98 & 30 & 26 & 8.0 & 256 & 120 & 17 \\
\hline W20 & $12-11-93$ & 7.2 & 8.4 & 78 & 22 & 12 & 8.4 & 226 & 54 & 8.0 \\
\hline W22 & $11-14-93$ & 7.8 & 6.4 & 98 & 28 & 29 & 7.2 & 262 & 130 & 14 \\
\hline W23 & $12-11-93$ & 7.4 & 8.8 & 82 & 23 & 11 & 7.2 & 228 & 59 & 10 \\
\hline W24 & $12-06-93$ & 7.1 & 10.7 & 95 & 27 & 25 & 7.1 & 264 & 110 & 15 \\
\hline W26 & $11-14-93$ & 8.0 & 7.7 & 80 & 26 & 22 & 7.4 & 202 & 110 & 18 \\
\hline W29 & $11-14-93$ & 8.1 & 6.0 & 130 & 38 & 38 & 7.9 & 242 & 240 & 14 \\
\hline W31 & $12-11-93$ & 7.2 & 7.9 & 88 & 25 & 15 & 7.5 & 250 & 78 & 11 \\
\hline W33 & $12-11-93$ & 7.1 & 9.3 & 84 & 25 & 14 & 6.7 & -- & 69 & 8.9 \\
\hline \multicolumn{11}{|c|}{ Surface-water sites } \\
\hline SWI & $12-06-93$ & - & 1.2 & 78 & 26 & 23 & 7.6 & 220 & 93 & 12 \\
\hline SW4 & $12-06-93$ & - & 1.0 & 73 & 25 & 23 & 7.3 & 204 & 91 & 14 \\
\hline
\end{tabular}


Table 5. Physical characteristics, inorganic constituents, and trace elements in ground- and surface-water samples collected by the University of Montana in the lower Blacktail Deer Creek area near Dillon, Montana, 1993 (Continued)

\begin{tabular}{|c|c|c|c|c|c|c|c|c|c|}
\hline $\begin{array}{c}\text { Site } \\
\text { number } \\
\text { (fig. 4) }\end{array}$ & $\begin{array}{c}\text { Silica } \\
\left(\mathrm{mg}^{2} \mathrm{~L} \text { as }\right. \\
\left.\mathrm{SiO}_{2}\right)\end{array}$ & $\begin{array}{l}\text { Nitrate } \\
\text { (mg/L } \\
\text { as N) }\end{array}$ & $\begin{array}{l}\text { Phos- } \\
\text { phorus } \\
\text { (mg/L } \\
\text { as P) }\end{array}$ & $\begin{array}{l}\text { Phos- } \\
\text { phate } \\
\text { (mg/L as } \\
\text { P) }\end{array}$ & $\begin{array}{c}\text { Aluminum } \\
(\mu \mathrm{g} / \mathrm{L})\end{array}$ & $\begin{array}{c}\text { Arsenic } \\
(\mu \mathrm{g} / \mathrm{L})\end{array}$ & $\begin{array}{l}\text { Boron } \\
(\mu g / L)\end{array}$ & $\begin{array}{c}\text { Cadmlum } \\
(\mu \mathrm{g} / \mathrm{L})\end{array}$ & $\begin{array}{c}\text { Chromium } \\
(\mu \mathrm{g} / \mathrm{L})\end{array}$ \\
\hline \multicolumn{10}{|c|}{ Wells } \\
\hline W1 & 16 & 5.59 & 0.24 & $<0.5$ & $<200$ & $<95$ & 69 & $<$ & $<15$ \\
\hline W4 & 18 & 3.62 & .26 & $<.5$ & $<200$ & $<95$ & 38 & $<7$ & $<15$ \\
\hline w5 & 20 & 5.04 & .13 & $<.5$ & $<200$ & $<95$ & 41 & $<7$ & $<15$ \\
\hline W6 & 25 & 2.39 & .27 & $<.5$ & $<200$ & $<95$ & 24 & $<7$ & $<15$ \\
\hline W7 & 11 & 1.47 & .27 & $<.5$ & $<200$ & $<95$ & 30 & $<7$ & $<15$ \\
\hline w9 & 9 & 1.26 & .54 & $<.5$ & $<200$ & $<95$ & 48 & $<$ & $<15$ \\
\hline W10 & 12 & 1.81 & .41 & $<.5$ & $<200$ & $<95$ & 45 & $<7$ & $<15$ \\
\hline W12 & 11 & 1.20 & .32 & $<.5$ & $<200$ & $<95$ & 39 & $<7$ & $<15$ \\
\hline W13 & 14 & 1.05 & .36 & $<.5$ & $<200$ & $<95$ & 22 & $<$ & $<15$ \\
\hline W15 & 11 & 1.88 & .31 & $<.5$ & $<200$ & $<95$ & 53 & $<7$ & $<15$ \\
\hline W16 & 20. & 5.66 & .44 & $<.5$ & $<200$ & $<95$ & 61 & $<7$ & $<15$ \\
\hline W17 & 12 & .55 & .37 & $<.5$ & $<200$ & $<95$ & 48 & $<7$ & $<15$ \\
\hline W19 & 12 & 1.24 & .38 & $<.5$ & $<200$ & $<95$ & 52 & $<$ & $<15$ \\
\hline W20 & 16 & .50 & .44 & $<.5$ & $<200$ & $<95$ & 27 & $<7$ & $<15$ \\
\hline W22 & 13 & 1.19 & .40 & $<.5$ & $<200$ & $<95$ & 79 & $<7$ & $<15$ \\
\hline W23 & 12 & 1.01 & .47 & $<.5$ & $<200$ & $<95$ & 26 & $<$ & $<15$ \\
\hline W24 & 12 & .31 & .33 & $<.5$ & $<200$ & $<95$ & 46 & 7 & $<15$ \\
\hline W26 & $\ddot{9}$ & 1.29 & .24 & $<.5$ & $<200$ & $<95$ & 48 & $<$ & $<15$ \\
\hline W29 & 12 & .76 & .25 & $<.5$ & $<200$ & $<95$ & 120 & $<7$ & $<15$ \\
\hline W31 & 10 & 2.58 & .42 & $<.5$ & $<200$ & $<95$ & 38 & $<7$ & $<15$ \\
\hline W33 & 10 & 1.53 & .32 & $<.5$ & $<200$ & $<95$ & 40 & $<7$ & $<15$ \\
\hline \multicolumn{10}{|c|}{ Surface-water sites } \\
\hline SW1 & 10 & $<.01$ & .39 & $<.5$ & $<200$ & $<95$ & 38 & $<7$ & $<15$ \\
\hline SW4 & 9 & .16 & .25 & $<.5$ & $<200$ & $<95$ & 34 & $<7$ & $<15$ \\
\hline
\end{tabular}


Table 5. Physical characteristics, inorganic constituents, and trace elements in ground- and surface-water samples collected by the University of Montana in the lower Blacktail Deer Creek area near Dillon, Montana, 1993 (Continued)

\begin{tabular}{|c|c|c|c|c|c|c|c|c|c|c|}
\hline $\begin{array}{c}\text { Site } \\
\text { number } \\
\text { (6g. 4) }\end{array}$ & $\begin{array}{l}\text { Cobalt } \\
(\mu g / L)\end{array}$ & $\begin{array}{l}\text { Copper } \\
(\mu g / L)\end{array}$ & $\begin{array}{c}\text { Iron } \\
(\mu g / L)\end{array}$ & $\begin{array}{c}\text { Lead } \\
(\mu g / L)\end{array}$ & $\begin{array}{c}\text { Manganese } \\
(\mu g / L)\end{array}$ & $\begin{array}{l}\text { Molyb- } \\
\text { denum } \\
(\mu / / L)\end{array}$ & $\begin{array}{l}\text { Nickel } \\
(\mu g / L)\end{array}$ & $\begin{array}{l}\text { Strontium } \\
(\mu \mathrm{g} / L)\end{array}$ & $\begin{array}{c}\text { Titanlum } \\
(\mu g / L)\end{array}$ & $\underset{(\mu g / L)}{\text { Zinc }}$ \\
\hline \multicolumn{11}{|c|}{ Wells } \\
\hline W1 & $<5$ & $<35$ & 2,000 & $<60$ & 2,300 & $<5$ & $<40$ & 840 & 15 & 89 \\
\hline W4 & $<5$ & $<35$ & $<15$ & $<60$ & $<5$ & $<5$ & $<40$ & 530 & 15 & 44 \\
\hline WS & $<5$ & $<35$ & $<15$ & $<60$ & $<5$ & $<5$ & $<40$ & 620 & 8 & 78 \\
\hline W6 & $<5$ & $<35$ & $<15$ & $<60$ & $<5$ & $<5$ & $<40$ & 640 & 17 & 34 \\
\hline w7 & $<5$ & $<35$ & 37 & $<60$ & $<5$ & $<5$ & $<40$ & 640 & 17 & 43 \\
\hline W9 & $<5$ & $<35$ & $<15$ & $<60$ & $<5$ & 6 & $<40$ & 780 & 29 & 31 \\
\hline W10 & $<5$ & $<35$ & $<15$ & $<60$ & $<5$ & $<5$ & $<40$ & 490 & 23 & 63 \\
\hline W12 & $<5$ & $<35$ & $<15$ & $<60$ & $<5$ & $<5$ & $<40$ & 590 & 19 & 93 \\
\hline W13 & $<5$ & $<35$ & $<15$ & $<60$ &,$\quad<5$ & $<5$ & $<40$ & 180 & 19 & 118 \\
\hline W15 & $<5$ & $<35$ & 24 & $<60$ & $<5$ & $<5$ & $<40$ & 820 & 17 & 60 \\
\hline W16 & $<5$ & $<35$ & $<15$ & $<60$ & $<5$ & $<5$ & $<40$ & 510 & 25 & 43 \\
\hline W17 & $<5$ & $<35$ & $<15$ & $<60$ & $<5$ & $<5$ & $<40$ & 540 & 22. & 19 \\
\hline W19 & $<5$ & $<35$ & $<15$ & $<60$ & $<5$ & $<5$ & $<40$ & 620 & 22 & 69 \\
\hline W20 & $<5$ & $<35$ & $<15$ & $<60$ & $<5$ & $<5$ & $<40$ & 320 & 23 & 35 \\
\hline W22 & $<5$ & $<35$ & 12 & $<60$ & $<5$ & $<5$ & $<40$ & 880 & 21 & 33 \\
\hline W23 & $<5$ & $<35$ & 45 & $<60$ & $<5$ & $<5$ & $<40$ & 370 & 27 & 40 \\
\hline W24 & $<5$ & $<35$ & $<15$. & $<60$ & $<5$ & $<5$ & $<40$ & 600 & 19 & 20 \\
\hline W26 & $<5$ & $<35$ & $<15$ & $<60$ & $<5$ & $<5$ & $<40$ & 740 & 15 & $<5$ \\
\hline W29 & $<5$ & $<35$ & $<15$ & $<60$ & $<5$ & $<5$ & $<40$ & 1,100 & 13 & 33 \\
\hline W31 & $<5$ & $<35$ & $<15$ & $<60$ & $<5$ & $<5$ & $<40$ & 500 & 24 & 37 \\
\hline \multirow[t]{2}{*}{ w33 } & $<5$ & $<35$ & $<15$ & $<60$ & $<5$ & $<5$ & $<40$ & 540 & 20 & 27 \\
\hline & \multicolumn{10}{|c|}{ Surface-water sites } \\
\hline SWI & $<5$ & $<35$ & $<15$ & $<60$ & 6 & $<5$ & $<40$ & 570 & 16 & - \\
\hline SW4 & $<5$ & $<35$ & $<15$ & $<60$ & $<5$ & $<5$ & $<40$ & 550 & 15 & - \\
\hline
\end{tabular}




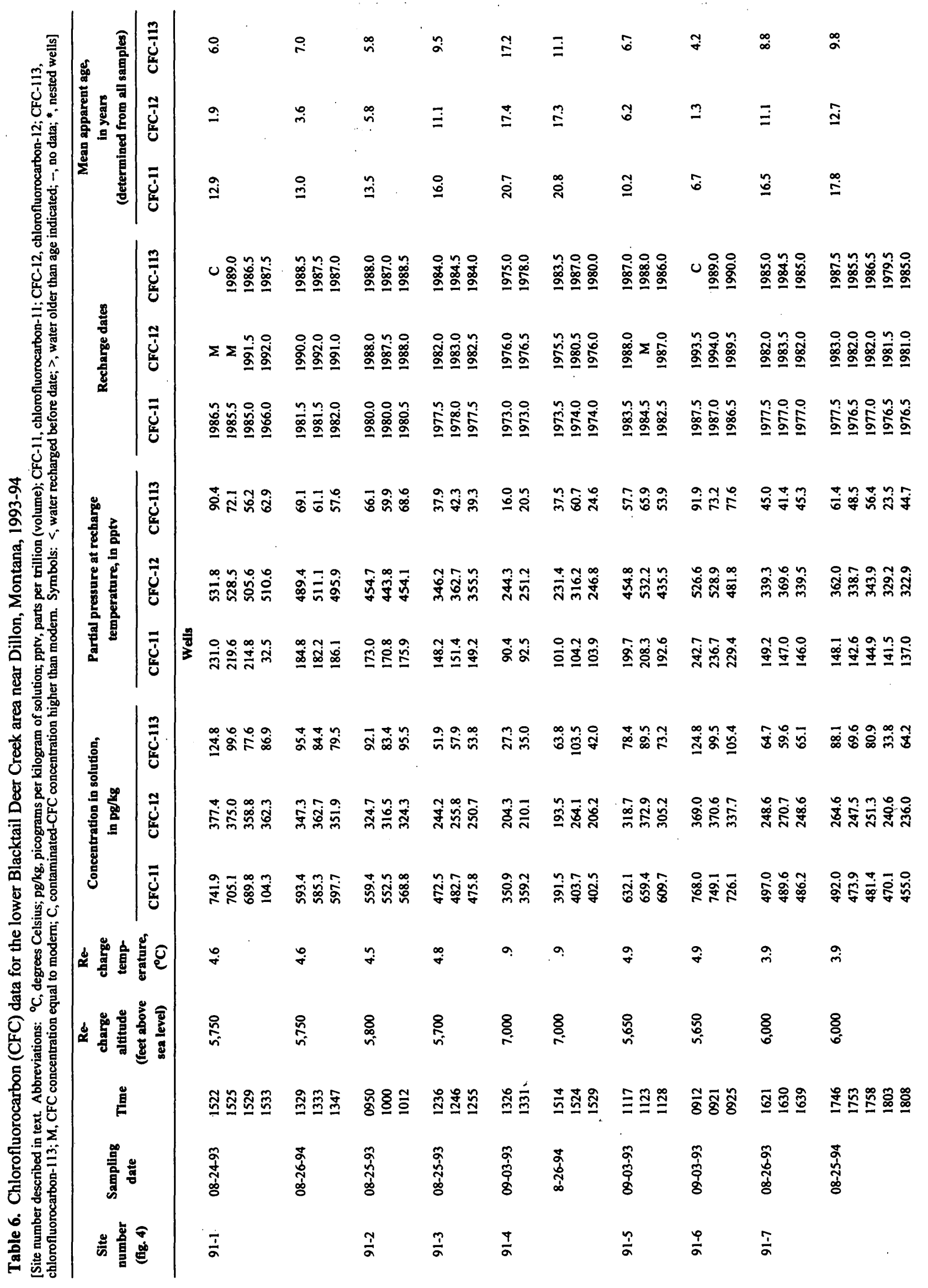




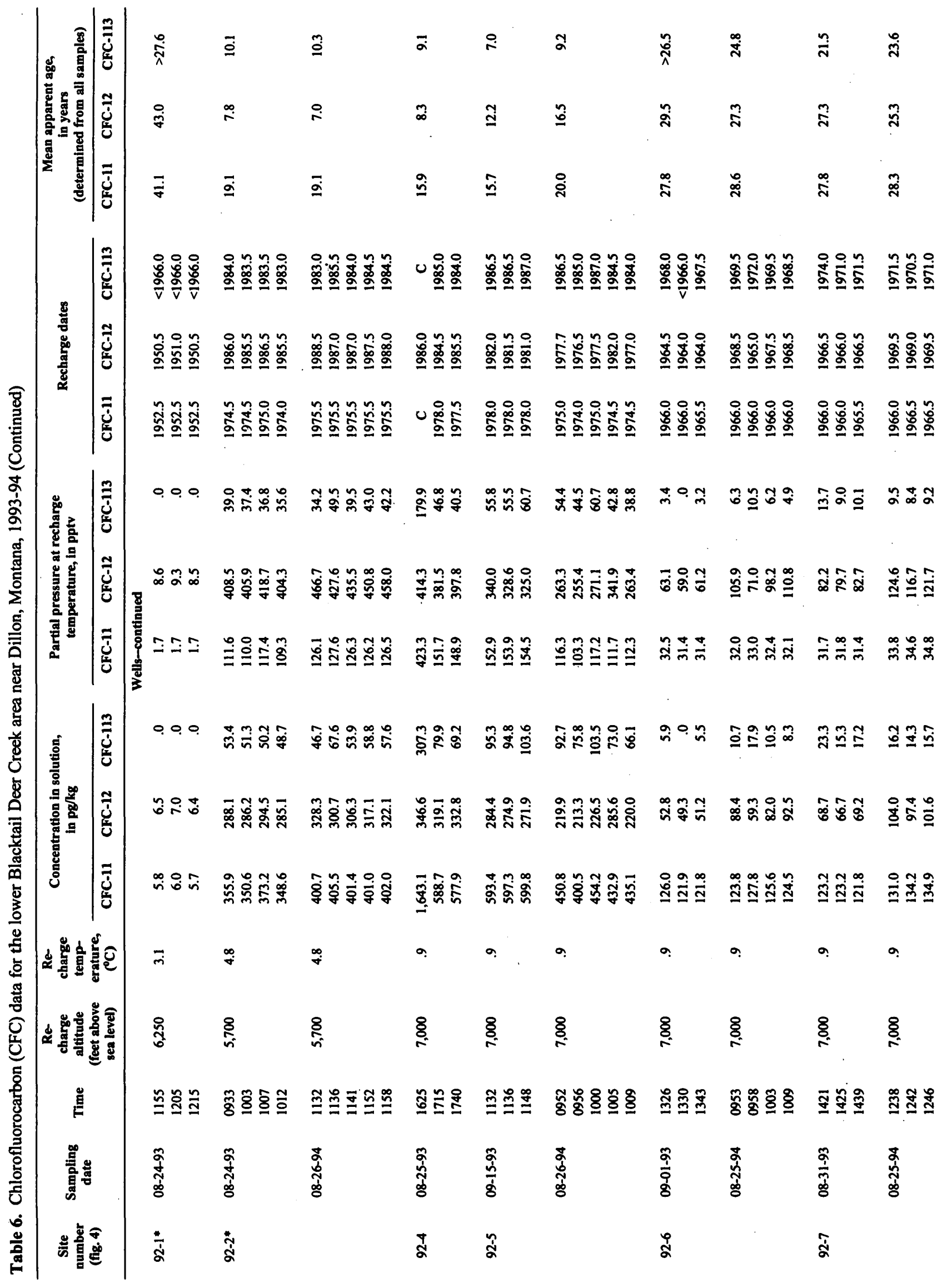




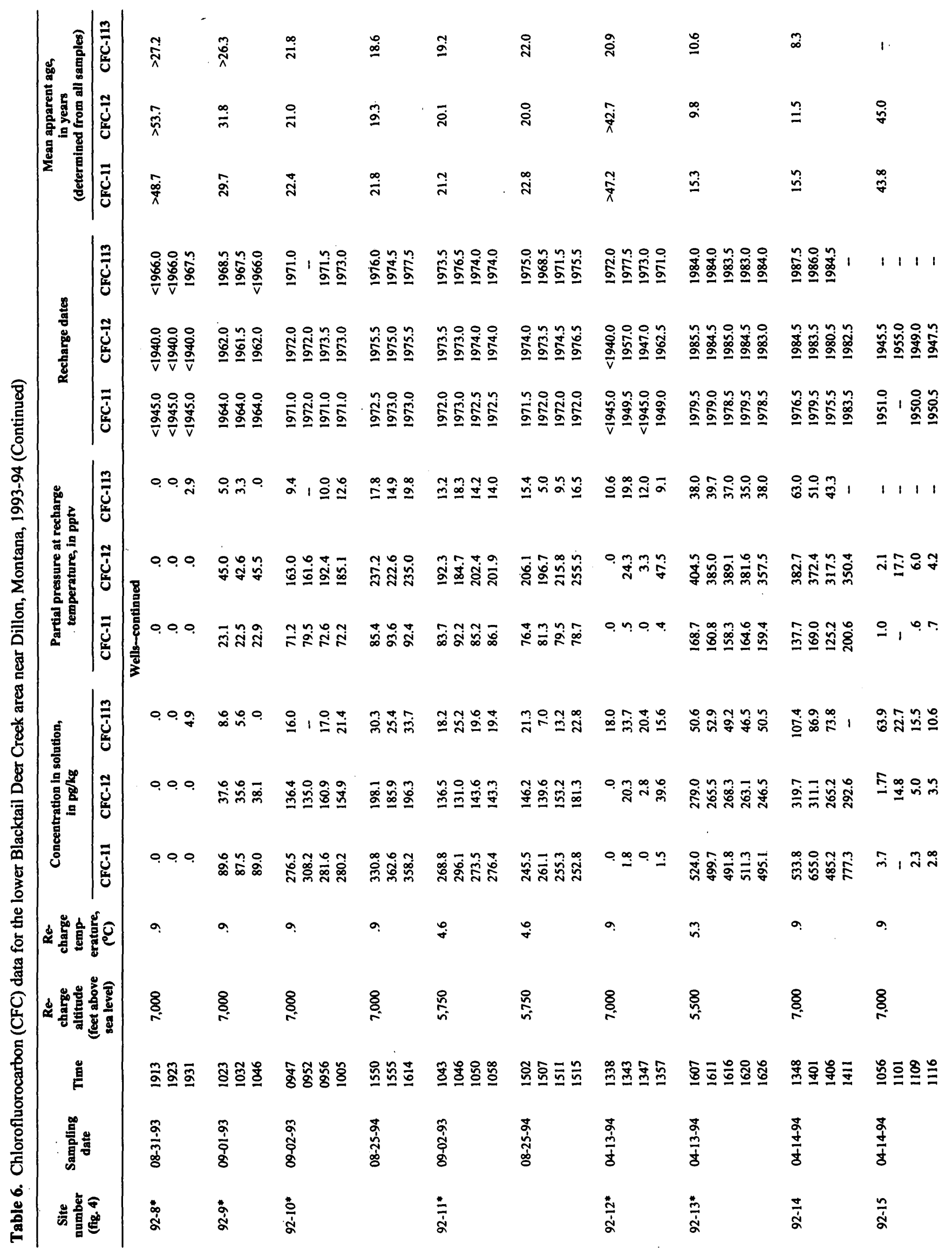




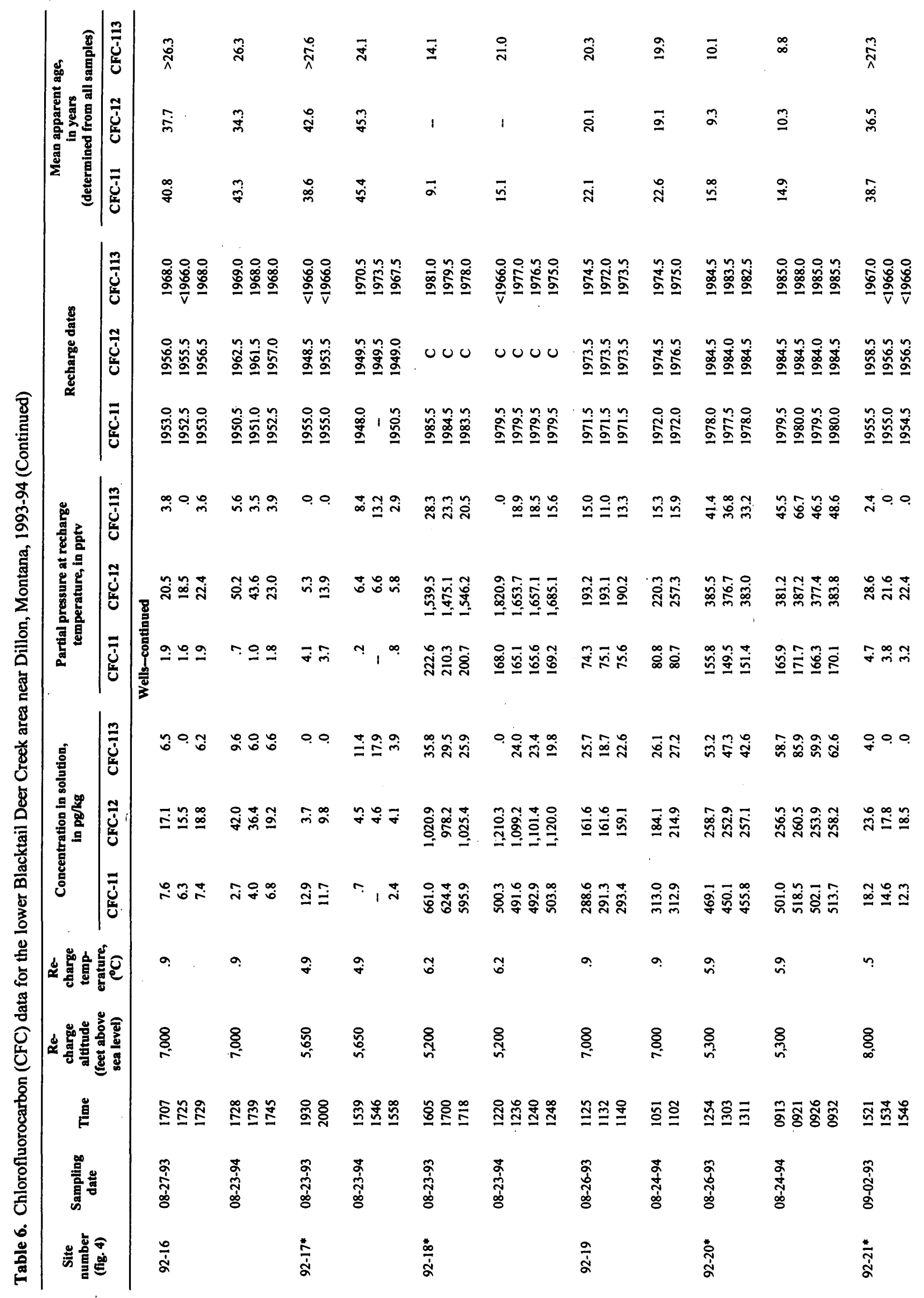




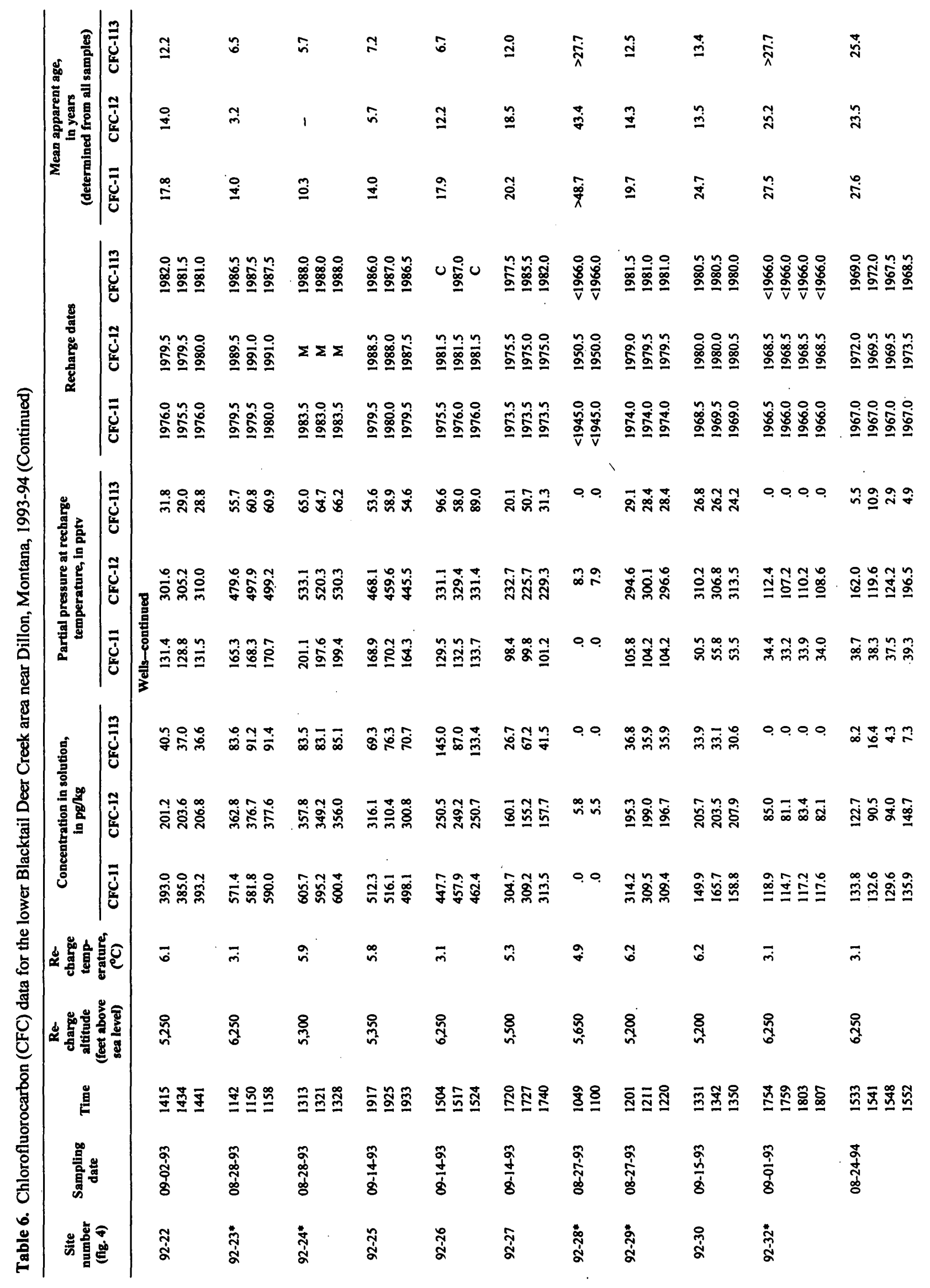




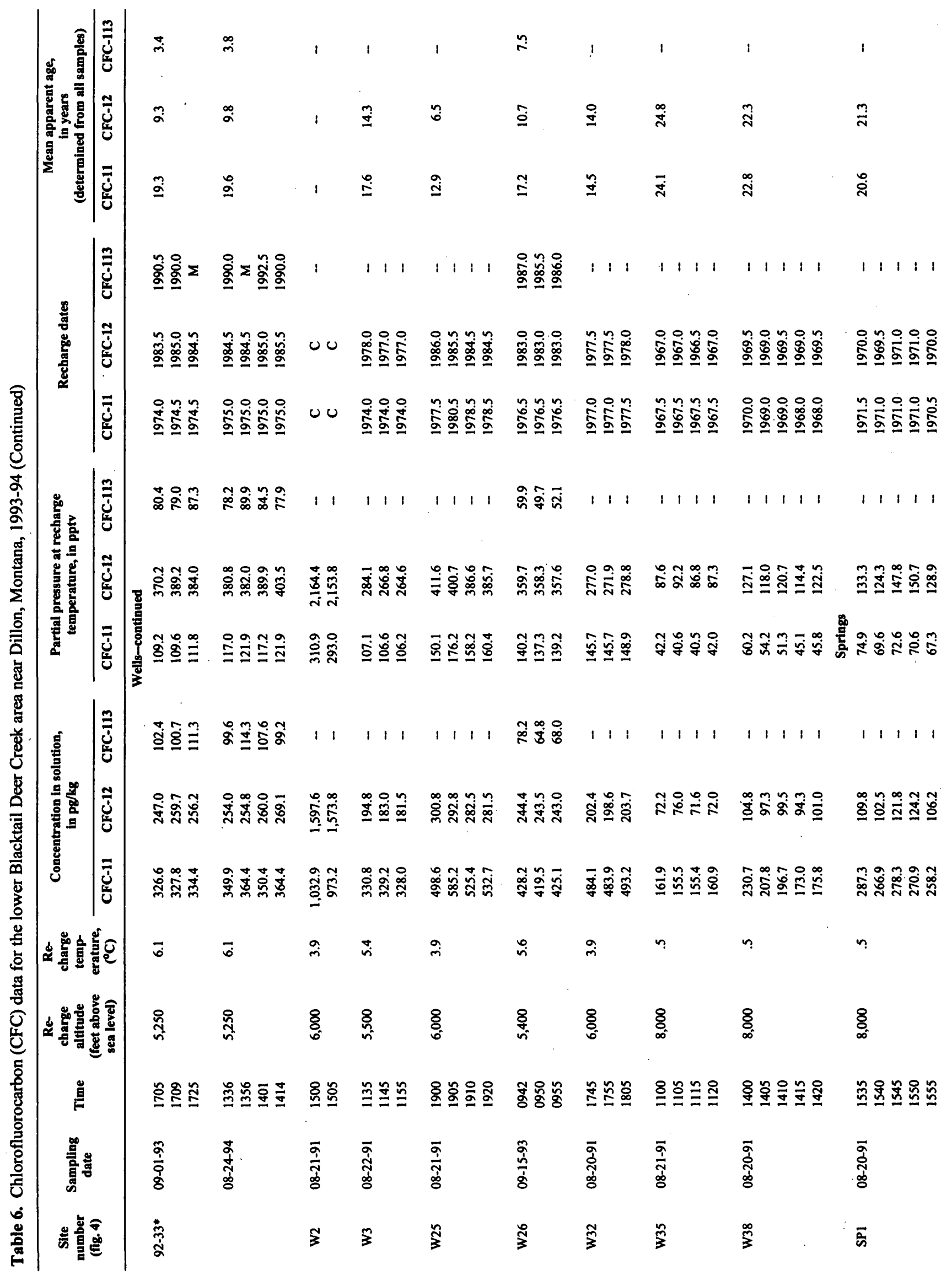




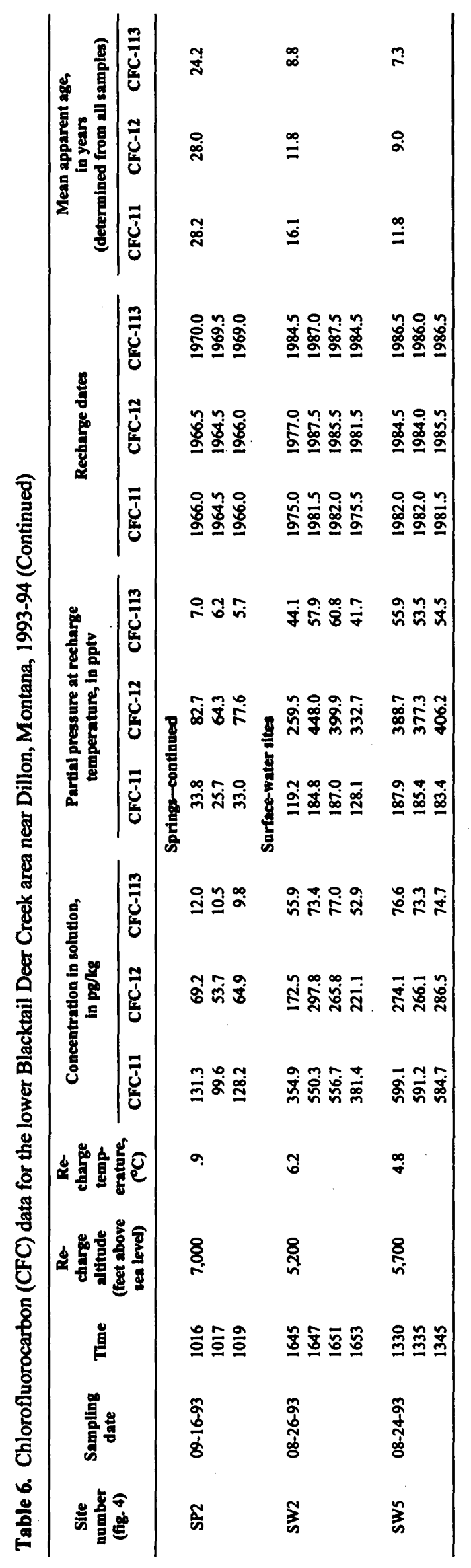


Table 7. Physical characteristics measured in wells, springs, and surface-water sites during chlorofluorocarbon (CFC) sampling in the lower Blacktail Deer Creek area near Dillon, Montana, 1991 and 1993-94

[Site number described in text. Nested well- N, no; Y, yes. Abbreviations: $\mu \mathrm{S} / \mathrm{cm}$, microsiemens per centimeter at $25^{\circ} \mathrm{C}$; ${ }^{\circ} \mathrm{C}$, degrees Celsius; $\mathrm{mg} / \mathrm{L}$, milligrams per liter; --, no data]

\begin{tabular}{|c|c|c|c|c|c|c|c|}
\hline $\begin{array}{c}\text { Site } \\
\text { number } \\
\text { (fig. 4) }\end{array}$ & Nested well & Date & Time & $\begin{array}{c}\text { Specific } \\
\text { conduct- } \\
\text { ance } \\
(\mu \mathrm{S} / \mathrm{cm})\end{array}$ & $\begin{array}{c}\text { pH } \\
\text { (standard } \\
\text { units) }\end{array}$ & $\begin{array}{l}\text { Water } \\
\text { temper- } \\
\text { ature } \\
\left({ }^{\circ} \mathrm{C}\right)\end{array}$ & $\begin{array}{c}\text { Dissolved } \\
\text { oxygen } \\
(\mathrm{mg} / \mathrm{L})\end{array}$ \\
\hline \multicolumn{8}{|c|}{ Wells } \\
\hline \multirow[t]{2}{*}{91.1} & $\mathbf{N}$ & $08-24-93$ & 1518 & 543 & 7.4 & 8.0 & 7.4 \\
\hline & & & 1522 & 543 & 7.4 & 8.0 & 7.4 \\
\hline & &. & 1525 & 544 & 7.4 & 8.1 & 7.4 \\
\hline & & & 1529 & 548 & 7.4 & 8.3 & 7.4 \\
\hline & & & 1533 & 547 & 7.4 & 8.4 & 7.4 \\
\hline & & $08-26-94$ & 1329 & 638 & 7.4 & 8.9 & 6.7 \\
\hline & & & 1333 & 640 & 7.4 & 8.6 & 6.7 \\
\hline & & & 1337 & 640 & 7.4 & 9.0 & 6.6 \\
\hline & & & 1342 & 640 & 7.4 & 8.7 & 6.6 \\
\hline & & & 1347 & 638 & 7.4 & 9.2 & 6.6 \\
\hline \multirow[t]{5}{*}{$91-2$} & $\mathbf{N}$ & $08-25-93$ & 0950 & 531 & 7.4 & 10.6 & 6.7 \\
\hline & & & 0955 & 531 & 7.3 & 10.6 & 6.7 \\
\hline & & & 1000 & 532 & 7.3 & 10.7 & 6.7 \\
\hline & & & 1012 & 533 & 7.3 & 10.8 & 6.7 \\
\hline & & & 1017 & 534 & 7.3 & 10.9 & 6.8 \\
\hline \multirow[t]{5}{*}{$91-3$} & $\mathbf{N}$ & $08-25-93$ & 1236 & 681 & 7.3 & 9.8 & 7.6 \\
\hline & & & 1242 & 681 & 7.3 & 9.8 & 7.5 \\
\hline & & & 1246 & 680 & 7.3 & 9.8 & 7.5 \\
\hline & & & 1250 & 680 & 7.3 & 9.8 & 7.5 \\
\hline & & & 1255 & 680 & 7.3 & 9.8 & 7.5 \\
\hline \multirow[t]{11}{*}{$91-4$} & $\mathbf{N}$ & $09-03-93$ & 1318 & 549 & 7.5 & 10.8 & 8.4 \\
\hline & & & 1326 & 549 & 7.5 & 10.9 & 8.4 \\
\hline & . & & 1331 & 549 & 7.5 & 11.0 & 8.4 \\
\hline & & & 1335 & 549 & 7.5 & 11.0 & 8.4 \\
\hline & & & 1341 & 549 & 7.5 & 11.0 & 8.4 \\
\hline & & & 1346 & 549 & 7.5 & 10.9 & 8.4 \\
\hline & $\therefore$ & $08-26-94$ & 1508 & 533 & 7.4 & 10.7 & 9.1 \\
\hline & & & 1514 & 534 & 7.4 & 10.6 & 9.1 \\
\hline & & & 1520 & 534 & 7.4 & 10.7 & 9.1 \\
\hline & r & & 1524 & 535 & 7.4 & 10.7 & 9.1 \\
\hline & & & 1529 & 535 & 7.4 & 10.7 & 9.1 \\
\hline \multirow[t]{5}{*}{$91-5$} & $\mathbf{N}$ & 09-03-93 & 1117 & 650 & 7.4 & 9.3 & 8.3 \\
\hline & & & 1123 & 650 & 7.4 & 9.3 & 8.3 \\
\hline & & & 1128 & 650 & 7.4 & 9.3 & 8.3 \\
\hline & & & 1134 & 650 & 7.4 & 9.3 & 8.3 \\
\hline & & & 1138 & 650 & 7.4 & 9.3 & 8.3 \\
\hline \multirow[t]{5}{*}{$91-6$} & $\mathbf{N}$ & 09-03-93 & 0908 & 547 & 7.6 & 8.3 & 8.5 \\
\hline & & & 0912 & 547 & 7.6 & 8.3 & 8.6 \\
\hline & & & 0917 & 547 & 7.6 & 8.3 & 8.5 \\
\hline & & & 0921 & 547 & 7.6 & 8.3 & 8.4 \\
\hline & t & & 0925 & 547 & 7.6 & 8.3 & 8.5 \\
\hline \multirow[t]{10}{*}{$91-7$} & $\mathbf{N}$ & $08-26-93$ & 1621 & 563 & 7.6 & 9.3 & 8.1 \\
\hline & & & 1624 & 563 & 7.6 & 9.3 & 8.1 \\
\hline & & & 1630 & 563 & 7.6 & 9.2 & 8.1 \\
\hline & & & 1634 & 564 & 7.6 & 9.2 & 8.1 \\
\hline & & & 1639 & 563 & 7.6 & 9.2 & 8.1 \\
\hline & & $08-25-94$ & 1746 & 559 & 7.4 & 9.2 & 8.5 \\
\hline & & & 1753 & 558 & 7.4 & 9.1 & 8.6 \\
\hline & & & 1758 & 558 & 7.4 & 9.2 & 8.6 \\
\hline & & & 1803 & 558 & 7.4 & 9.1 & 8.6 \\
\hline & & & 1808 & 558 & 7.4 & 9.2 & 8.6 \\
\hline \multirow{6}{*}{$92-1$} & $\mathbf{Y}$ & $08-24-93$ & 1150 & 640 & 7.4 & 12.8 & 4.0 \\
\hline & 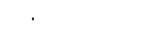 & & 1155 & 640 & 7.4 & 12.5 & 4.0 \\
\hline & & & 1200 & 640 & 7.4 & 12.0 & 4.0 \\
\hline & & & 1205 & 640 & 7.4 & 12.5 & 4.0 \\
\hline & & & 1210 & 640 & 7.4 & 11.8 & 4.0 \\
\hline & $\therefore$ & & 1215 & 641 & 7.5 & 11.8 & 4.0 \\
\hline \multirow[t]{10}{*}{$92-2$} & $\mathbf{Y}$ & $08-24-93$ & 0933 & 566 & 7.4 & 9.5 & 1.6 \\
\hline & & & 0958 & 566 & 7.4 & 9.6 & 1.6 \\
\hline & & & 1003 & 566 & 7.4 & 9.5 & 1.6 \\
\hline & & & 1007 & 566 & 7.4 & 9.6 & 1.6 \\
\hline & & & 1012 & 566 & 7.4 & 9.7 & 1.6 \\
\hline & & $08-26-94$ & 1132 & 562 & 7.3 & 9.5 & 1.6 \\
\hline & & & 1136 & 562 & 7.3 & 9.5 & 1.7 \\
\hline & & & 1141 & 562 & 7.3 & 9.6 & 1.7 \\
\hline & & & 1152 & 562 & 7.3 & 9.9 & 1.7 \\
\hline & & & 1158 & 562 & 7.3 & 9.7 & 1.7 \\
\hline
\end{tabular}


Table 7. Physical characteristics measured in wells, springs, and surface-water sites during chlorofluorocarbon (CFC) sampling in the lower Blacktail Deer Creek area near Dillon, Montana, 1991 and 1993-94

(Continued)

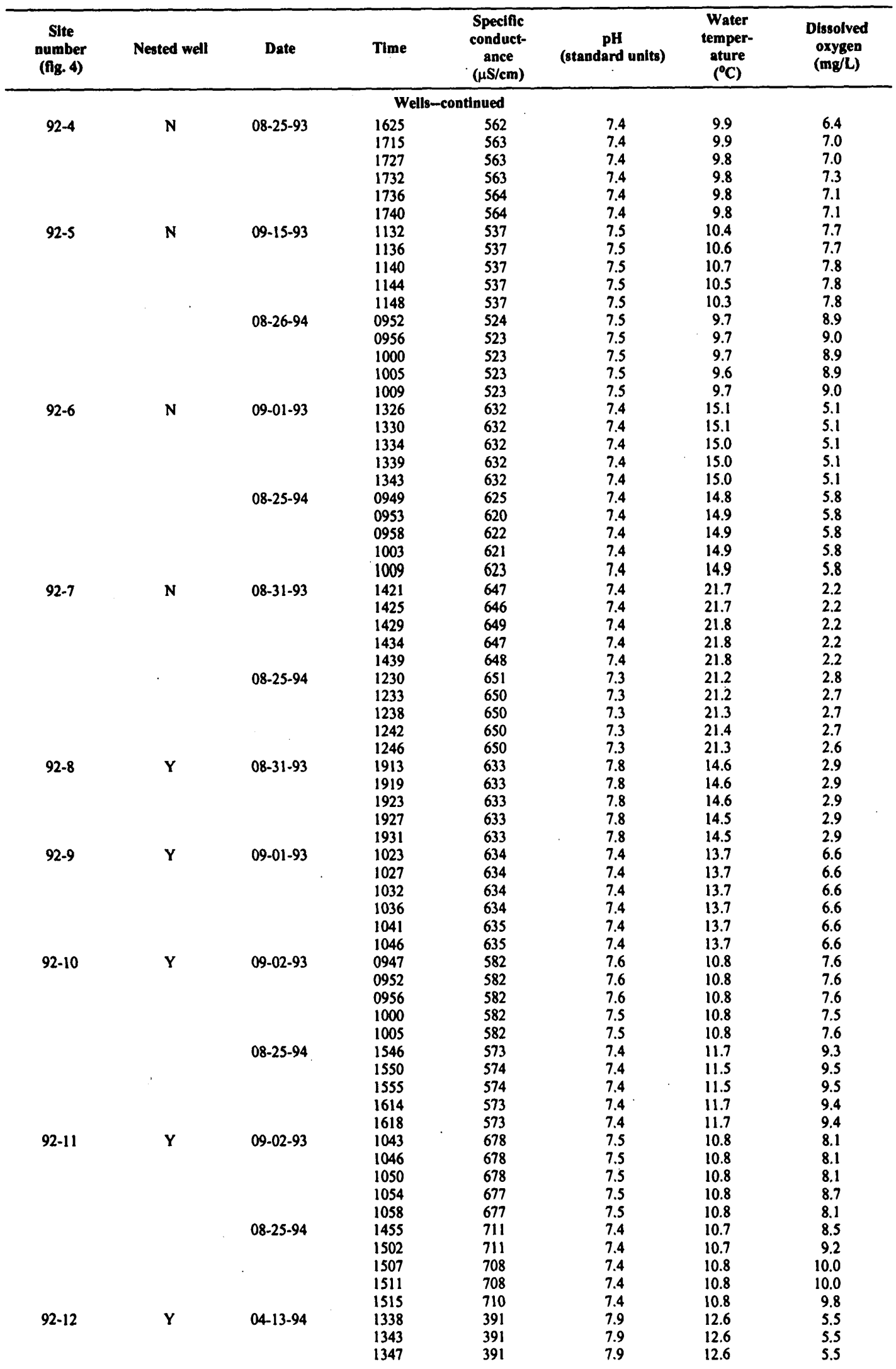


Table 7. Physical characteristics measured in wells, springs, and surface-water sites during chlorofluorocarbon (CFC) sampling in the lower Blacktail Deer Creek area near Dillon, Montana, 1991 and 1993-94 (Continued)

\begin{tabular}{|c|c|c|c|c|c|c|c|}
\hline $\begin{array}{c}\text { Site } \\
\text { number } \\
\text { (fig. 4) }\end{array}$ & Nested well & Date & Time & $\begin{array}{c}\text { Specific } \\
\text { conduct- } \\
\text { ance } \\
(\mu \mathrm{S} / \mathrm{cm})\end{array}$ & $\underset{\text { (standard units) }}{\mathrm{pH}}$ & $\begin{array}{c}\text { Water } \\
\text { temper- } \\
\text { ature } \\
\left({ }^{\circ} \mathrm{C}\right)\end{array}$ & $\begin{array}{c}\text { Dissolved } \\
\text { oxygen } \\
(\mathrm{mg} / \mathrm{L})\end{array}$ \\
\hline \multicolumn{8}{|c|}{ Wells-continued } \\
\hline & & & 1353 & 391 & 7.9 & 12.7 & 5.5 \\
\hline & & & 1357 & 391 & 7.9 & 12.7 & 5.5 \\
\hline \multirow[t]{6}{*}{$92-13$} & $\mathbf{Y}$ & $04-13-94$ & 1558 & 640 & 7.5 & 10.4 & 6.2 \\
\hline & & & 1607 & 640 & 7.5 & 10.3 & 6.2 \\
\hline & & & 1611 & 640 & 7.5 & 10.4 & 6.2 \\
\hline & & & 1616 & 640 & 7.5 & 10.4 & 6.2 \\
\hline & & & 1620 & 640 & 7.5 & 10.3 & 6.2 \\
\hline & & & 1626 & 640 & 7.5 & 10.3 & 6.2 \\
\hline \multirow[t]{6}{*}{92.14} & $\mathbf{N}$ & $04-14-94$ & 1341 & 563 & 7.4 & 8.3 & 7.3 \\
\hline & & & 1348 & 563 & 7.4 & 8.3 & 7.3 \\
\hline & & & 1355 & 563 & 7.4 & 8.3 & 7.3 \\
\hline & & & 1401 & 563 & 7.4 & 8.3 & 7.3 \\
\hline & & . & 1406 & 563 & 7.4 & 8.3 & 7.3 \\
\hline & & & 1411 & 563 & 7.4 & 8.3 & 7.3 \\
\hline \multirow[t]{5}{*}{$92-15$} & $\mathbf{N}$ & $04-14-94$ & 1056 & 386 & 7.4 & 12.9 & 6.1 \\
\hline & & & 1101 & 386 & 7.4 & 12.9 & 6.1 \\
\hline & & & 1109 & 386 & 7.4 & 12.9 & 6.2 \\
\hline & & & 1116 & 386 & 7.4 & 13.0 & 6.2 \\
\hline & & & 1124 & 386 & 7.4 & 13.0 & 6.2 \\
\hline \multirow[t]{10}{*}{$92-16$} & $\mathbf{N}$ & $08-27-93$ & 1707 & 531 & 7.5 & 11.0 & 4.8 \\
\hline & & & 1711 & 531 & 7.5 & 11.0 & 4.8 \\
\hline & & & 1720 & 531 & 7.5 & 11.1 & 4.8 \\
\hline & & & 1725 & 531 & 7.5 & 11.1 & 4.9 \\
\hline & & & 1729 & 531 & 7.5 & 11.0 & 4.9 \\
\hline & & $08-23-94$ & 1724 & 521 & 7.5 & 11.2 & 4.1 \\
\hline & & & 1728 & 521 & 7.5 & 11.1 & 4.1 \\
\hline & & & 1735 & 521 & 7.5 & 11.2 & 3.9 \\
\hline & & & 1739 & 521 & 7.5 & 10.9 & 4.0 \\
\hline & & & 1745 & 521 & 7.5 & 10.9 & 4.0 \\
\hline \multirow[t]{10}{*}{$92-17$} & $\mathbf{Y}$ & $08-23-93$ & 1930 & 504 & 7.8 & 12.3 & 5.4 \\
\hline & & & 1935 & 504 & 7.8 & 12.3 & 5.4 \\
\hline & & & 1940 & 504 & 7.8 & 12.3 & 5.4 \\
\hline & & & 1950 & 503 & 7.8 & 12.0 & 5.4 \\
\hline & & & 2000 & 504 & 7.8 & 11.9 & 5.4 \\
\hline & & $08-23-94$ & 1533 & 492 & 7.8 & 12.4 & 4.9 \\
\hline & & & 1539 & 492 & 7.8 & 12.5 & 5.0 \\
\hline & & & 1546 & 492 & 7.8 & 12.5 & 5.2 \\
\hline & & & 1558 & 492 & 7.7 & 12.5 & 5.2 \\
\hline & & & 1604 & 492 & 7.7 & 12.5 & 5.2 \\
\hline \multirow[t]{11}{*}{$92-18$} & $\mathrm{Y}$ & $08-23-93$ & 1605 & - & - & -- & - \\
\hline & & & 1700 & 694 & 7.4 & 11.5 & 3.2 \\
\hline & & & 1706 & 693 & 7.4 & 11.1 & 3.3 \\
\hline & & & 1711 & 692 & 7.4 & 11.3 & 3.3 \\
\hline & & & 1718 & 689 & 7.6 & 11.3 & 3.4 \\
\hline & & & 1724 & 688 & 7.6 & 11.4 & 3.4 \\
\hline & & $08-23-94$ & 1220 & 650 & 7.5 & 10.8 & 4.6 \\
\hline & & & 1225 & 650 & 7.5 & 10.8 & 4.5 \\
\hline & & & 1236 & 650 & 7.5 & 10.8 & 4.5 \\
\hline & & & 1240 & 650 & 7.5 & 10.8 & 4.5 \\
\hline & & & 1248 & 651 & 7.5 & 10.9 & 4.5 \\
\hline \multirow[t]{10}{*}{$92-19$} & $\mathrm{Y}$ & $08-26-93$ & 1125 & 583 & 7.6 & 10.0 & 5.8 \\
\hline & & & 1129 & 584 & 7.6 & 10.0 & 5.8 \\
\hline & & & 1132 & 583 & 7.6 & 10.0 & 5.8 \\
\hline & & & 1135 & 583 & 7.6 & 10.0 & 5.8 \\
\hline & & & 1140 & 583 & 7.6 & 10.0 & 5.8 \\
\hline & & $08-24-94$ & 1047 & 575 & 7.5 & 9.7 & 6.1 \\
\hline & & & 1051 & 575 & 7.5 & 9.7 & 6.1 \\
\hline & & & 1058 & 575 & 7.5 & 9.6 & 6.1 \\
\hline & & & 1102 & 575 & 7.5 & 9.6 & 6.1 \\
\hline & & & 1108 & 575 & 7.5 & 9.6 & 6.1 \\
\hline $92-20$ & $\mathbf{Y}$ & $08-26-93$ & 1254 & 720 & 7.4 & 9.4 & 2.6 \\
\hline & & & 1258 & 720 & 7.4 & 9.5 & 2.6 \\
\hline & & & 1303 & 720 & 7.4 & 9.4 & 2.6 \\
\hline & & & 1307 & 720 & 7.4 & 9.4 & 2.7 \\
\hline & & & 1311 & 720 & 7.4 & 9.4 & 2.7 \\
\hline & & $08-24-94$ & 0908 & 689 & 7.3 & 9.0 & 4.9 \\
\hline & & & 0913 & 689 & 7.3 & 9.0 & 4.9 \\
\hline & & & 0921 & 688 & 7.3 & 9.1 & 4.9 \\
\hline & & & 0926 & 688 & 7.3 & 9.2 & 4.9 \\
\hline & & & 0932 & 687 & 7.3 & 9.3 & 4.9 \\
\hline $92-21$ & $\mathrm{Y}$ & $09-02-93$ & 1521 & 479 & 7.6 & 14.4 & 6.5 \\
\hline & & & 1528 & 478 & 7.7 & 14.6 & 6.6 \\
\hline
\end{tabular}


Table 7. Physical characteristics measured in wells, springs, and surface-water sites during chlorofluorocarbon (CFC) sampling in the lower Blacktail Deer Creek area near Dillon, Montana, 1991 and 1993-94 (Continued)

\begin{tabular}{|c|c|c|c|c|c|c|c|}
\hline $\begin{array}{c}\text { Site } \\
\text { number } \\
\text { (fig. 4) }\end{array}$ & Nested well & Date & Time & $\begin{array}{c}\text { Specific } \\
\text { conduct- } \\
\text { ance } \\
(\mu \mathrm{S} / \mathrm{cm})\end{array}$ & $\underset{\text { (standard units) }}{\mathrm{pH}}$ & $\begin{array}{l}\text { Water } \\
\text { temper- } \\
\text { ature } \\
\left.{ }^{\circ} \mathrm{C}\right)\end{array}$ & $\begin{array}{c}\text { Dissolved } \\
\text { oxygen } \\
(\mathrm{mg} / \mathrm{L})\end{array}$ \\
\hline \multicolumn{8}{|c|}{ Wells--continued } \\
\hline \multirow{8}{*}{$92-22$} & & & 1534 & 478 & 7.7 & 14.6 & 6.7 \\
\hline & & & 1540 & 479 & 7.7 & 14.6 & 6.7 \\
\hline & & & 1546 & 479 & 7.7 & 15.5 & 6.8 \\
\hline & $\mathbf{Y}$ & $09-02-93$ & 1415 & 629 & 7.5 & 10.9 & 7.1 \\
\hline & & & 1421 & 629 & 7.5 & 10.9 & 7.1 \\
\hline & & & 1426 & 630 & 7.5 & 10.9 & 7.1 \\
\hline & & & 1434 & 629 & 7.5 & 10.9 & 7.0 \\
\hline & & & 1441 & 629 & 7.5 & 10.9 & 7.0 \\
\hline \multirow[t]{5}{*}{$92-23$} & $\mathbf{Y}$ & $08-28-93$ & 1142 & 687 & 7.4 & 9.6 & 3.1 \\
\hline & & & 1146 & 687 & 7.4 & 9.6 & 3.1 \\
\hline & & & 1150 & 687 & 7.4 & 9.6 & 3.1 \\
\hline & & & 1154 & 686 & 7.4 & 9.6 & 3.1 \\
\hline & & & 1158 & 686 & 7.4 & 9.6 & 3.1 \\
\hline \multirow[t]{5}{*}{$92-24$} & $\mathbf{Y}$ & $08-28-93$ & 1313 & 771 & 7.3 & 9.6 & 5.6 \\
\hline & & & 1317 & 771 & 7.3 & 9.6 & 5.6 \\
\hline & & & 1321 & 771 & 7.3 & 9.6 & 5.6 \\
\hline & & & 1325 & 771 & 7.3 & 9.6 & 5.6 \\
\hline & & & 1328 & 772 & 7.3 & 9.5 & 5.6 \\
\hline \multirow[t]{5}{*}{$92-25$} & $\mathbf{N}$ & $09-14-93$ & 1917 & 645 & 7.8 & 9.3 & 5.1 \\
\hline & & & 1921 & 646 & 7.8 & 9.3 & 5.1 \\
\hline & & & 1925 & 644 & 7.8 & 9.2 & 5.2 \\
\hline & & & 1929 & 644 & 7.8 & 9.3 & 5.2 \\
\hline & & & 1933 & 645 & 7.8 & 9.2 & 5.2 \\
\hline \multirow[t]{5}{*}{$92-26$} & $\mathbf{N}$ & $09-14-93$ & 1504 & 764 & 7.6 & 10.2 & 5.6 \\
\hline & & & 1512 & 764 & 7.6 & 10.2 & 5.6 \\
\hline & & & 1517 & 766 & 7.6 & 10.6 & 5.5 \\
\hline & & & 1520 & 765 & 7.6 & 10.5 & 5.5 \\
\hline & & & 1524 & 765 & 7.6 & 10.4 & 5.5 \\
\hline \multirow[t]{5}{*}{$92-27$} & $\mathrm{~N}$ & $09-14-93$ & 1720 & 294 & 7.6 & 9.1 & 3.7 \\
\hline & & & 1727 & 294 & 7.6 & 9.0 & 3.7 \\
\hline & . & $\cdot$ & 1732 & 294 & 7.6 & 9.0 & 3.7 \\
\hline & & & 1736 & 294 & 7.6 & 8.9 & 3.7 \\
\hline & & & 1740 & 294 & 7.6 & 8.9 & 3.7 \\
\hline \multirow[t]{5}{*}{$92-28$} & $\mathbf{Y}$ & $08-27-93$ & 1046 & 501 & 7.8 & 10.0 & 3.4 \\
\hline & & & 1049 & 500 & 7.8 & 10.0 & 3.4 \\
\hline & & & 1053 & 499 & 7.8 & 10.0 & 3.4 \\
\hline & & & 1056 & 503 & 7.8 & 10.0 & 3.5 \\
\hline & & & 1100 & 505 & 7.8 & 10.1 & 3.6 \\
\hline \multirow[t]{5}{*}{$92-29$} & $\mathbf{Y}$ & $08-27-93$ & 1201 & 673 & 7.4 & 10.0 & 2.7 \\
\hline & & & 1205 & 673 & 7.4 & 10.0 & 2.7 \\
\hline & & & 1211 & 673 & 7.4 & 10.0 & 2.7 \\
\hline & & & 1215 & 673 & 7.4 & 10.1 & 2.7 \\
\hline & & & 1220 & 673 & 7.4 & 10.0 & 2.7 \\
\hline $92-30$ & $\mathbf{N}$ & $09-15-93$ & 1331 & 718 & 7.2 & 11.8 & $<.1$ \\
\hline & & & 1337 & 718 & 7.2 & 11.7 & $<.1$ \\
\hline & & & 1342 & 718 & 7.2 & 11.5 & $<.1$ \\
\hline & & & 1346 & 718 & 7.2 & 11.8 & $<.1$ \\
\hline & & & 1350 & 718 & 7.2 & 11.8 & $<.1$ \\
\hline $92-32$ & $\mathrm{Y}$ & $09-01-93$ & 1750 & 523 & 7.6 & 10.3 & 2.5 \\
\hline & & & 1754 & 523 & 7.6 & 10.3 & 2.5 \\
\hline & & & 1759 & 523 & 7.6 & 10.3 & 2.5 \\
\hline & & & 1803 & 523 & 7.7 & 10.3 & 2.4 \\
\hline & & & 1807 & 523 & 7.7 & 10.3 & 2.4 \\
\hline & & $08-24-94$ & 1527 & 522 & 7.6 & 11.2 & 2.3 \\
\hline & & & 1533 & 522 & 7.5 & 11.1 & 2.3 \\
\hline & & & 1541 & 522 & 7.6 & 10.8 & 2.3 \\
\hline & & & 1548 & 522 & 7.6 & 11.1 & 2.3 \\
\hline & & & 1552 & 522 & 7.6 & 11.0 & 2.3 \\
\hline $92-33$ & $\mathrm{Y}$ & $09-01-93$ & 1705 & 543 & 7.5 & 13.8 & 1.7 \\
\hline & & & 1709 & 543 & 7.5 & 13.7 & 1.8 \\
\hline & & & 1717 & 548 & 7.5 & 13.4 & 1.8 \\
\hline & & & 1721 & 548 & 7.5 & 13.3 & 1.8 \\
\hline & & & 1725 & 548 & 7.5 & 13.3 & 1.8 \\
\hline & & $08-24-94$ & 1331 & 564 & 7.4 & 15.1 & 2.5 \\
\hline & & & 1336 & 564 & 7.4 & 15.1 & 2.5 \\
\hline & & & 1356 & 564 & 7.4 & 15.2 & 2.5 \\
\hline & & & 1401 & 564 & 7.4 & 15.2 & 2.5 \\
\hline & & & 1414 & 563 & 7.4 & 15.0 & 2.6 \\
\hline W2 & $\mathrm{N}$ & $08-21-91$ & 1500 & 719 & 7.2 & 9.0 & 6.6 \\
\hline & & & 1505 & 719 & 7.2 & 9.0 & 6.6 \\
\hline
\end{tabular}


Table 7. Physical characteristics measured in wells, springs, and surface-water sites during chlorofluorocarbon (CFC) sampling in the lower Blacktail Deer Creek area near Dillon, Montana, 1991 and 1993-94

(Continued)

\begin{tabular}{|c|c|c|c|c|c|c|c|}
\hline $\begin{array}{c}\text { Site } \\
\text { number } \\
\text { (fig. 4) }\end{array}$ & Nested well & Date & Time & $\begin{array}{c}\text { Specific } \\
\text { conduct- } \\
\text { ance } \\
(\mu \mathrm{S} / \mathrm{cm})\end{array}$ & $\begin{array}{c}\mathrm{pH} \\
\text { (standard units) }\end{array}$ & $\begin{array}{l}\text { Water } \\
\text { temper- } \\
\text { ature } \\
\text { ('C) }\end{array}$ & $\begin{array}{c}\text { Dissolved } \\
\text { oxygen } \\
\text { (mg/L) }\end{array}$ \\
\hline \multicolumn{8}{|c|}{ Wells--continued } \\
\hline W3 & $\mathbf{N}$ & $08-22-91$ & $\begin{array}{l}1510 \\
1515 \\
1520 \\
1135 \\
1140 \\
1145 \\
1150 \\
1155\end{array}$ & $\begin{array}{l}719 \\
719 \\
719 \\
700 \\
700 \\
700 \\
700 \\
700\end{array}$ & $\begin{array}{l}7.2 \\
7.2 \\
7.2 \\
7.3 \\
7.3 \\
7.3 \\
7.3 \\
7.3\end{array}$ & $\begin{array}{l}9.0 \\
9.0 \\
9.0 \\
9.5 \\
9.5 \\
9.5 \\
9.5 \\
9.5\end{array}$ & $\begin{array}{l}6.6 \\
6.6 \\
6.6 \\
2.8 \\
2.8 \\
2.8 \\
2.8 \\
2.8\end{array}$ \\
\hline W25 & $\mathbf{N}$ & $08-21-91$ & 1900 & 517 & 7.5 & 8.4 & 10.8 \\
\hline \multirow[t]{4}{*}{ W26 } & $\mathbf{N}$ & $09-15-93$ & $\begin{array}{l}0939 \\
0942\end{array}$ & $\begin{array}{l}647 \\
649\end{array}$ & $\begin{array}{l}7.4 \\
7.5\end{array}$ & $\begin{array}{l}11.3 \\
11.3\end{array}$ & $\begin{array}{l}7.0 \\
7.0\end{array}$ \\
\hline & & & 0946 & 648 & 7.5 & 11.3 & 7.0 \\
\hline & & & 0950 & 647 & 7.5 & 11.3 & 7.0 \\
\hline & & & 0955 & 650 & 7.5 & 11.3 & 7.0 \\
\hline \multirow[t]{5}{*}{ W32 } & $\mathbf{N}$ & $08-20-91$ & 1745 & 519 & 7.4 & 9.6 & 9.5 \\
\hline & & & 1750 & 519 & 7.4 & 9.6 & 9.5 \\
\hline & & & 1755 & 519 & 7.4 & 9.6 & 9.5 \\
\hline & & & 1800 & 519 & 7.4 & 9.6 & 9.5 \\
\hline & & & 1805 & 519 & 7.4 & 9.6 & 9.5 \\
\hline \multirow[t]{5}{*}{ W35 } & $\mathbf{N}$ & $08-21-91$ & 1100 & 614 & 7.4 & 12.5 & 7.3 \\
\hline & & & 1105 & 614 & 7.4 & 12.5 & 7.3 \\
\hline & & & 1110 & 614 & 7.4 & 12.5 & 7.3 \\
\hline & & & 1115 & 614 & 7.4 & 12.5 & 7.3 \\
\hline & & & 1120 & 614 & 7.4 & 12.5 & 7.3 \\
\hline \multirow[t]{5}{*}{ W38 } & $\mathbf{N}$ & $08-20-91$ & 1400 & 640 & 7.4 & 22.1 & 4.8 \\
\hline & & . & 1405 & 640 & 7.4 & 22.1 & 4.8 \\
\hline & & & 1410 & 640 & 7.4 & 22.1 & 4.8 \\
\hline & & & 1415 & 640 & 7.4 & 22.1 & 4.8 \\
\hline & & & 1420 & 640 & 7.4 & 22.1 & 4.8 \\
\hline \multicolumn{8}{|c|}{ Springs } \\
\hline SP1 & $\mathbf{N}$ & $08-20-91$ & 1535 & 660 & 7.4 & 20.5 & 3.8 \\
\hline & & & 1540 & 660 & 7.4 & 20.5 & 3.8 \\
\hline & & & 1545 & 660 & 7.4 & 20.5 & 3.8 \\
\hline . & & & 1550 & 660 & 7.4 & 20.5 & 3.8 \\
\hline & & & 1555 & 660 & 7.4 & 20.5 & 3.8 \\
\hline SP2 & $\mathbf{N}$ & $09-16-93$ & 1015 & 274 & 7.8 & 6.5 & 6.8 \\
\hline \multicolumn{8}{|c|}{ Surface-water sites } \\
\hline sw2 & $\mathbf{N}$ & $08-26-94$ & 1345 & 900 & 7.9 & 13.0 & 10.5 \\
\hline SW3 & $\mathrm{N}$ & $08-25-93$ & 1830 & 503 & 8.8 & 14.5 & 8.6 \\
\hline SW5 & $\mathbf{N}$ & $08-24-93$ & 1330 & 517 & 8.4 & 13.0 & 9.4 \\
\hline
\end{tabular}




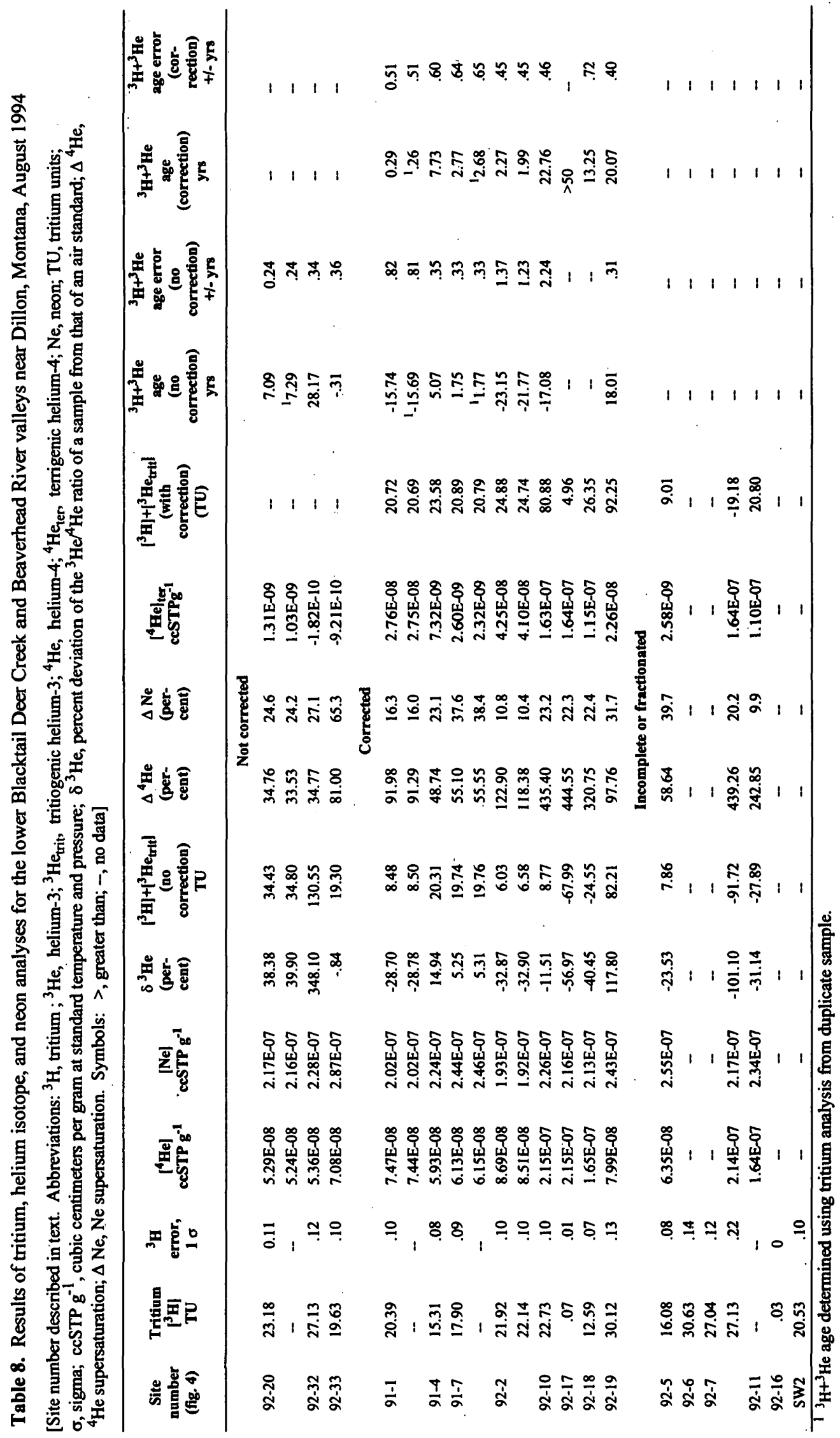

